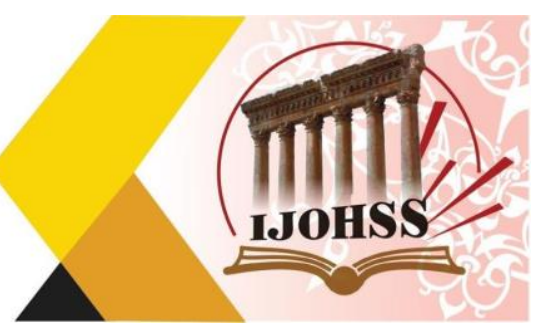

\title{
الإقرار القضائي وأثره على سير الدعوى المدنية

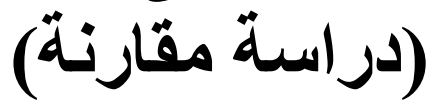

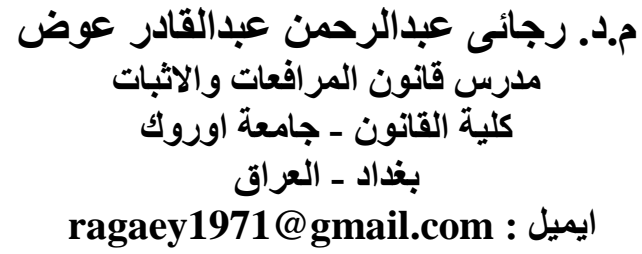

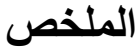

تهدف هذه الدر اسة إلى تعريف الإقرار القضائى وتمييزه عن غيره من أدلة الاثبات الأخرى كالثشهادة والدليل

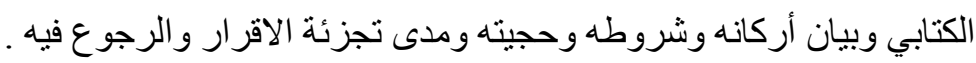

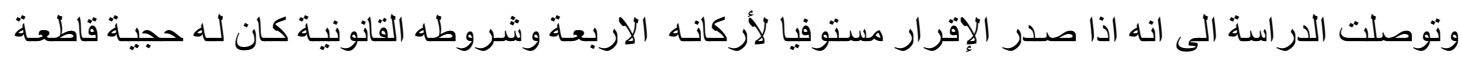
وقاصرة على المقر وورثته من بعده ، و لا يجوز الرجوع في الإقرار القضـائي، ولا تجزئته إلا إذا انصب على لهـ

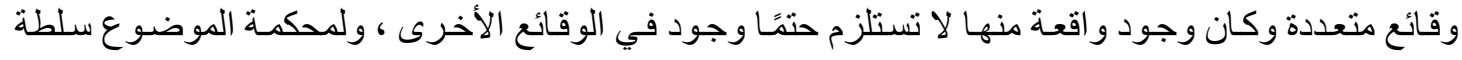

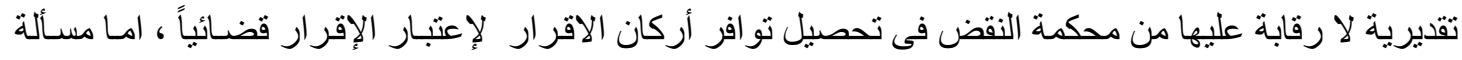

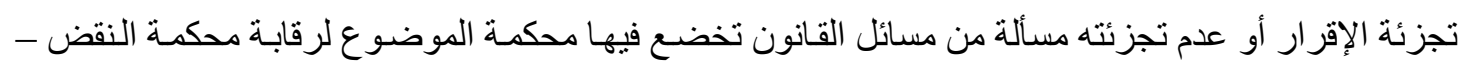
التمييز فإذا جزأت محكمة الموضوع إقرارًا لا تصح تجزئته أو رفضت إقرار تصح تجزئته كان حكمها غير سليم ويجب نقضه . وتقدم نصاً قانونياً مقترحاً يتضمن ـ تعديل المادة 1/104 من قانون الإثبات المصري ليكون الإقرار حجـة قاطعة وقاصرة على المقر لأن الجمع بين الحجية القاطعة والقاصرة أفضل ويستوجب التأييد ، وكذلك اضـافة فقرة ثانيـة الى ذات المادة وهى و لا يصح الرجوع عن الإقرار إلا لغلط جوهري ـ لـ لئ

الكلمات المفتاحية: الإقرار القضائي،حجية قاطعة وقاصرة، سلطة المحكمة، الدعوى المدنية. 


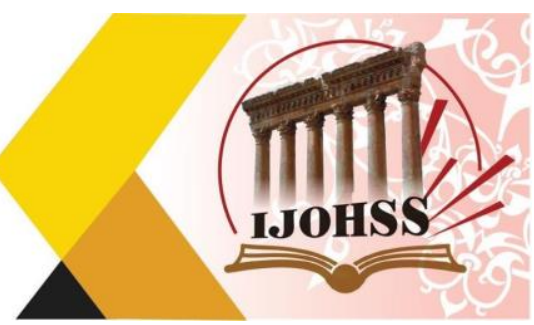

\title{
Judicial Recognition and its Impact on the Conduct of the Civil Action (A comparative study)
}

\author{
Dr. Ragaey Abdulrahman Abdulkader Awad \\ College of Law - Uruk University \\ Baghdad - Iraq \\ Email: ragaey1971@gmail.com
}

\begin{abstract}
This study aims to define the judicial declaration and distinguish it from other evidence such as testimony, written evidence, statement of its pillars, conditions and authority, and the extent of the fragmentation of the declaration and its reference .

The study concluded that if the declaration was issued in accordance with its four pillars and legal conditions, it had a firm authority and limited to the headquarters and its heirs after it, and it is not permissible to refer to the judicial declaration, and not to break it up unless it is focused on multiple facts and the existence of an incident of which does not require the existence of other facts, and the court of the subject has authority Estimate not controlled by the Court of Cassation in collecting the availability of the pillars of the declaration for consideration of the declaration judicially, either the issue of the fragmentation or non-fragmentation of a matter of law in which the court of the trial is subject to the control of the Court of Cassation discrimination, if the court of the subject breaks a declaration that is not valid for its fragmentation or refuses to approve its fragmentation, its ruling was incorrect and must be overturned .

It submits a proposed legal text that includes - amending article 104/1 of the Egyptian evidentiary law to make the declaration a definitive and limited argument to headquarters because the combination of the definitive and minor authenticity is better and requires support, as well as adding a second paragraph to the same article, which is not valid to refer to the declaration except for a fundamental error.
\end{abstract}

Keywords: Judicial confirmation, conclusive and inadequate argument, court authority, civil action. 
أغسطس 2020

العدد (14)

ISSN: $2415-\mathbf{4 8 2 2}$

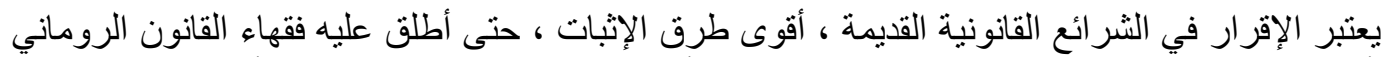

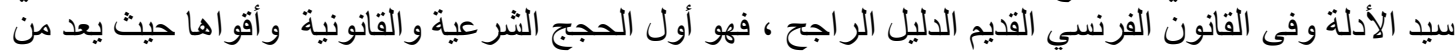

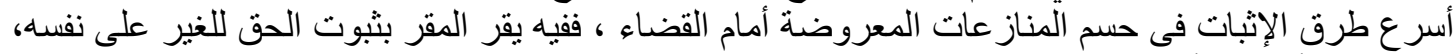

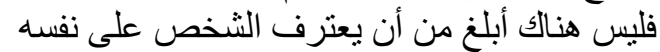

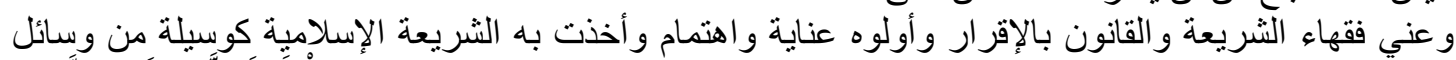

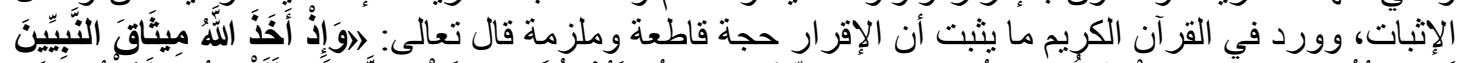

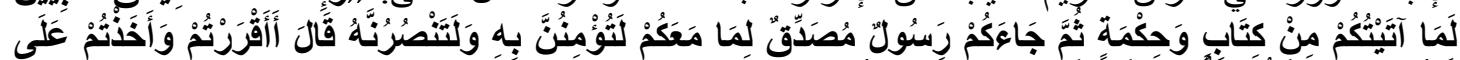

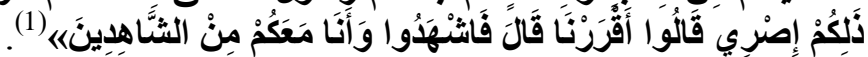

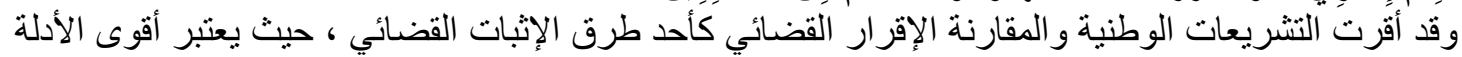

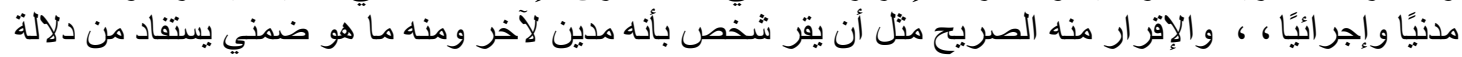

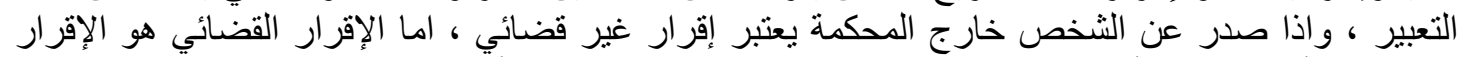

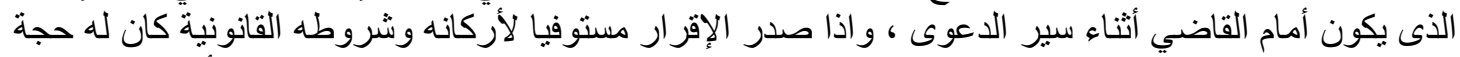

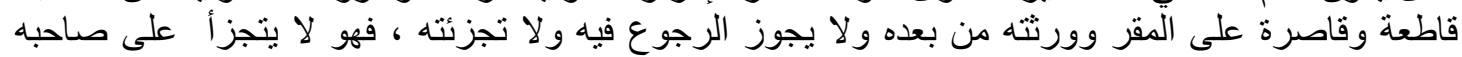

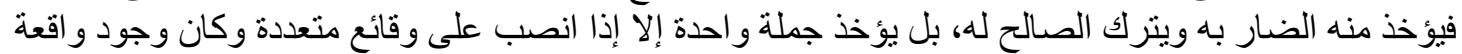

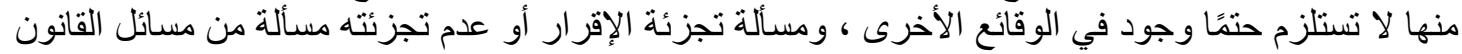

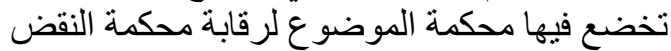

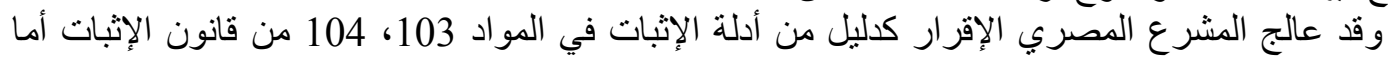

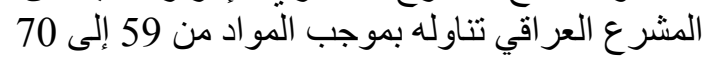
موضوع الارزاسة وأهميته:

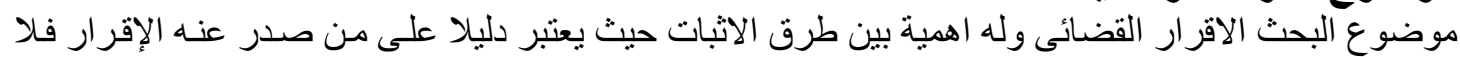

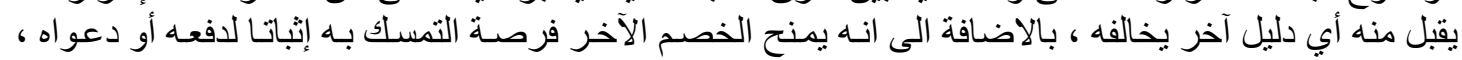

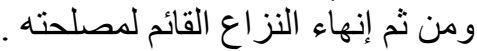

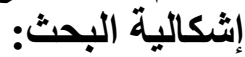
وتتمثل اثنكالية البحث فى ندرة الابحاث التى كتبت فى الاقرار ، بالإضافة الى ان هناك تساؤلات عدة سيتم

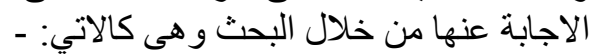

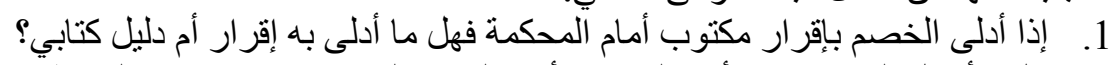

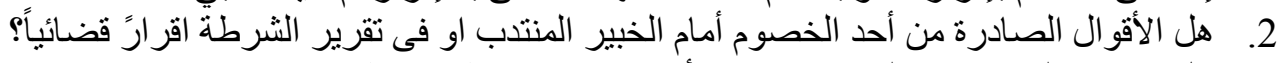

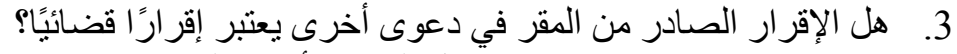

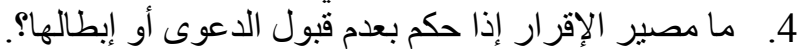

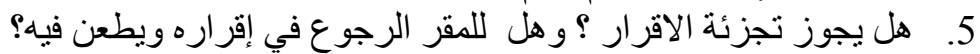

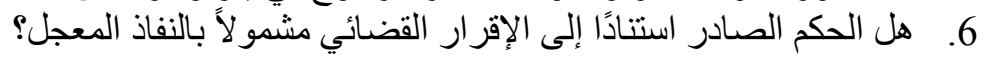

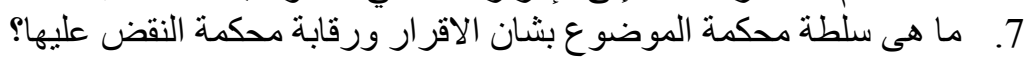
حدود البحث يقتصر نطاق البحث على دراسة الاقر ار القضائي و أثره على سير الدعوى المدنية من حيث بيان مفهومه واركانه وحجيته ، و لا يشمل البحث الاقر ار غير القضائي ويتعلق بالقضايا المدنية دون الجنائية 
أغسطس 2020

(14) العدد (14)

ISSN: $2415-\mathbf{4 8 2 2}$

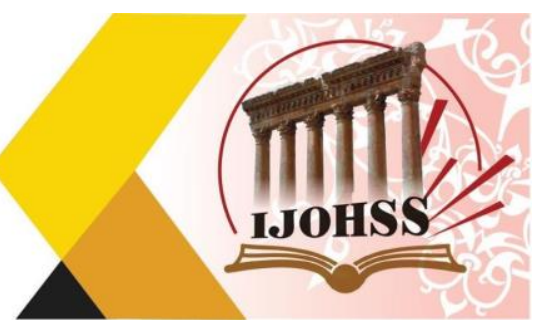

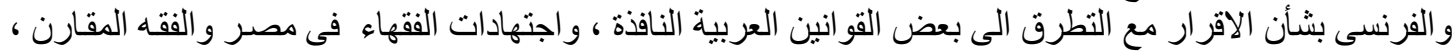

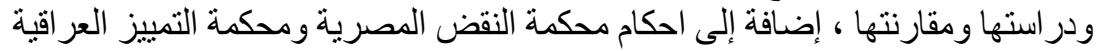

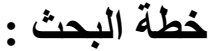

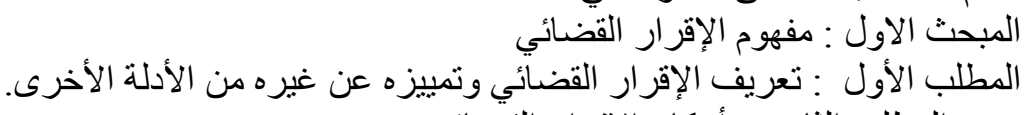
المطلب الثنانى : أركان الإقرار القضائي الإني المطلب الثالث : شروط الإقرار القضائي.

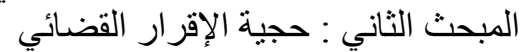

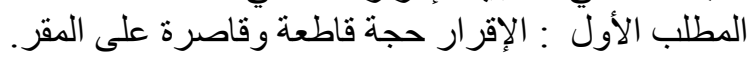

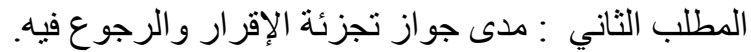

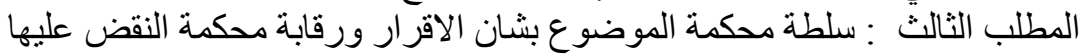
الخاتمة وتتضمن الهم النتائج و التوصيات

\author{
المبحث الاول \\ مفهوم الإقرار القضائي
}

يقتضي بيان مفهوم الإقرار القضائي الوقوف على تعريف الإقرار القضائي ومعرفة اهم ما يميزه عما يشتبه به القابه

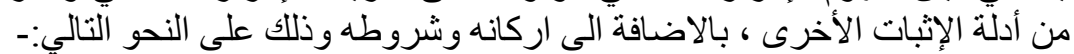
المطلب الأول : تعريف الإقرار القضائي وتمييزه عن غيره من الأدلة الإنة الأخرى. المطلب الثنانى : أركان الإقرار القضارئي الإني

\title{
المطلب الأول
}

\section{تعريف الإقرار القضائي وتمبيزه عن غيره من الأبرل الأدلة الأخرى}

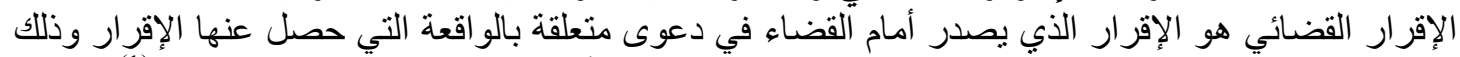

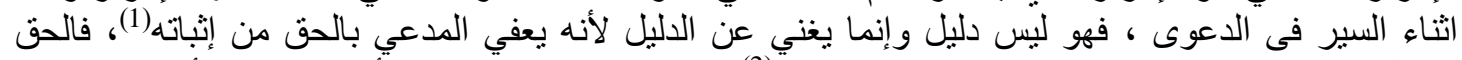

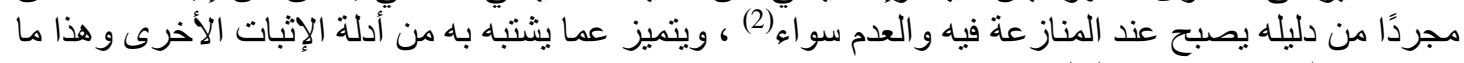
سوف نتناوله في فر ديله بصن كالتالي:

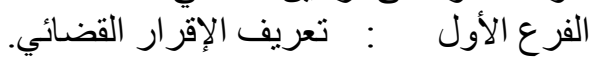
الفرع الثاني : : تمييز الإقرار القضائي عن غيرهائي من الأدلة الأخرى.

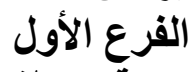
تعريف الإقرار القضائي

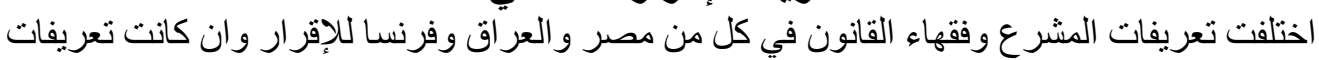

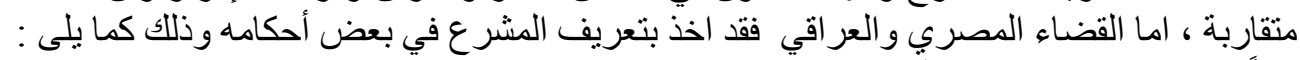
اولاً : التعريف التشريعي للإقرار الفيار

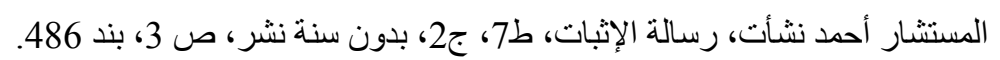

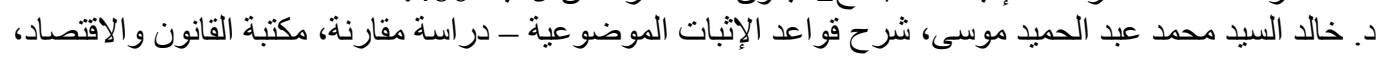

الرياض، ط 2014، ص صد 349. 


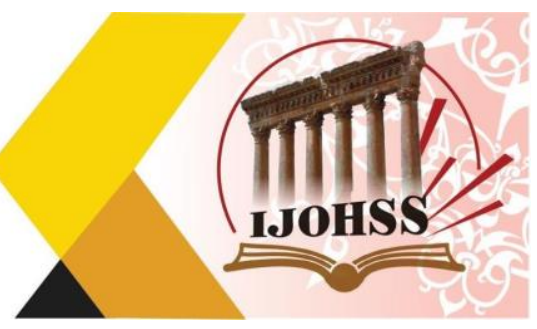

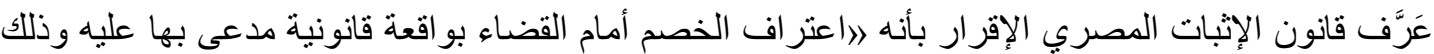

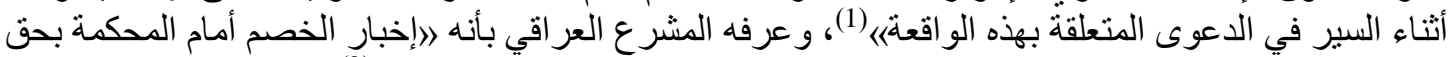

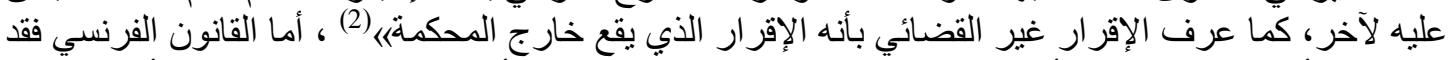

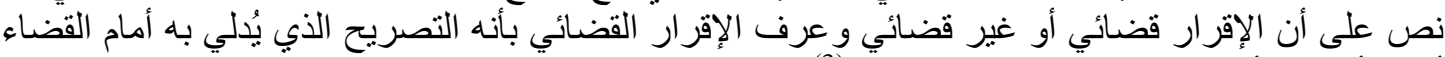

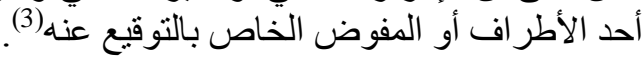

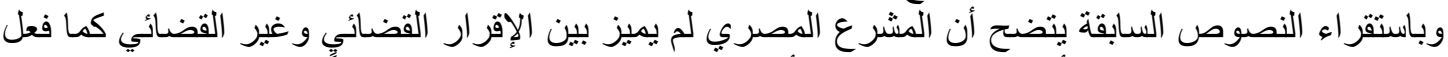

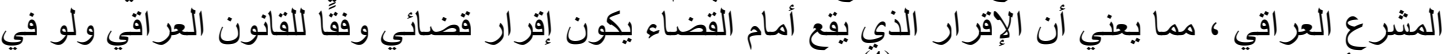

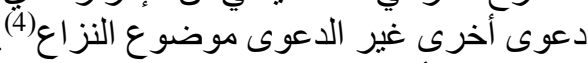

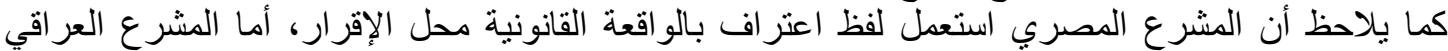

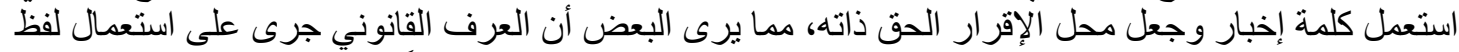

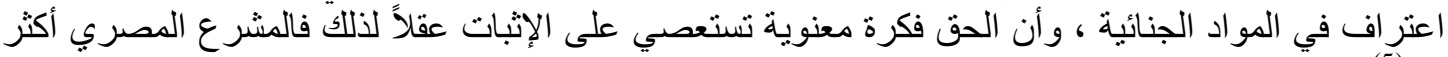

ثانياً : التعريف الفقهي للإقرار

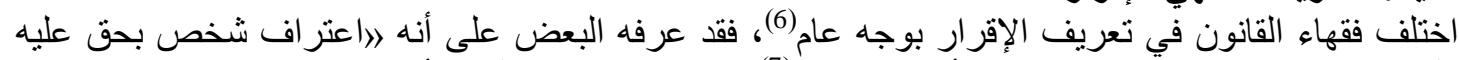

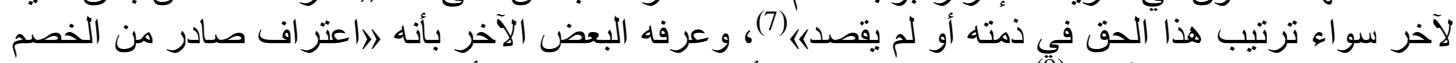

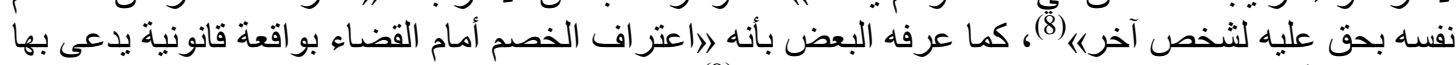

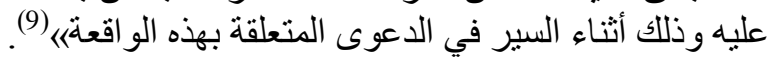

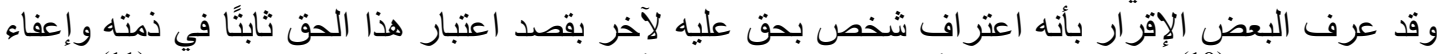

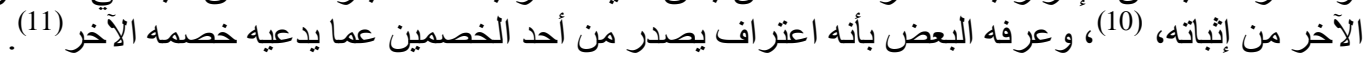

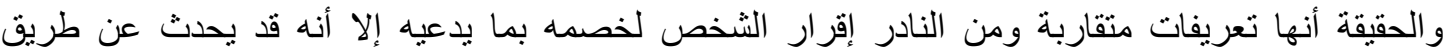

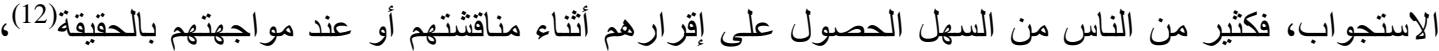

المادة 103 من قانون الإثبات المصري، وهو ذات ما نصت عليه المادة 2/51 من قانون الإثبات الإمار اتي المعدل بالقانون رقم 16 لسنة

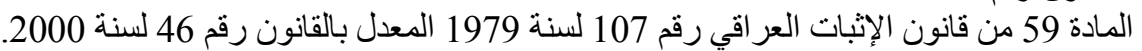

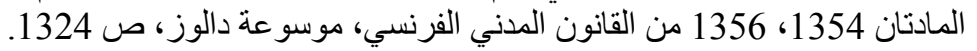

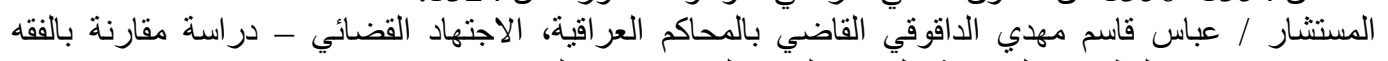

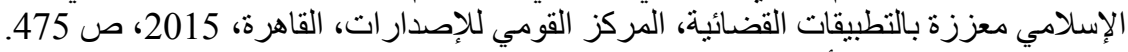

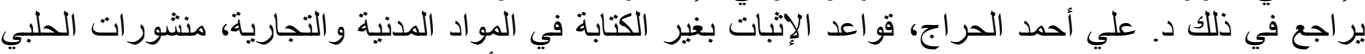

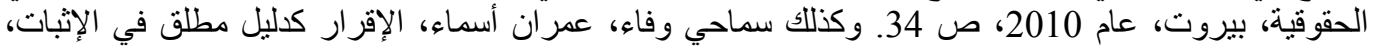
مذكرة لنيل شهادة الماستر في الحقوق، جامعة عبد الرحمن ميره، بجاية كلية الحقوق والطياه العلوم السياسية، قسم القانون

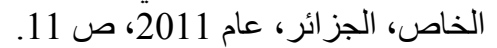

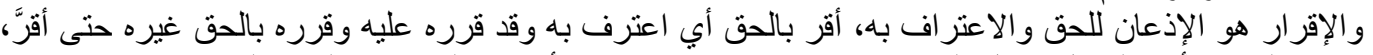

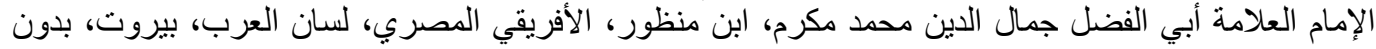

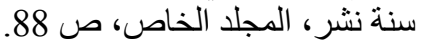

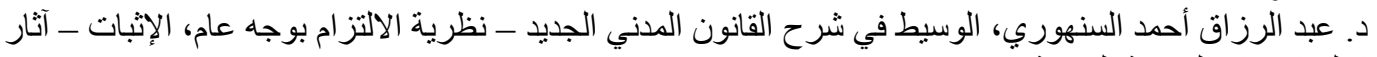

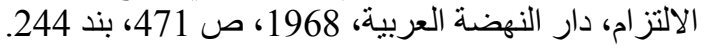

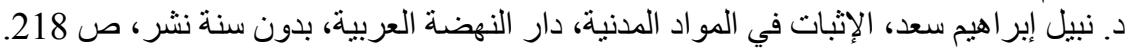

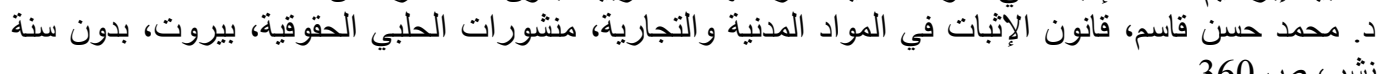
(10)د. سليمان مرقس، من طرق الإثبات الإقرار و اليمين وإجر اءاتهما في تقنينات البلاد العربية، سنة 1970، ص 3، فقرة 178 110 170 2003، صي ذلك 283. نوفيق حسن فرج، قواعد الإثبات في المواد الددنية والتجارية، منشورات الحلبي، بيروت، سنة (12) د. محمد صبري السعدي، الواضح في شرح القانون المدني، دار الهذى، الجزائر، عام 2009، ص 236، نسخة 


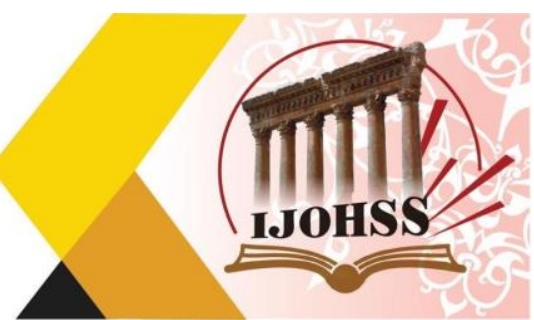

و هو ما أجازه قانون الإثبات المصري حيث نص على أنه \للهحكمة أن تستجوب من يكون حاضرًا من الخصوم الإبه

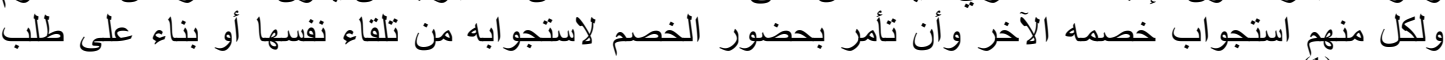

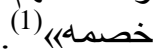

ثالثاً : التعريف القضائي للإقرار

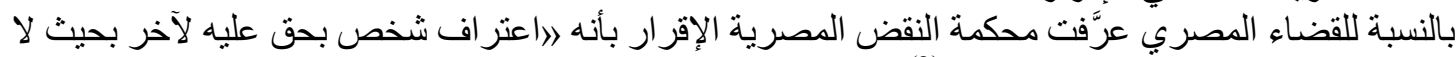

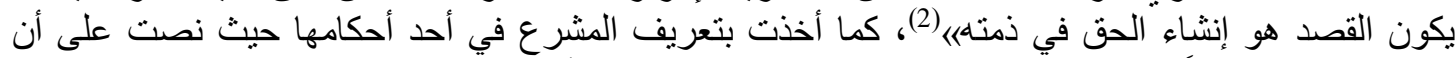

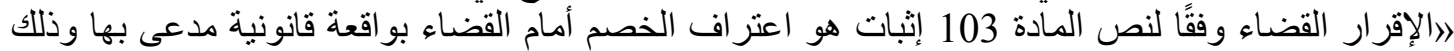

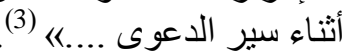

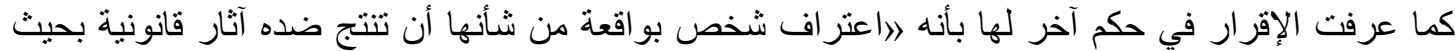

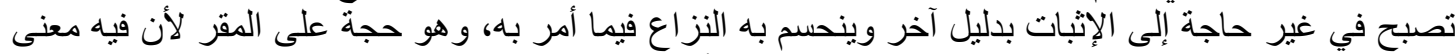

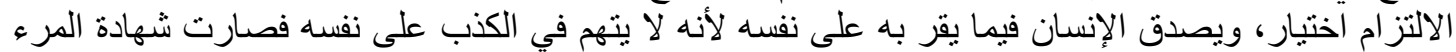

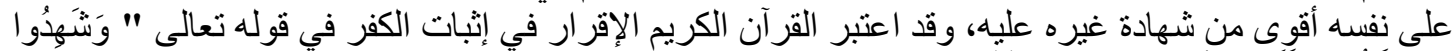

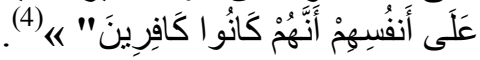

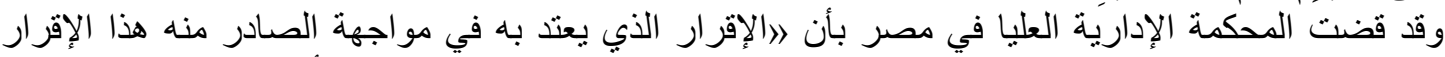

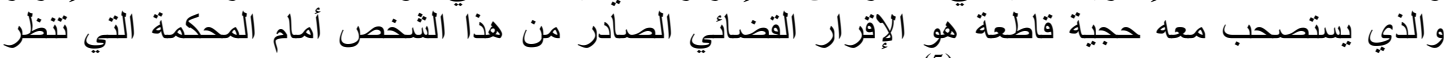

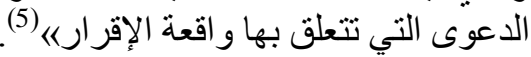

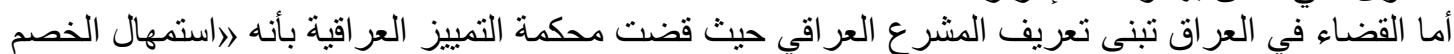

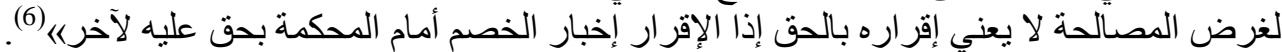

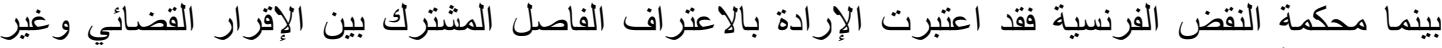

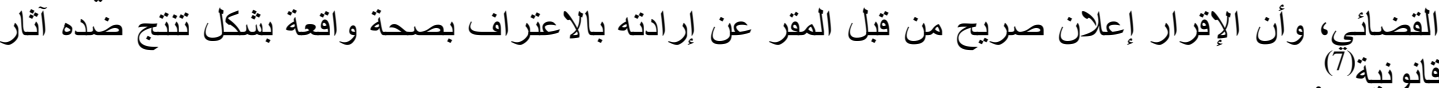
وبالتالي فان الإقرار القضائي هو الاعتراف الذى بصدر من الخصم أمام القاضي في واقعة معينة اثناء سبر

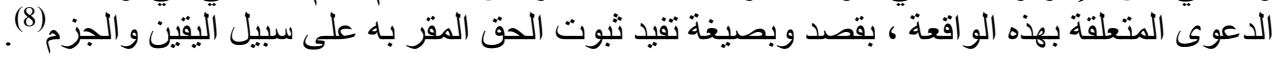

الد محمد شكري سرور، موجز أصول الإثبات، دار الفكري العربي، بدون سنة نشر، ص 162، وكذلك انظر د.pdf

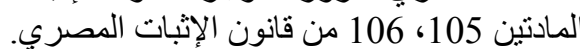

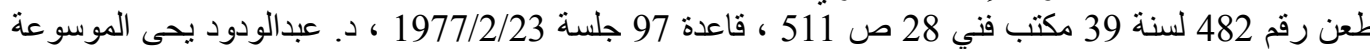

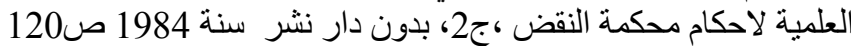

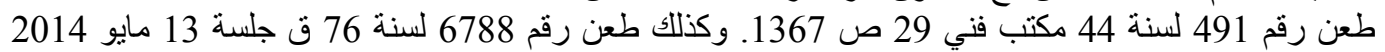

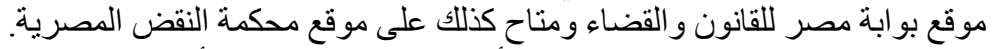
الطعنان رقمي 475، 478 لسنة 65 ق أحوال شخصية جلسة 5 أغسطس المصرية.

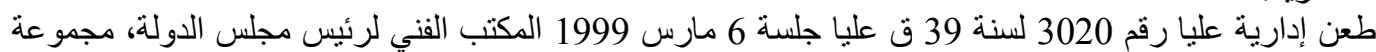
المبادئ القانونية التي قررتها المحكمة الإدارية العليا السنة 463 من أول أكتوبر سنة 1998 إلى إلى آخر سبتمبر سنة

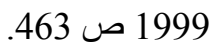
قرار رقم 1974/42/977 في 1975/4/6 منشور في مجموعة الأستاذ إبراهيم المشاهدي، المبادئ القانونية في

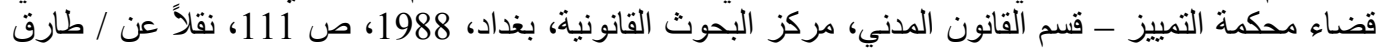

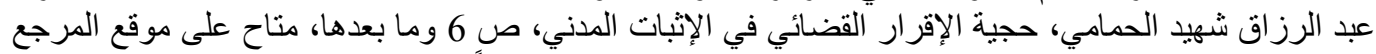

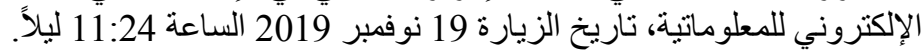

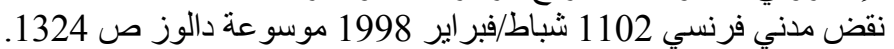
طعن 195 لسنة 50 ق جلسة 22 ديسمبر 1983 موقع محكمة النقض المصرية. 
1- بيتضمن الإقرار اعتر اف المقر بثنبوت حق على نفسه بينما؛ الثهادة هي إخبار الثناهد بثبوت حق لغيره على

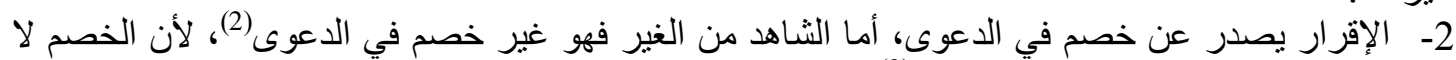

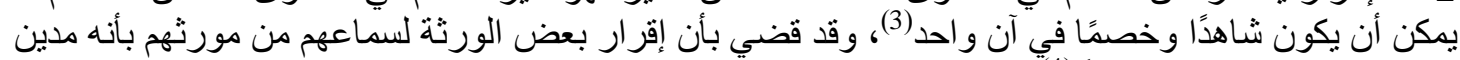

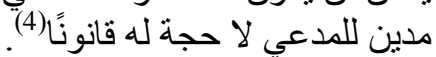

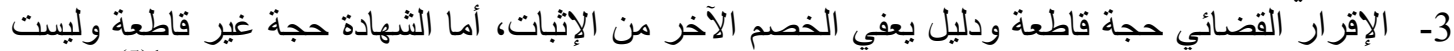

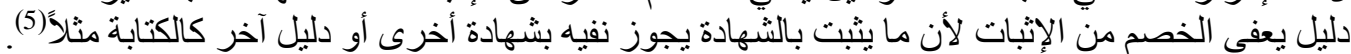

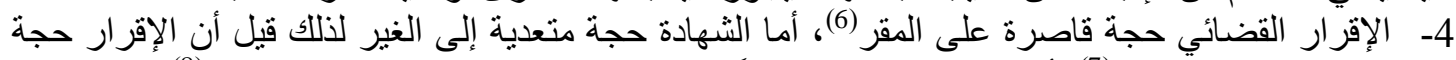

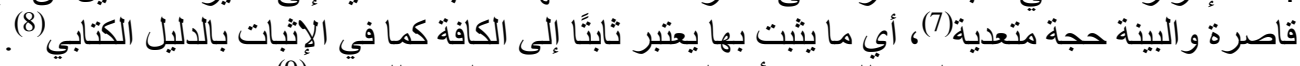

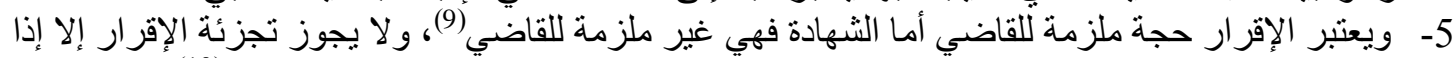

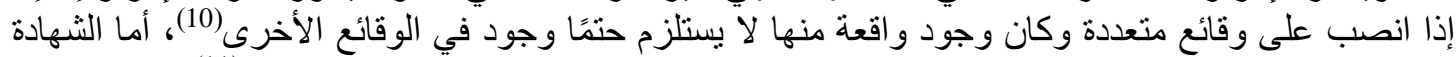

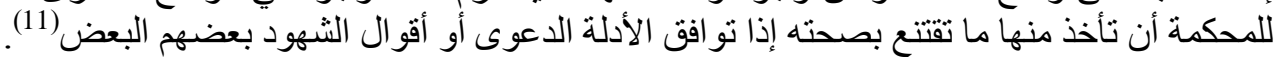

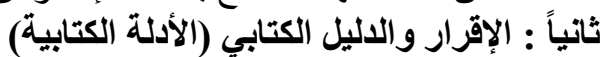

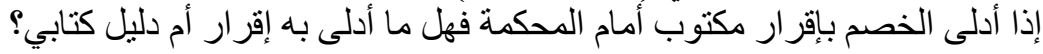

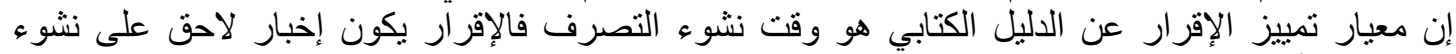

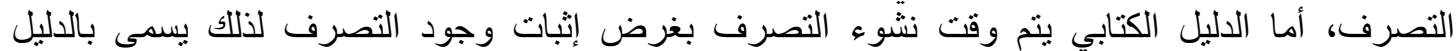

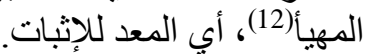

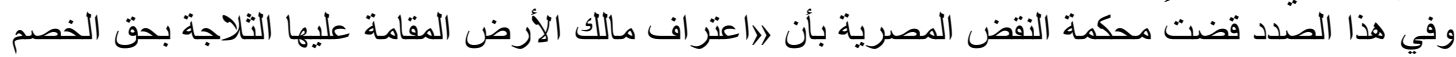

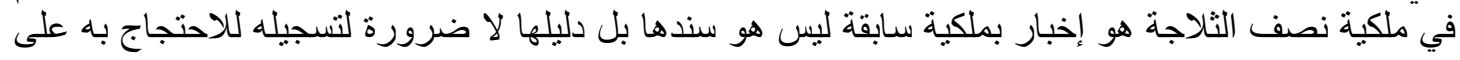

(1) د. لاثثين محمد يونس الغاياتي، دور الثهادة في الإثبات، بحث منشور في مجلة كلية الثريعة و القانون، طنطا، العدد

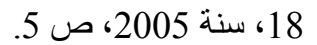

د. عصمت عبد المجيد بكر ، طرق الإثبات، المرجع السابق، ص 2005 صن 219. المادة 83 من قانون الإثبات العراقي.

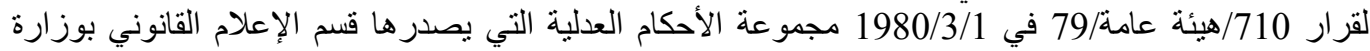

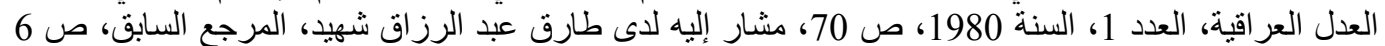

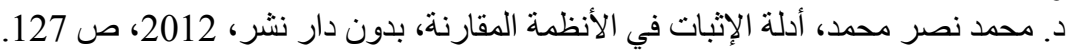

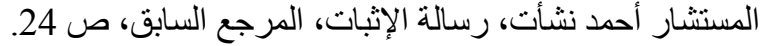

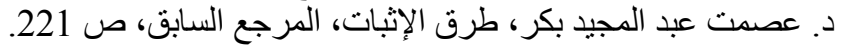

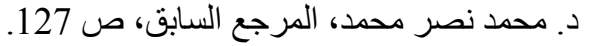

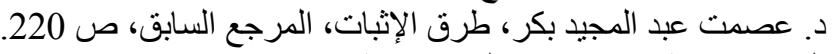

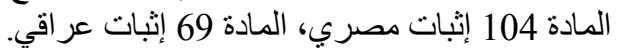

$$
\begin{aligned}
& \text { الدادة } 85 \text { إثبات عر اقئي. }
\end{aligned}
$$

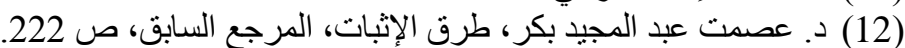

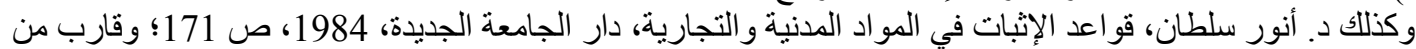

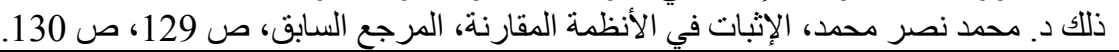




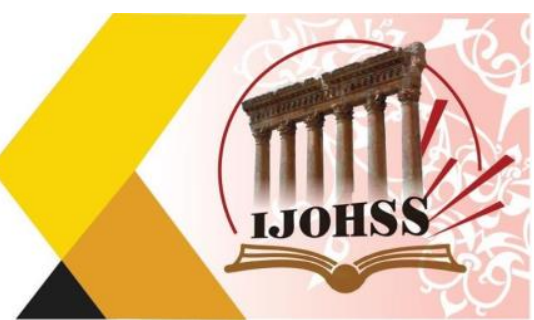

المقر (1) ، وقضت محكمة التمييز العر اقية بأنه 》الا تعتبر العريضة الموقعة من قبل الخصم إقرارًا وإنما تعد دليلاً كتابيًا (2)

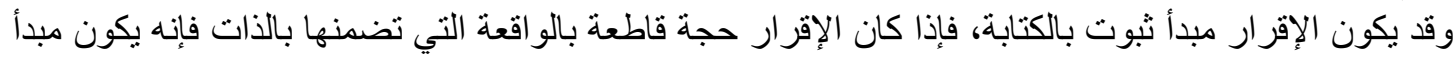

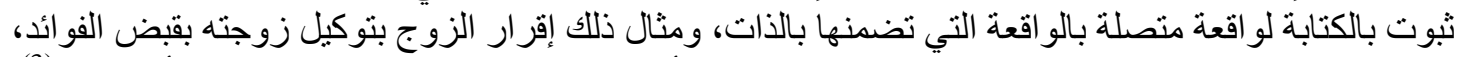

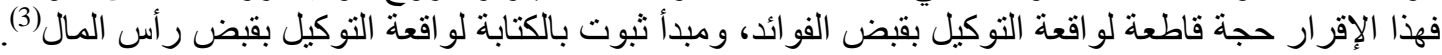

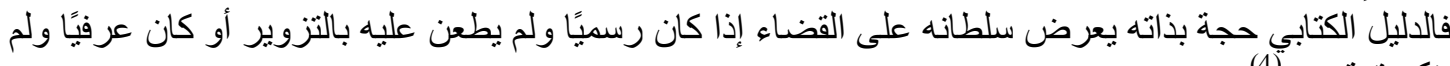

\section{المطاب الثاني \\ أركان الإقرار القضّائي}

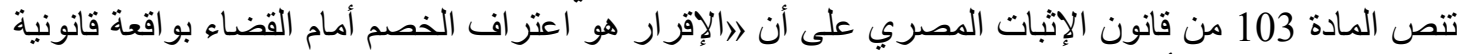

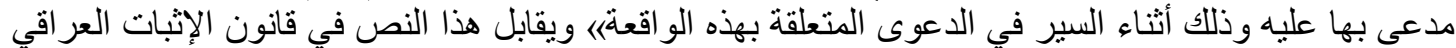

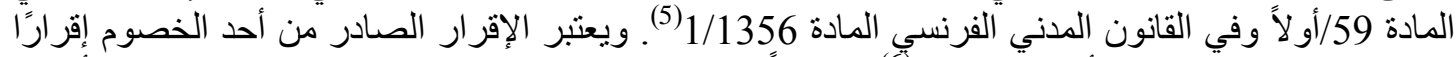

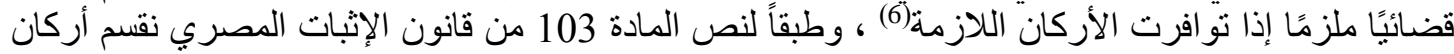

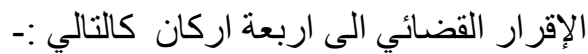

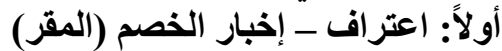

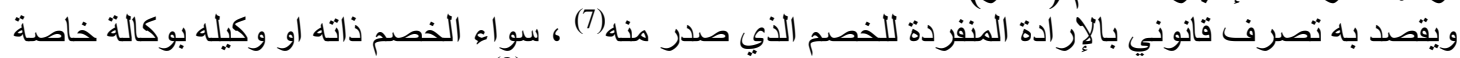

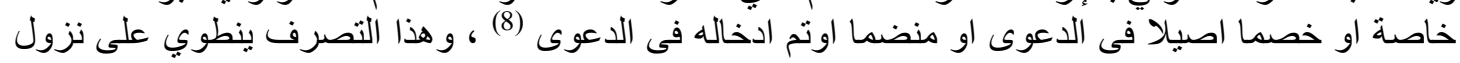

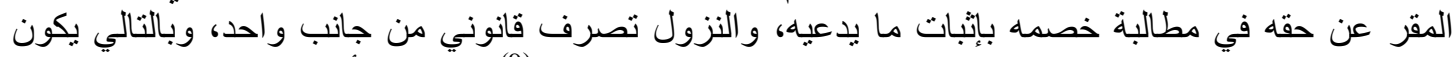

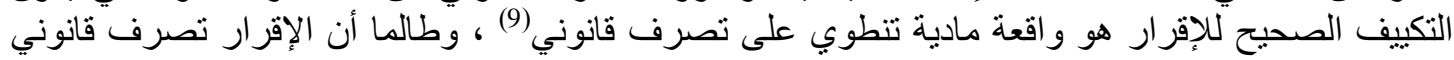

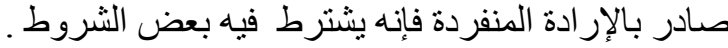

شروط الاقرار

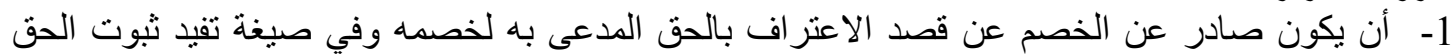

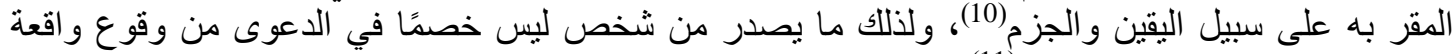

(1) نقض 267 لسنة 36 ق جلسة 20 يناير 1972 مكتب فني العدد 1 س 23 ص 76 موقع بوابة مصر للقانون و القضاء. قرار رقم 1973/31/1107 في 1973/12/27 لدى طارق عبد الرزاق شهيد، المرجع السابق، ص صاقد 14 وما بعدها.

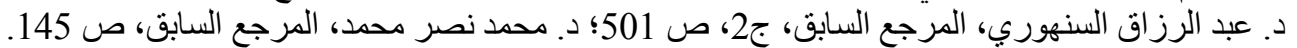

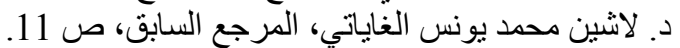

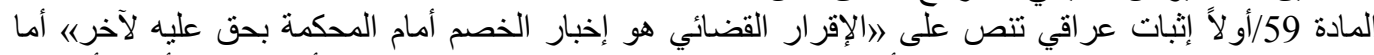

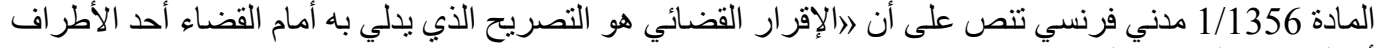
أو المفوض الخاص بالتوقيع عنهاه.

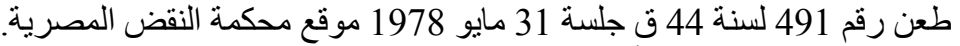

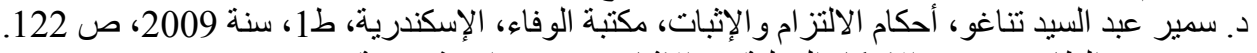

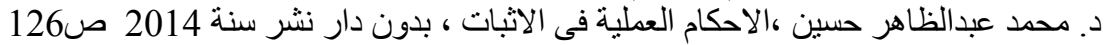

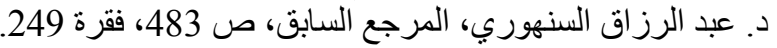

(10) طعن 195 لسنة 50 ق جلسة 22 ديسمبر 1983، طعن رقم 8 لسنة 33 قل جلسة 30 قلئة 30 يونيو 1965 موقع محكمة

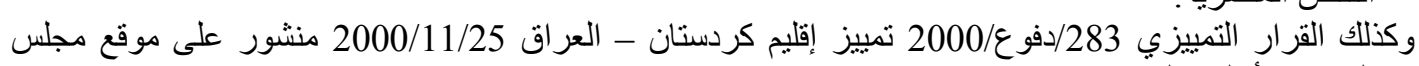

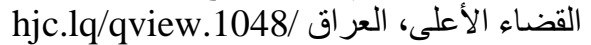

(11) د. عباس العبودي، شرح أحكام قانون الإثبات ـ در اسة مقارنة، مكتبة السنهوري، بيروت، 2017، ص 170. 


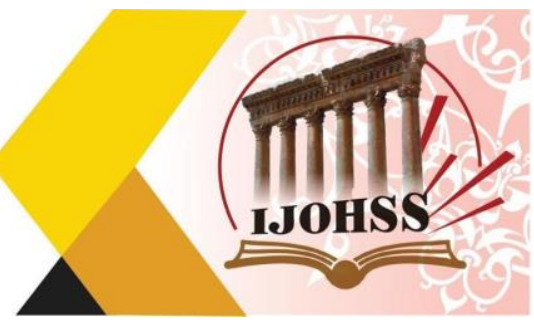

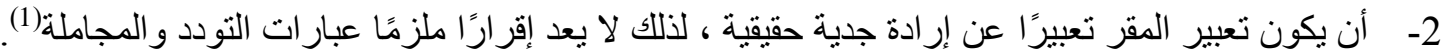

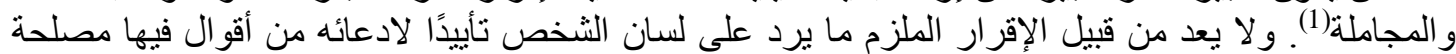

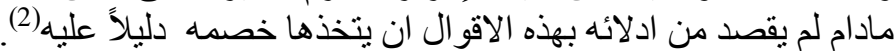

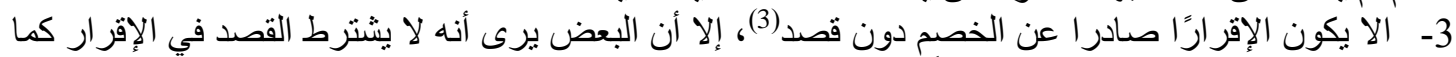

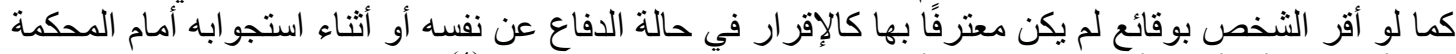

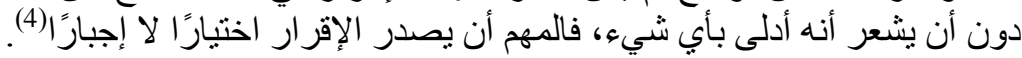

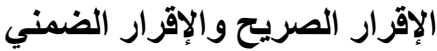

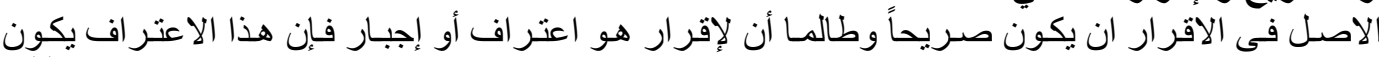

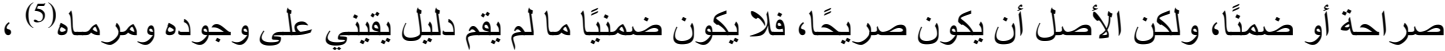

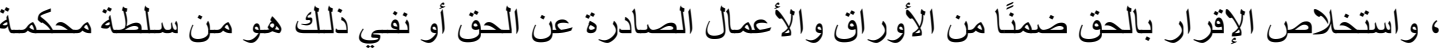

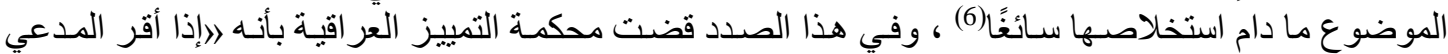

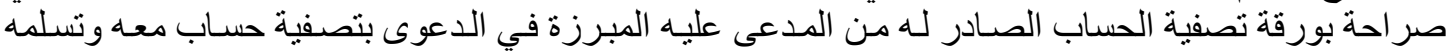

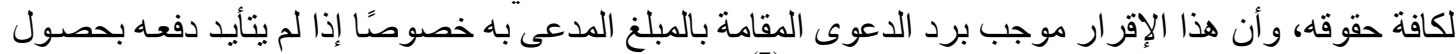

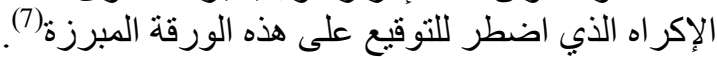

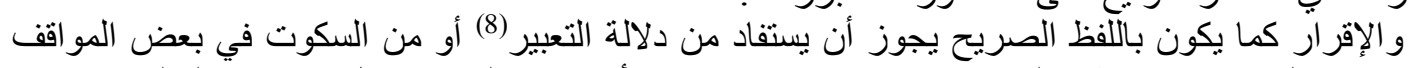

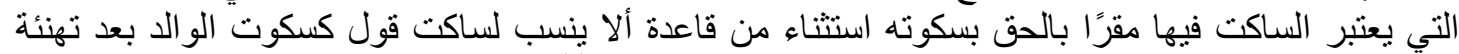

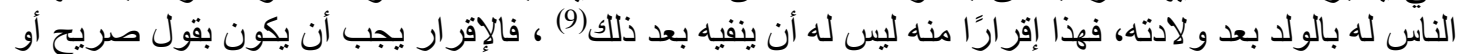

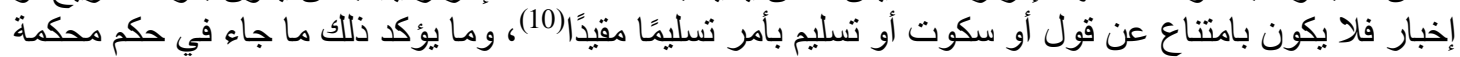

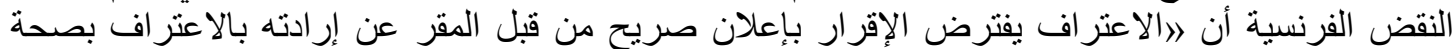

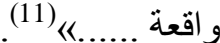
ولكن يندر أن يكون الإقرار ضمنيًًا(12)، لأنه يشترط فيه أن يكون بصيغة تفيد ثبوت الحق المقر به على سبى سبيل

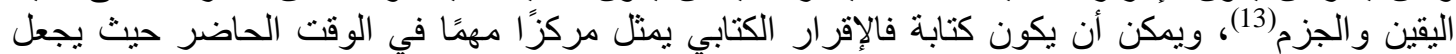

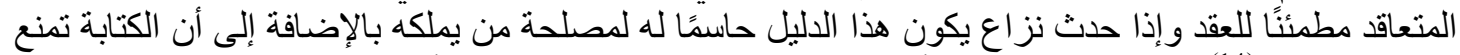

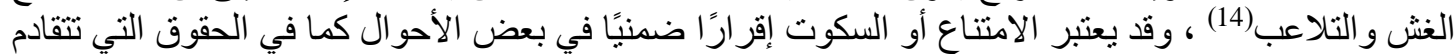

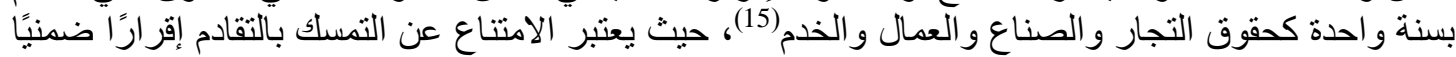

طعن رقم 1062 لسنة 47 ق جلسة 1978/4/5، مكتب فني 29 ص الام 949 ، قاعدة 187 د. عبدالودود يحى ،

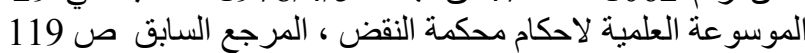

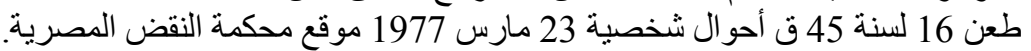

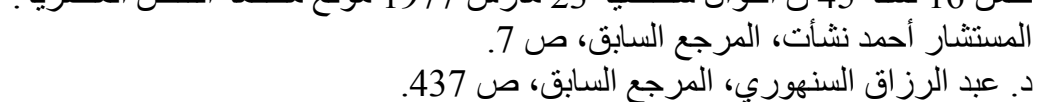

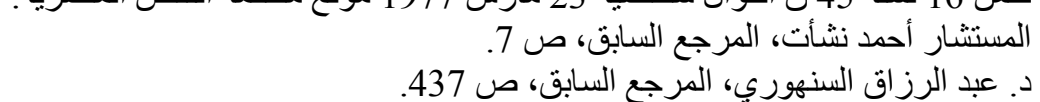

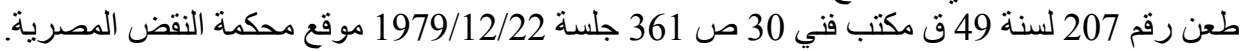
طعن رقم 488 لسنة 48 جلسة 3 يونيو 48 في في 1982 موقع محكمة النقض المصرية. قرار رقم 42 ........ أولى/1989 في 1989/4/30 أثنار إليه د. عصدت عبد الفيد الميد بكر، طرق الإثبات، المرجع

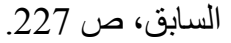
8 طعون 481/478/475 لسنة 65 ق جلسة 5 أغسطس 1927 أسل 1996 أحوال شخصية موقع محكمة النقض المصرية. طعن رقم 17 لسنة 46 ق جلسة 22 فبر اير 1978 أحو ال شخصية موقع محكمة النقض المصرية.

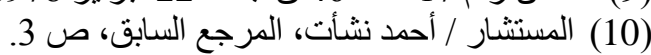

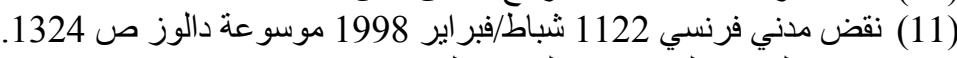

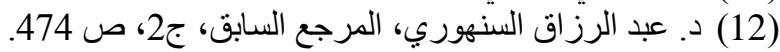

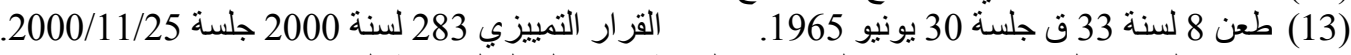

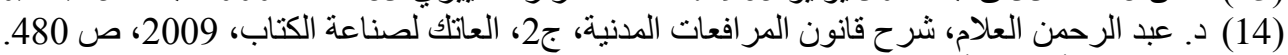
. 


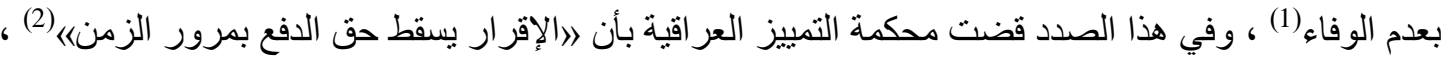

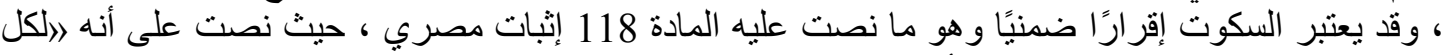

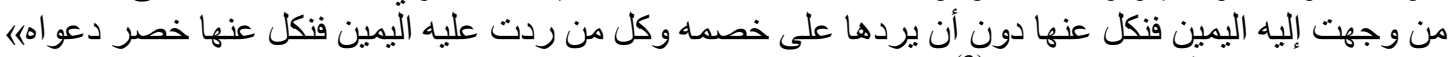

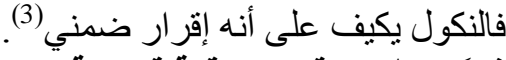

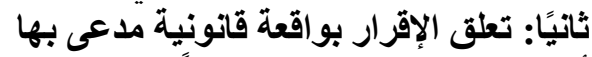

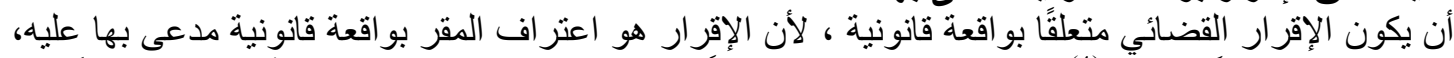

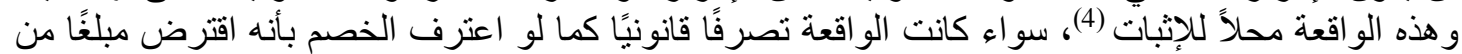

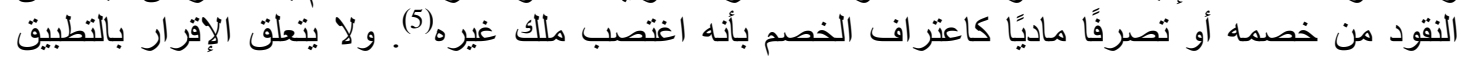

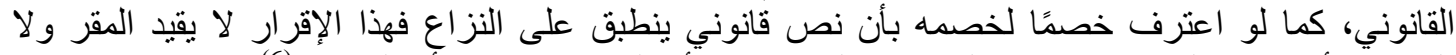

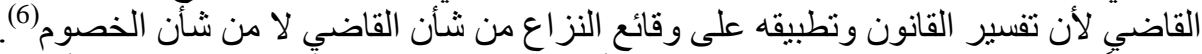

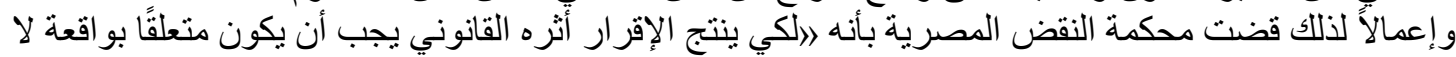

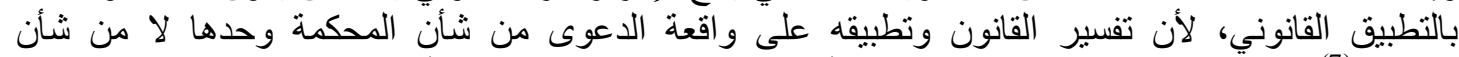

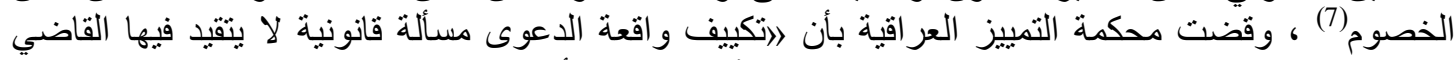

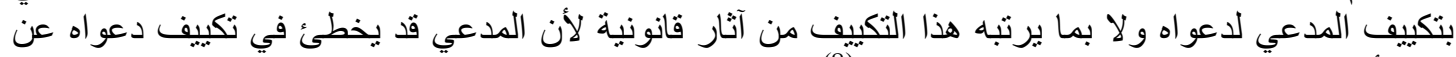

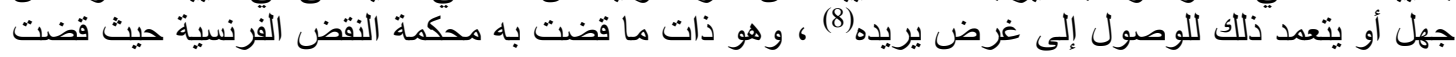

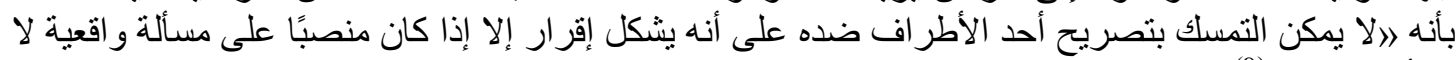

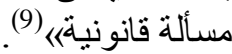

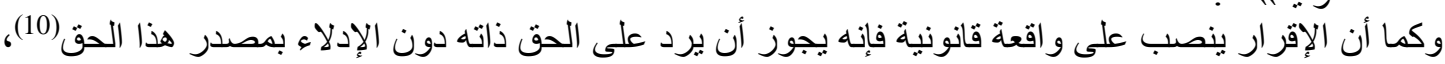

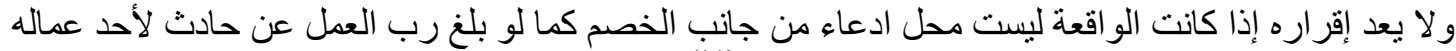

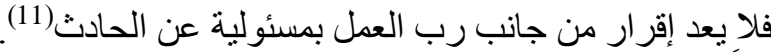

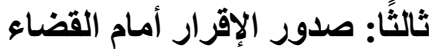

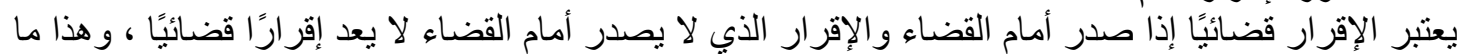

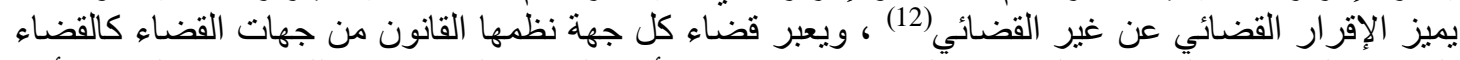

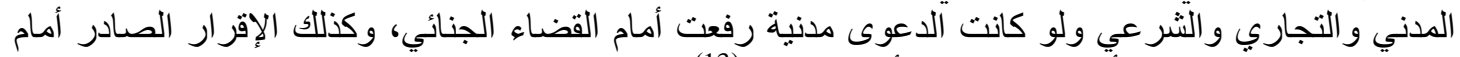

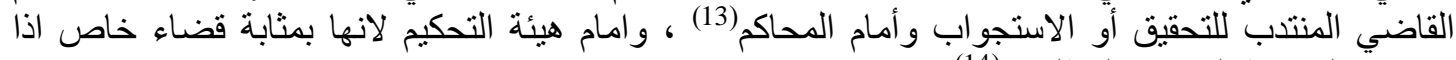

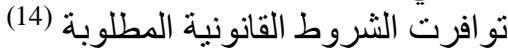

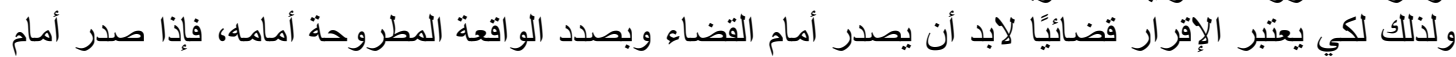

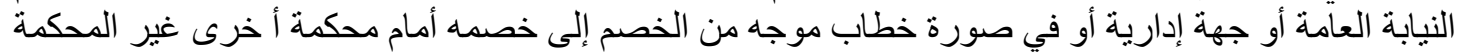

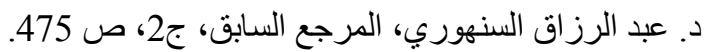

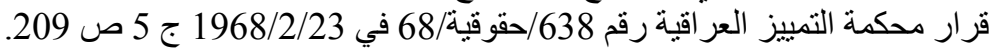

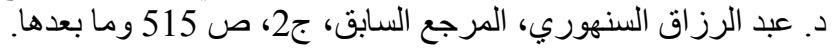

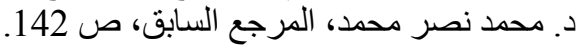

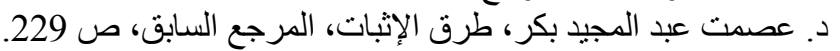

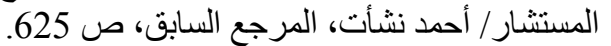

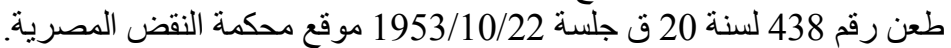

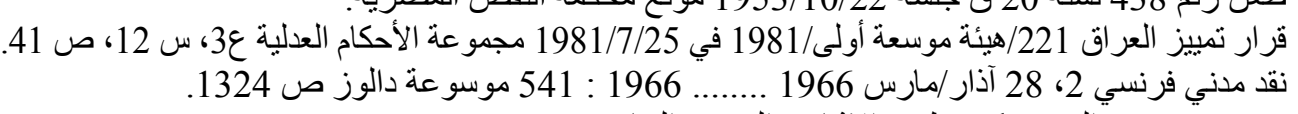

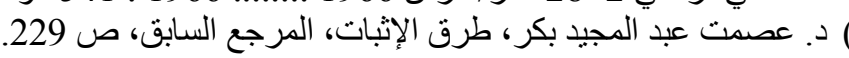

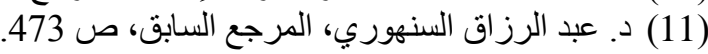

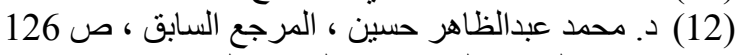

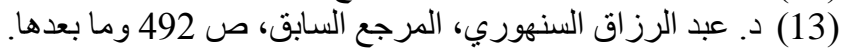

(14) د. محمد عبدالظاهر حسين ، المرجع السابق ، ص ص 126 


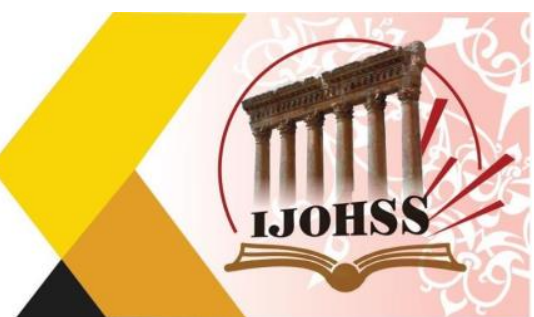

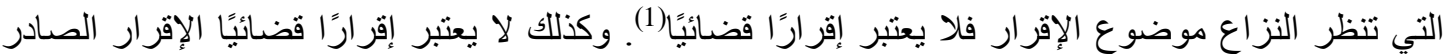

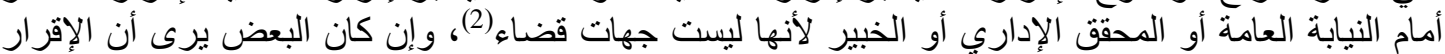

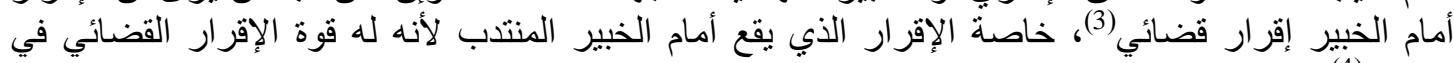

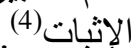

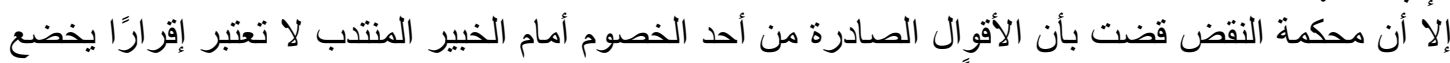

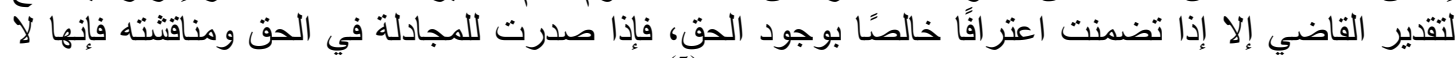

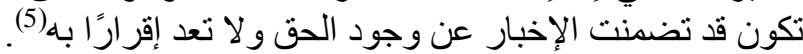

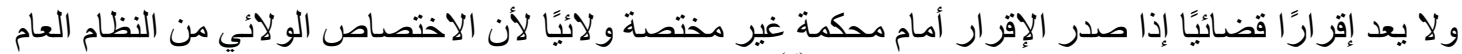

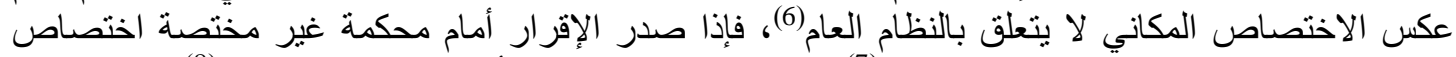

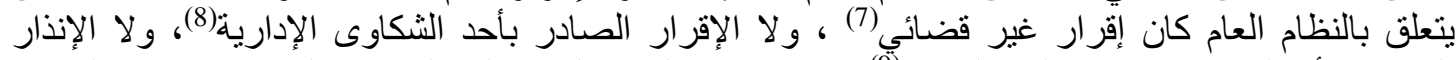

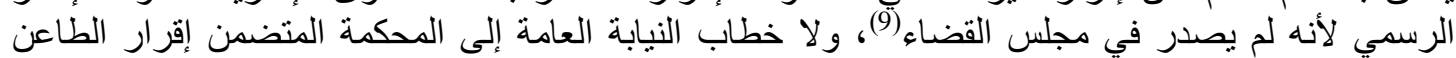

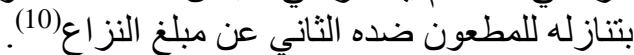

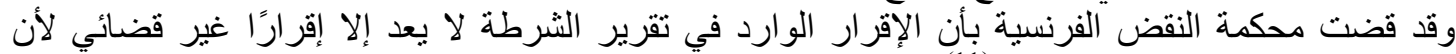

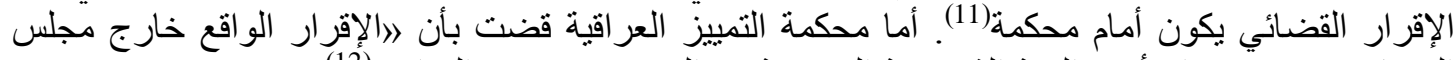

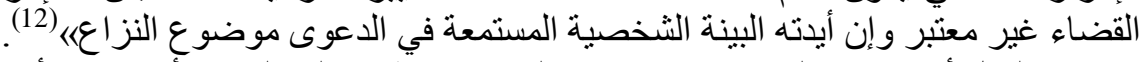

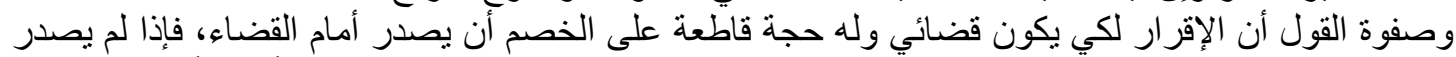

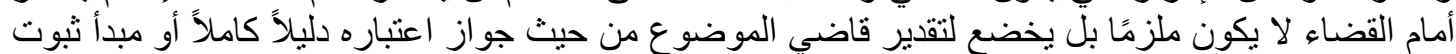

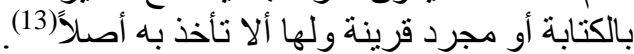

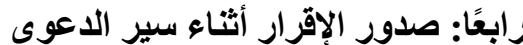

نص قانون الإثبات المصري وكثير من قوانين الدول العربية على صدور الإقرار أثناء سير الدعوى حتى يكون

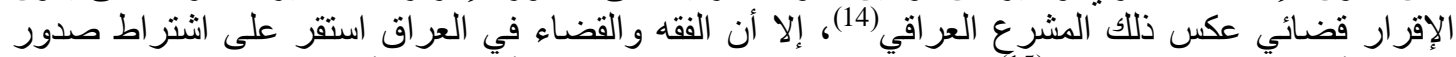

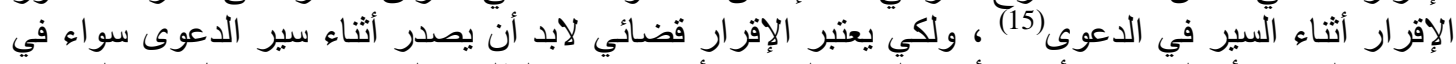

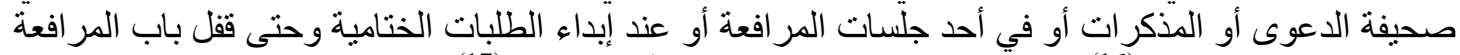

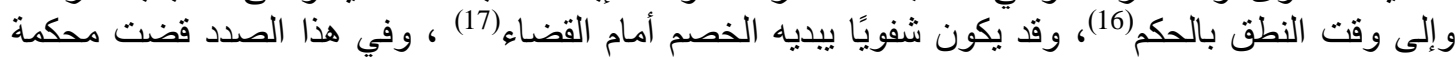

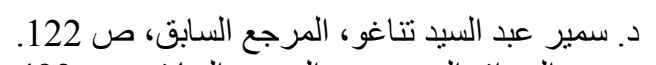

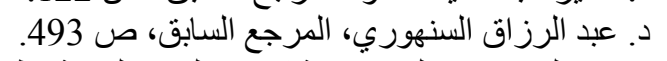

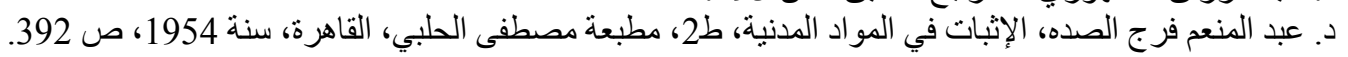

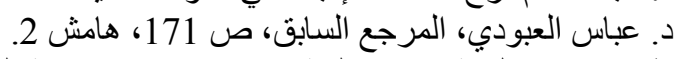

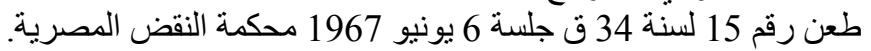

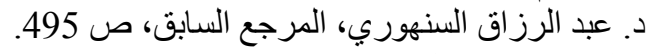

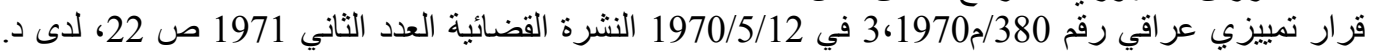

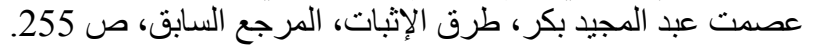

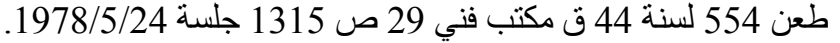

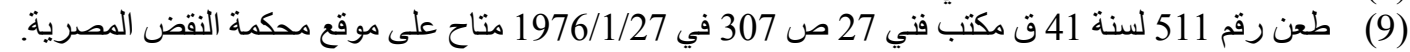

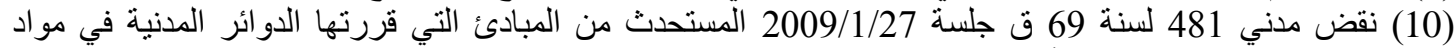

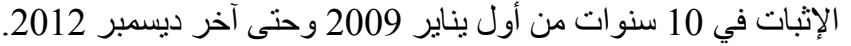

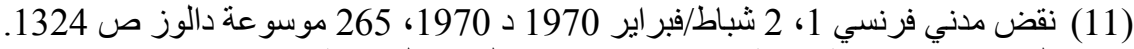

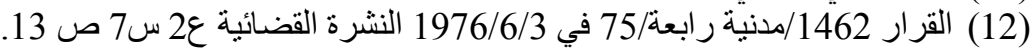

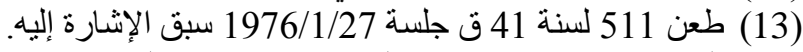

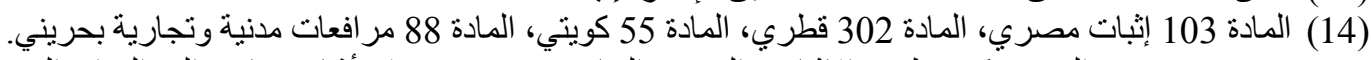

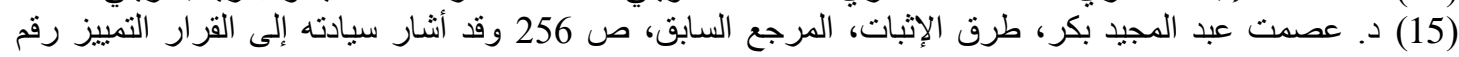




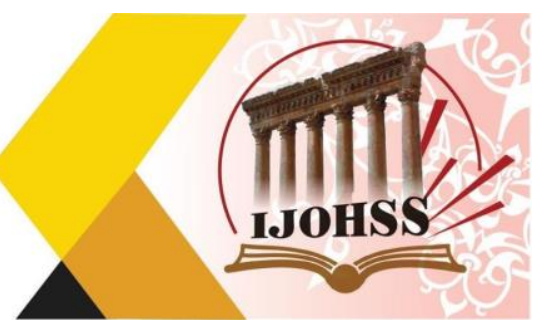

النقض المصرية بأنه اوقد برد الإقرار القضائى في صحيفة الدعوى التي يرفعها المقر أو في مذكرة يقدمها

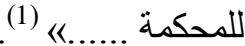
وثمة سؤال يطرح نفسه على بساط البحث هو هل الإقرار الصادر من المقر في دعوى أخرى يعتبر إقرارًا قضائيًا

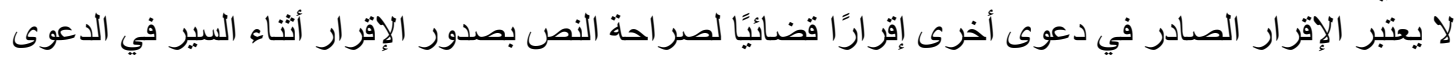

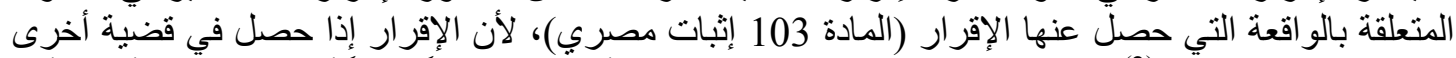

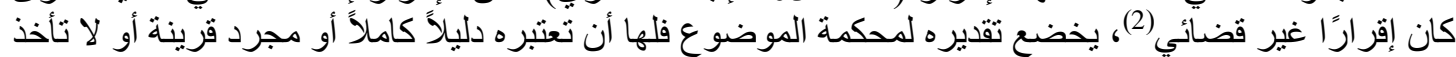

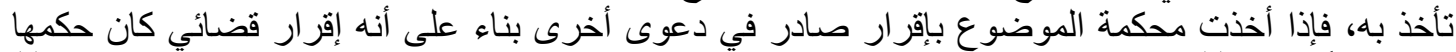

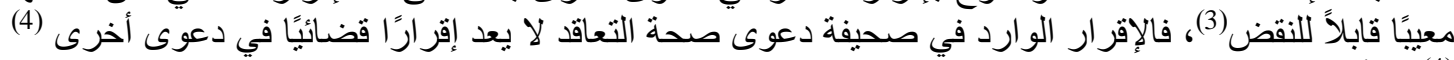

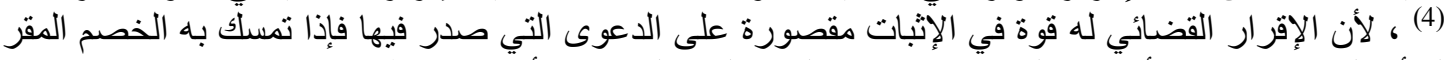

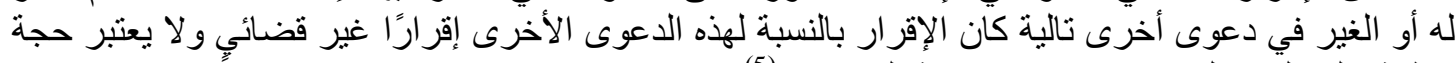

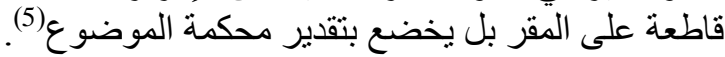

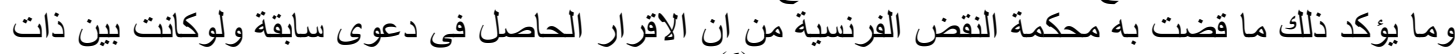

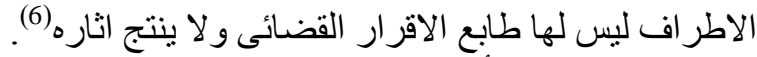

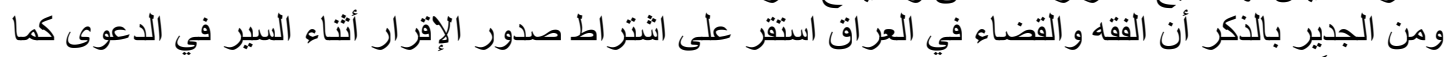

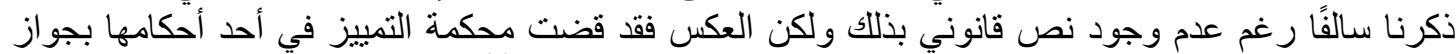

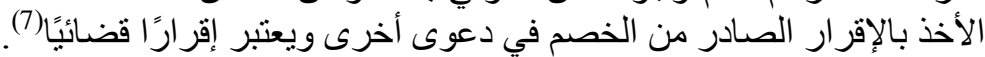

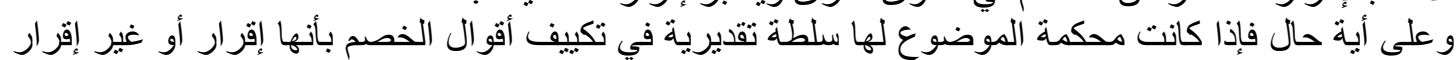

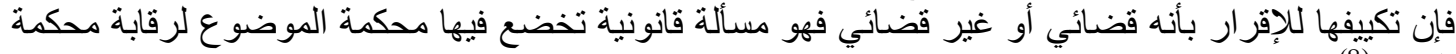
التمبيز (8)

وثمة سؤال آخر ما مصير الإقرار إذا حكم بعدم قبول الدعوى أو إبطالها؟.

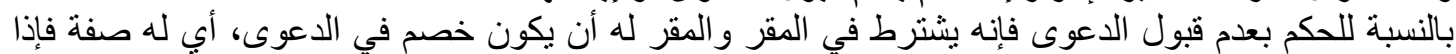

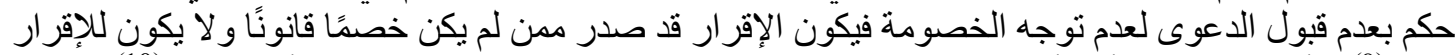

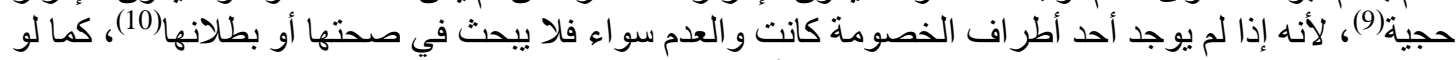

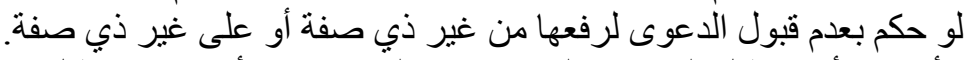

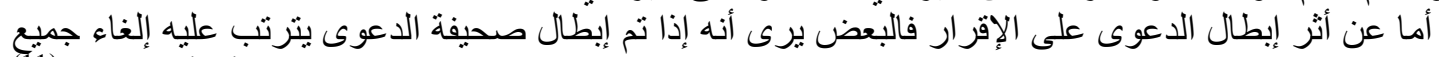

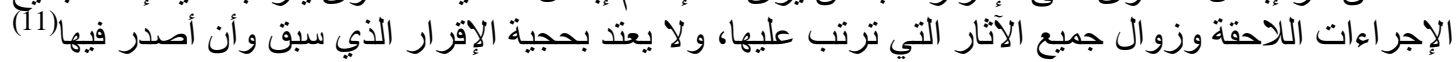

الطعنان رقما 2300، 3550 لسنة 65 ق جلسة 16 مايو 2006 مكتب فني مدني س 26، ص 460 موقع بوابة مصر للقانون و القضاء.

د. عبد الرحمن العلام، شرح قانون المر افعات المدنية، ج2، العاتك لصناعة الكتاب، القاهرة، ط2، 2009، ص 503.

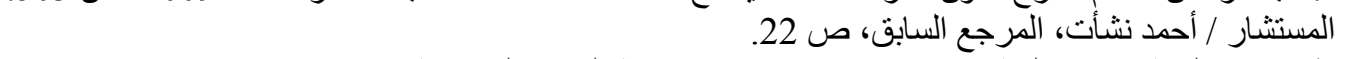

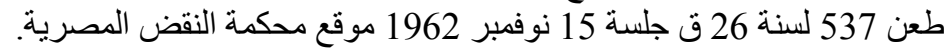

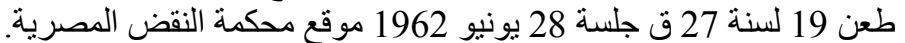

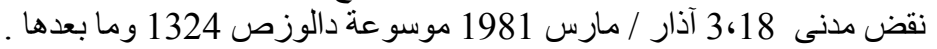

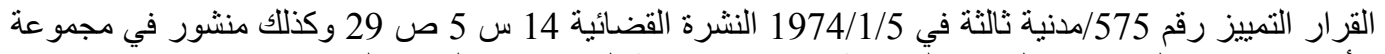

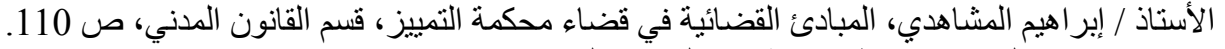

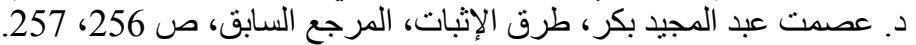

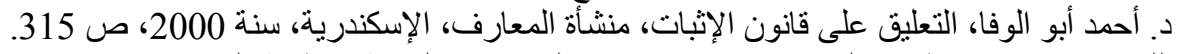

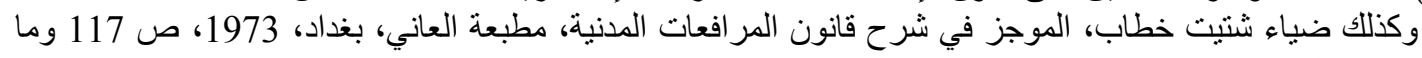




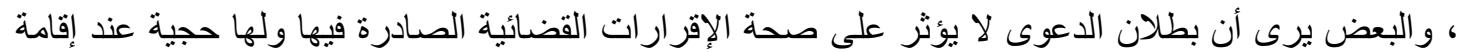

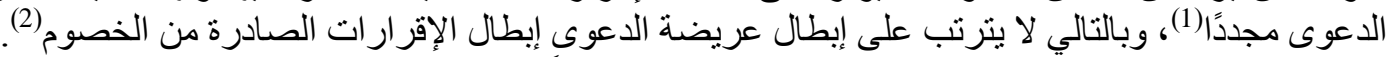

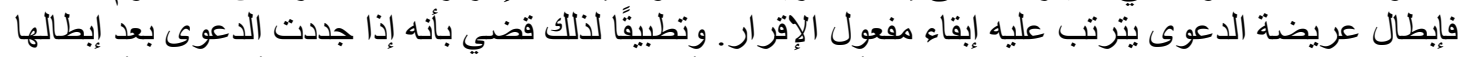

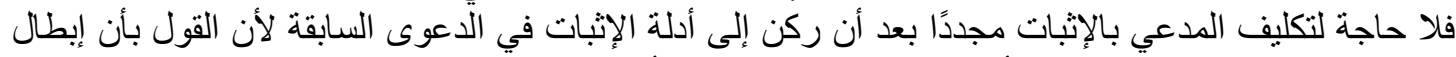

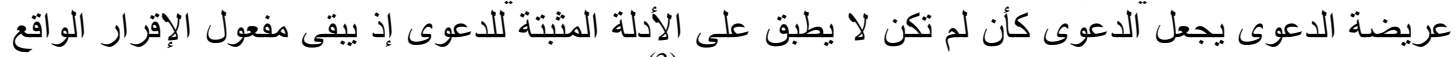

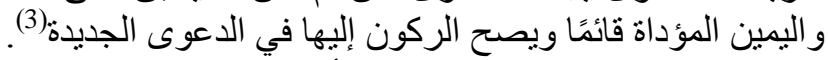

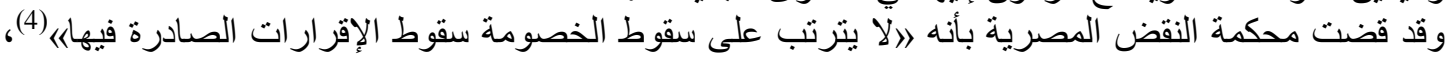

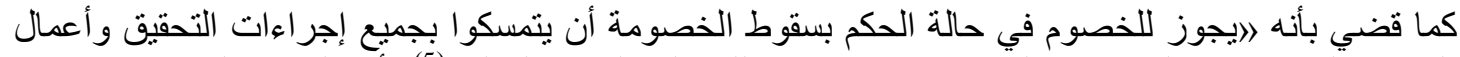

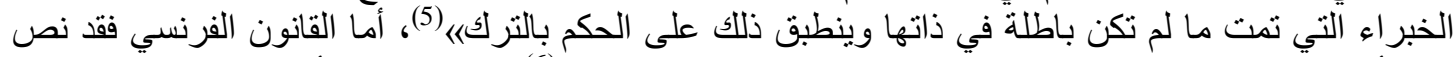

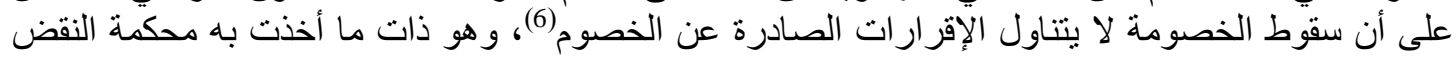

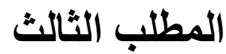 \\ شروط الإقرار القضائي}

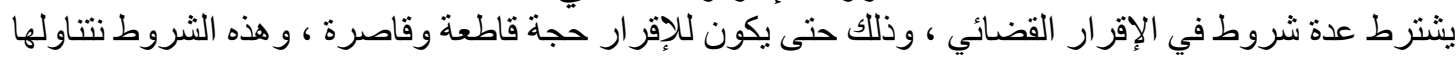

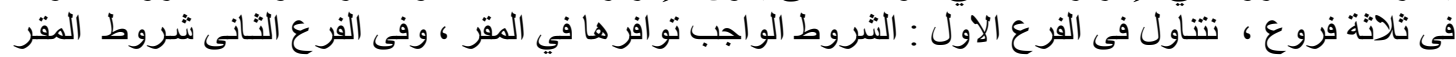

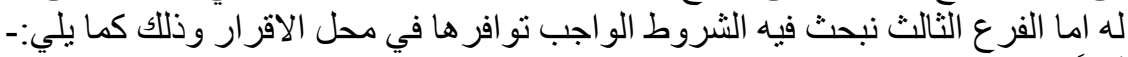

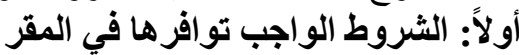

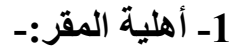

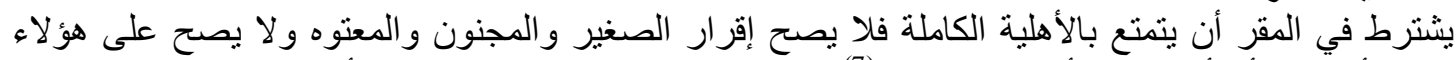

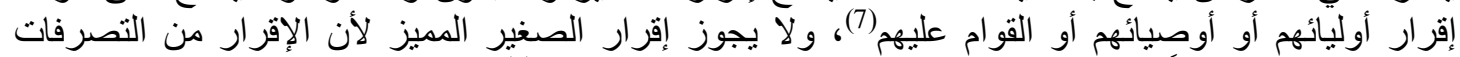

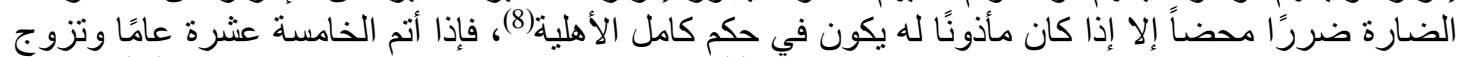

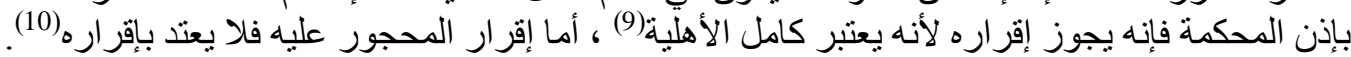

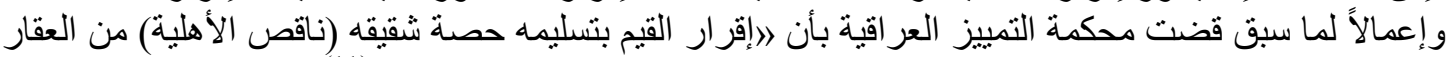

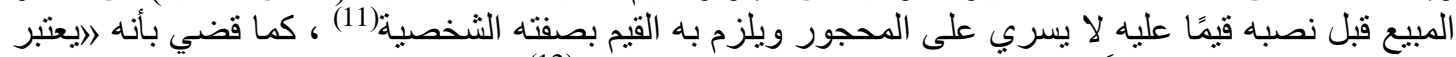

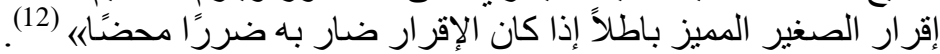

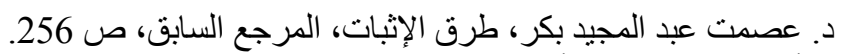

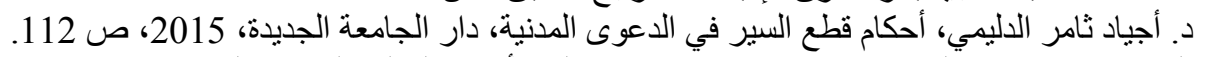

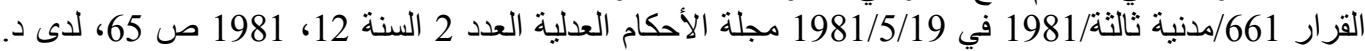

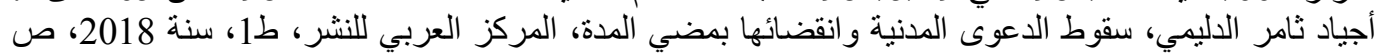
106 وما بعدها. طعن 199 لسنة 33 ق جلسة 1966/3/9 196/ موقع بداية مصر للقانون والقضاء وكذللك انظر المستشار / سعيد أحمد

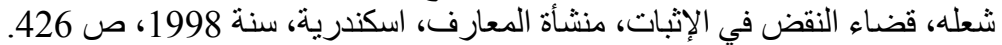

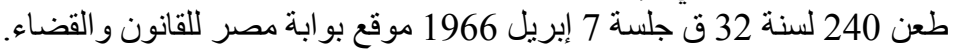

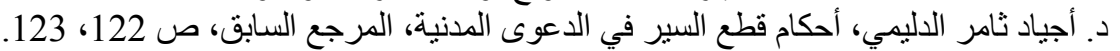

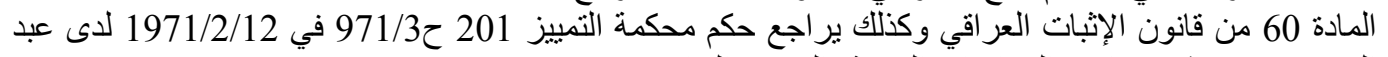

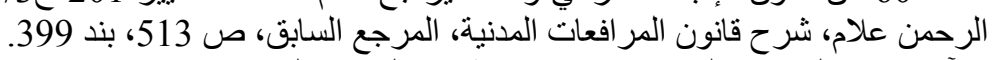

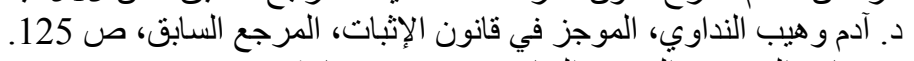

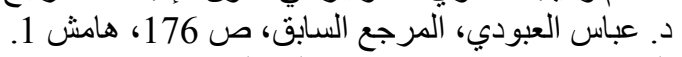

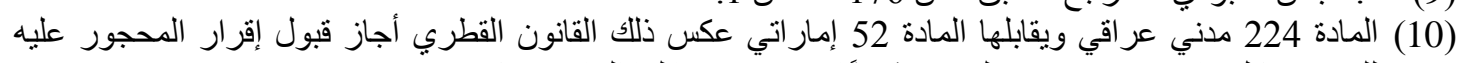

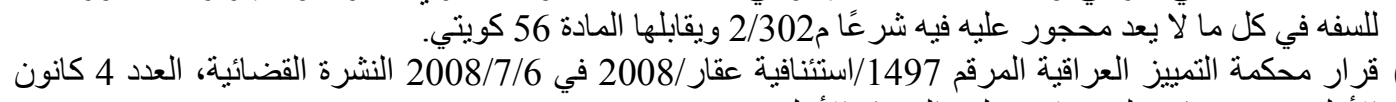
الأول 2008 متاح على موقع مجلس القضيز القياء الأعلى.

(12) تمييز عر اقى 1159/مدنية ثالثة/1974 في 1974/11/25 النشرة القضائية العدد 4 س 5 ص 18. 
العدد (14) أغططس 2020

Volume (14) August 2020

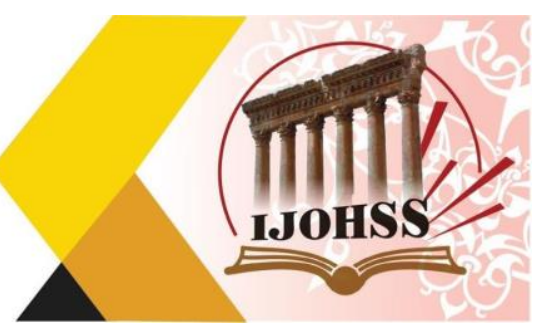

2- 2 سلامة الرضا من العيوب:-

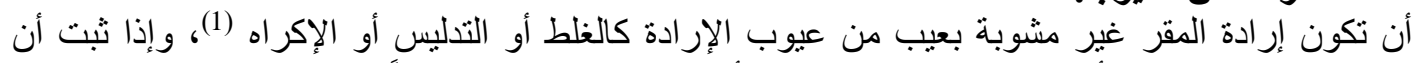

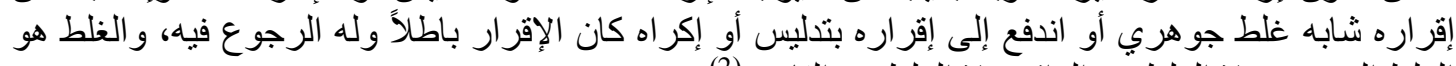

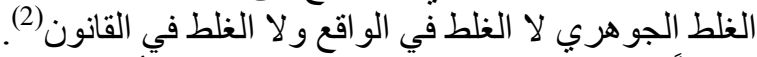

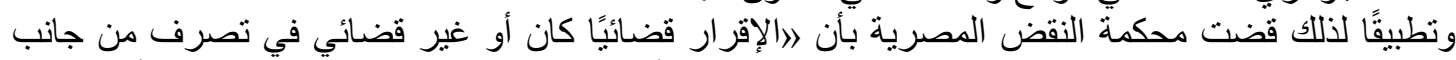

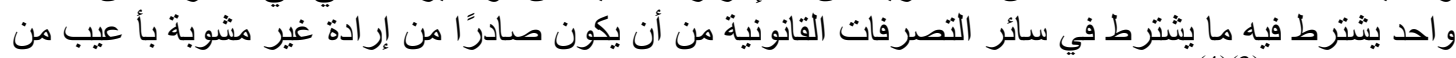

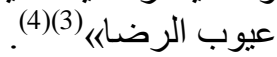
3- صدور الإقرار من المقر أو ممن له الدق في الإقرار عنه

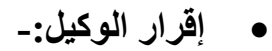

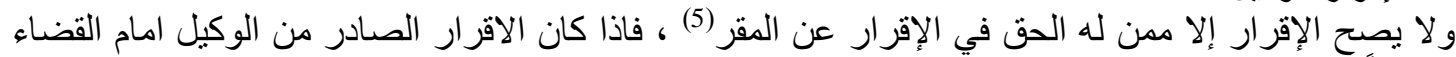

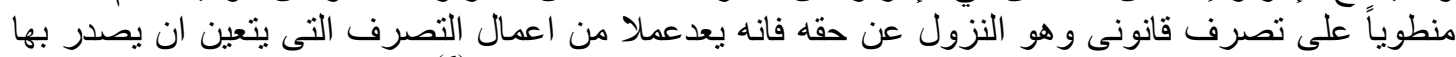

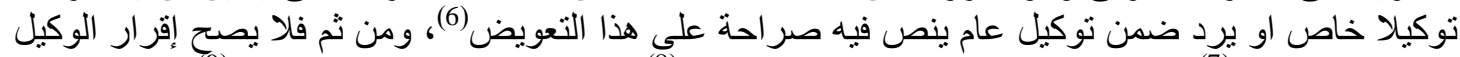

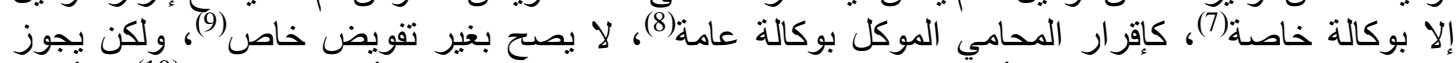

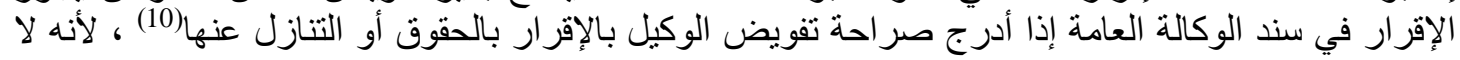

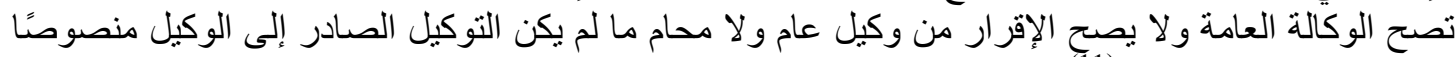

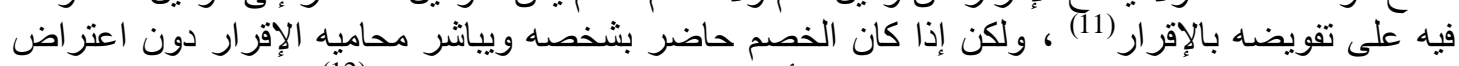

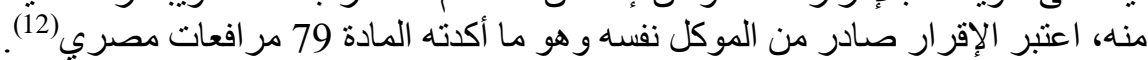

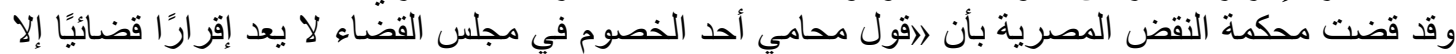

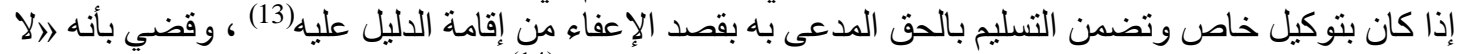

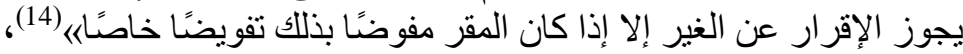

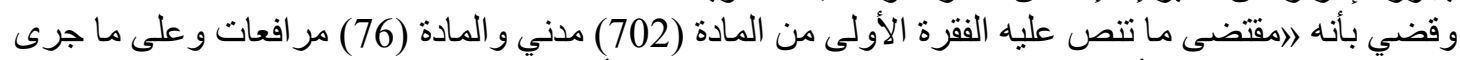

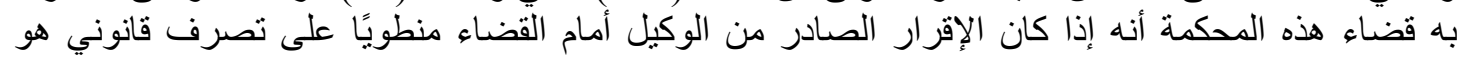

$$
\begin{aligned}
& \text { د. آدم و هيب النداوي، المرجع السابق، ص } 126 .
\end{aligned}
$$

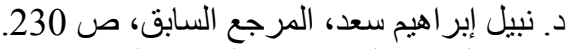

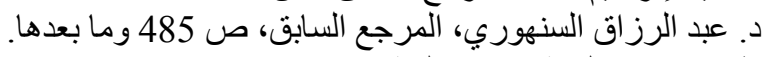

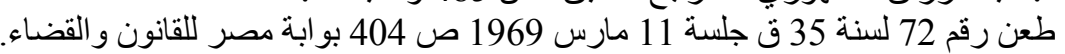

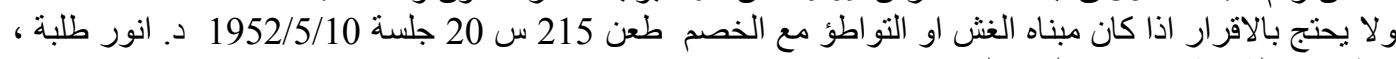

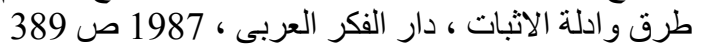

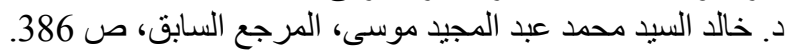

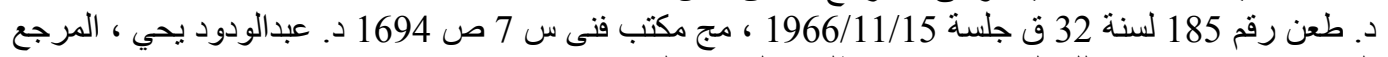

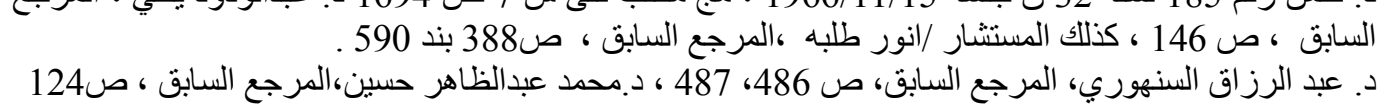

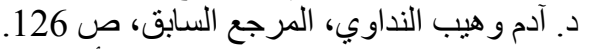

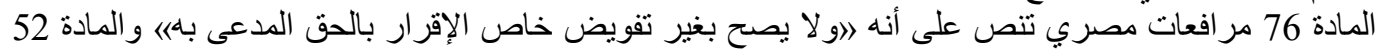

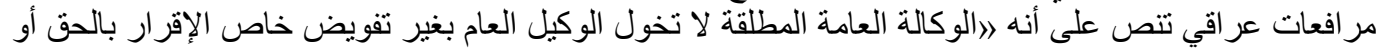

$$
\text { التنازل عنه ......... }
$$

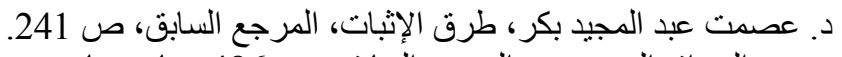

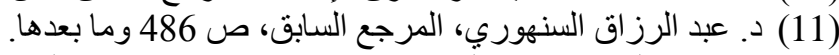

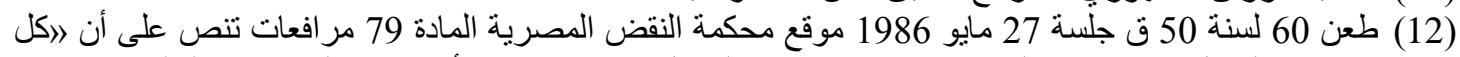

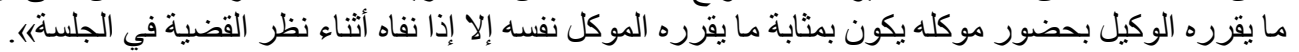

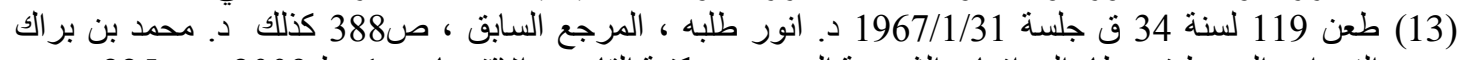

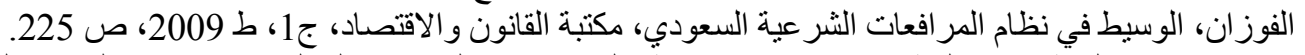

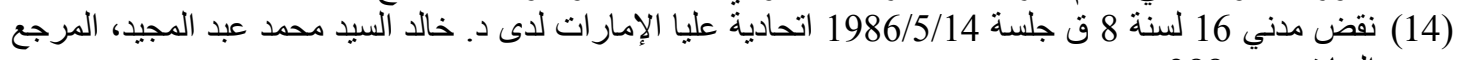


العدد (14) أغنطس 2020

Volume (14) August 2020

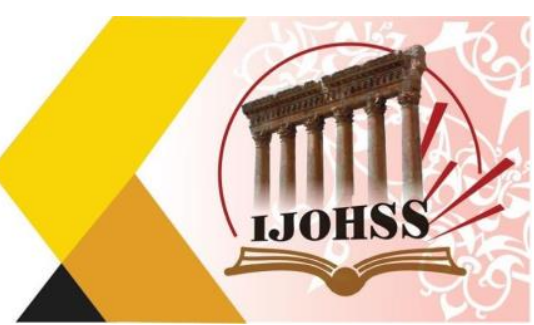

النزول عن حق فإنه يعد عملاً من أعمال التصرف التي يتعين أن يصدر بها توكيل خاص أو أن يرد ضمن توكيل

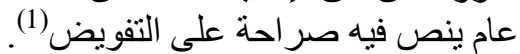

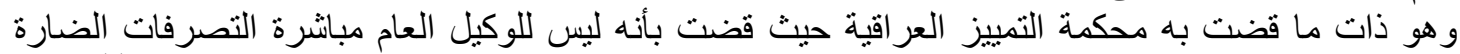

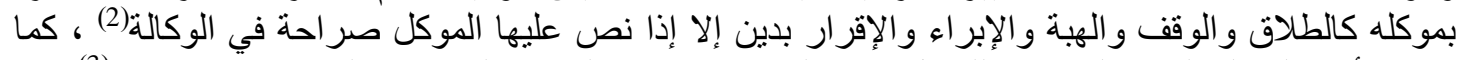

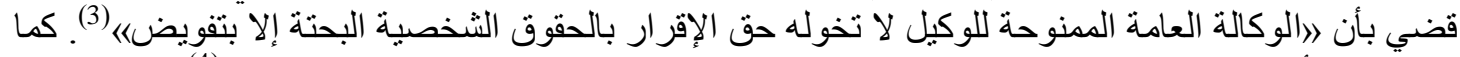

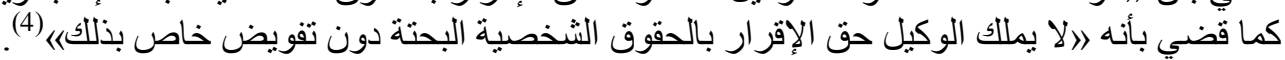

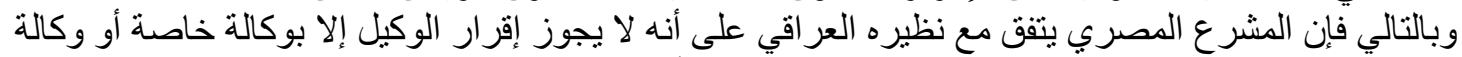

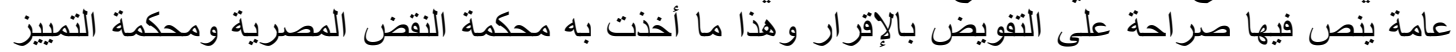

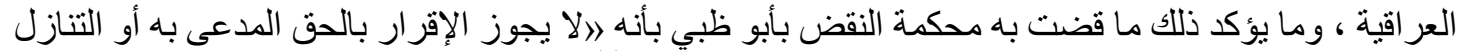

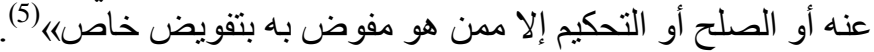

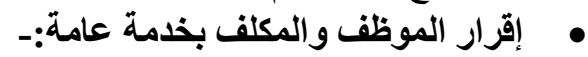

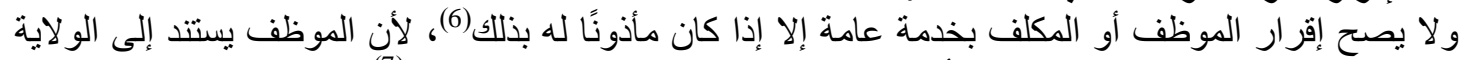

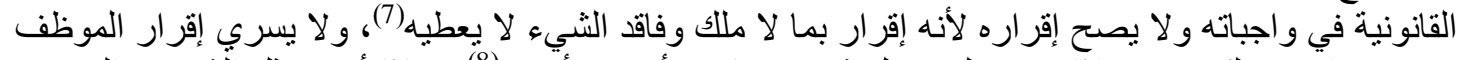

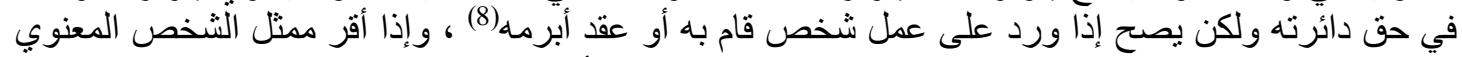

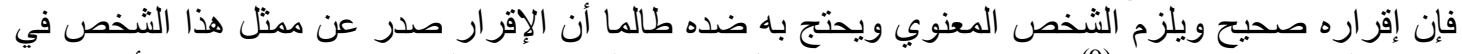

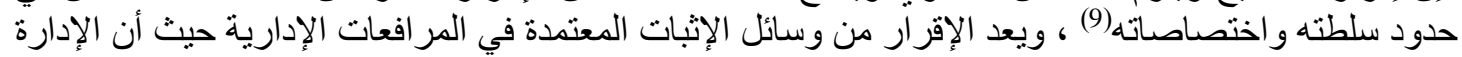

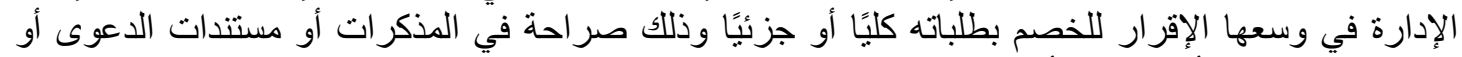

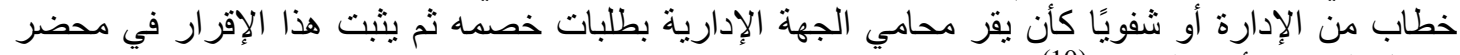

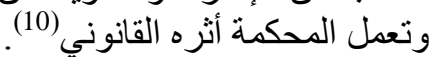

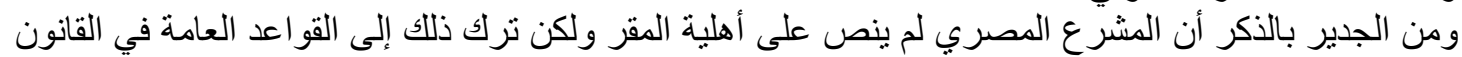

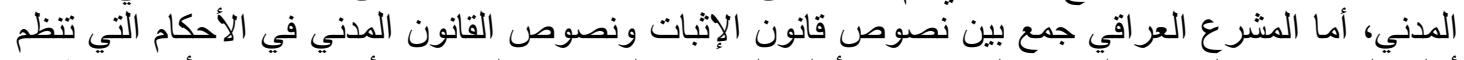

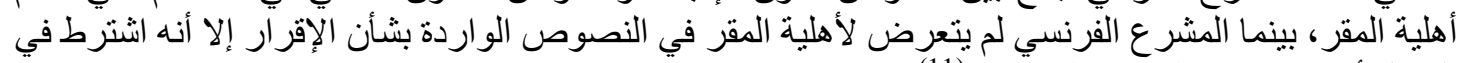

الوكيل أن يكون مفوضًا تفويضًا خاصنًا (11).

(1) طعن 74 لسنة 57 ق جلسة 1990/1/25، أ / محمود ربيع خاطر قانون المرافعات معلقًا عليه بأحدث أحكام محكمة

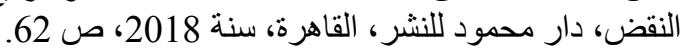

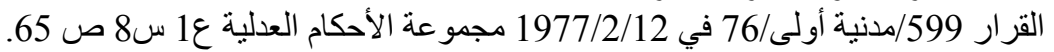

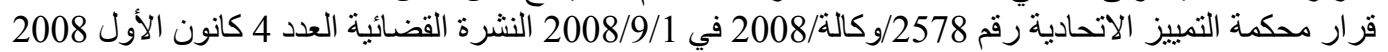

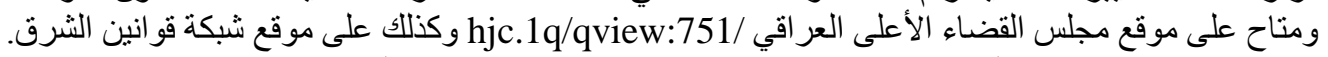

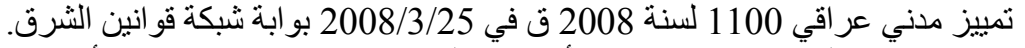

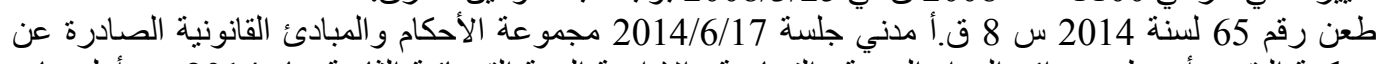

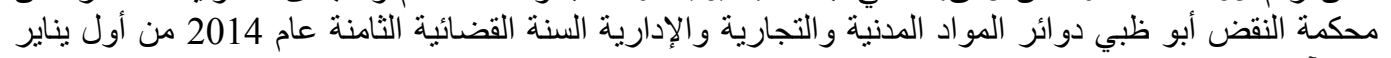

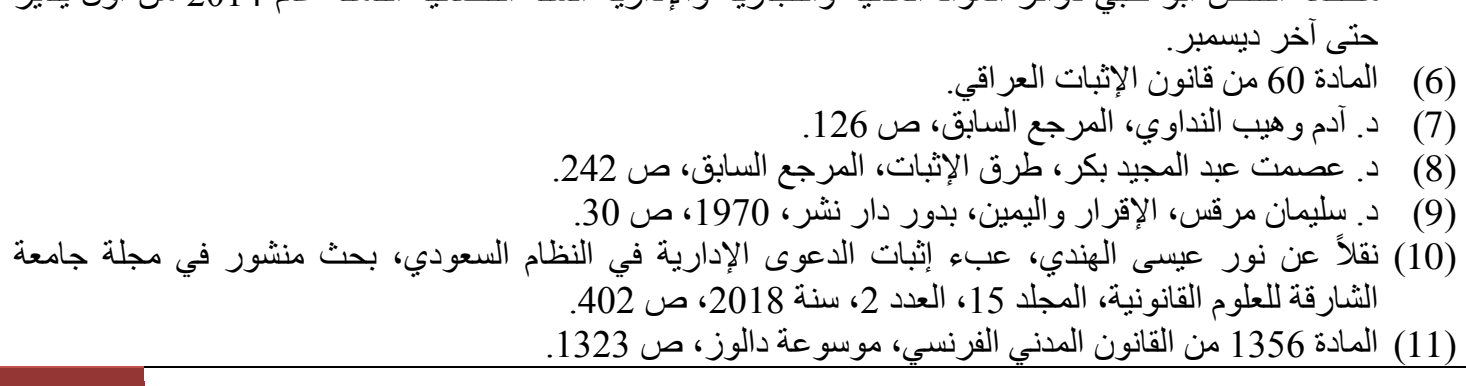

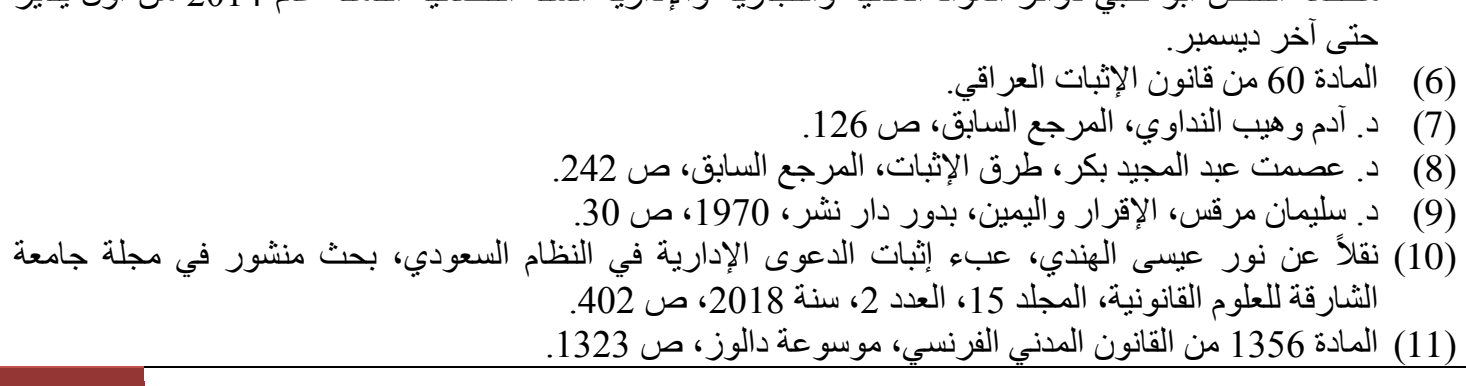

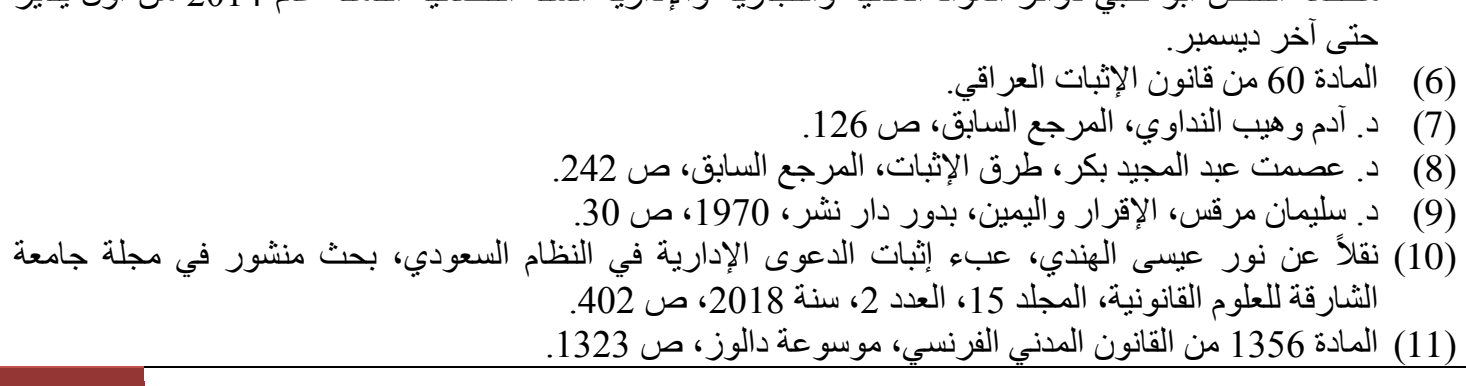

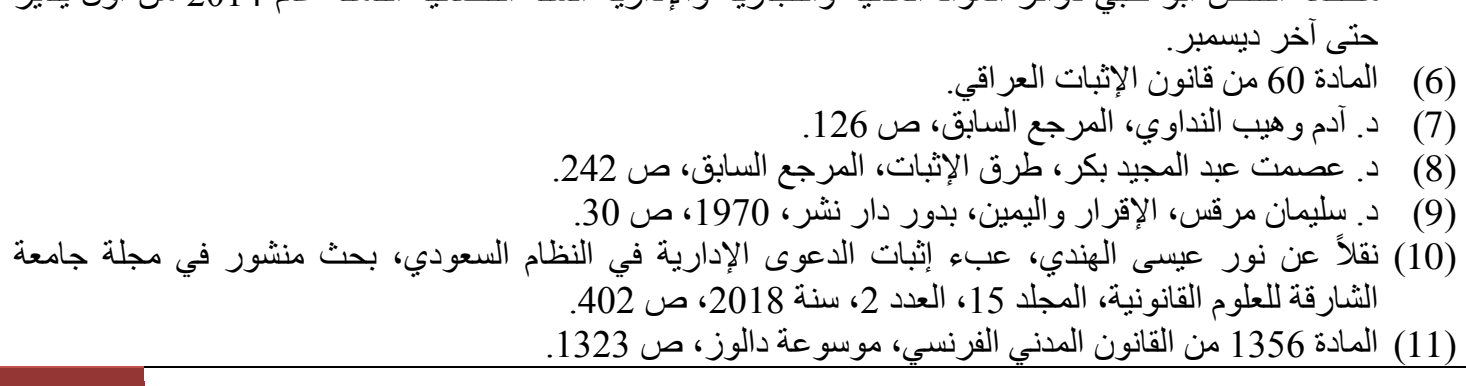


العدد (14) أغططس 2020

Volume (14) August 2020

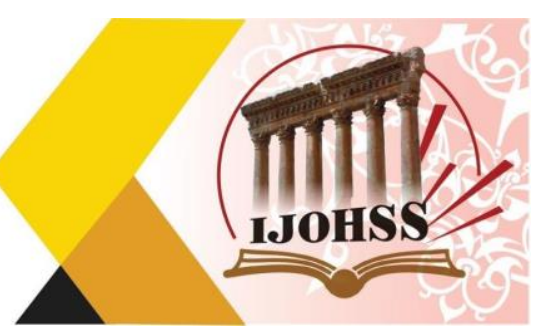

تانيًا: شروط في المقر له:1 - 1 أهلية المقز له وقبولئه:-

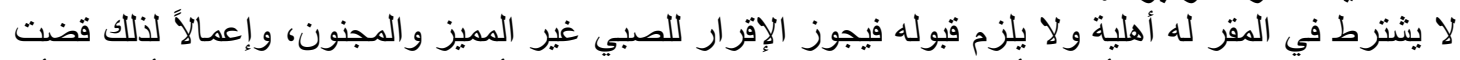

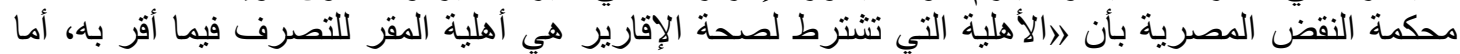

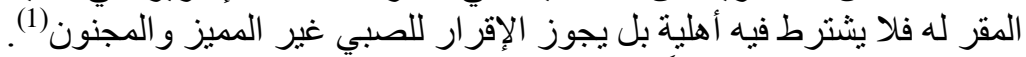

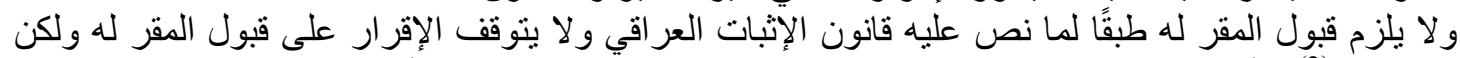

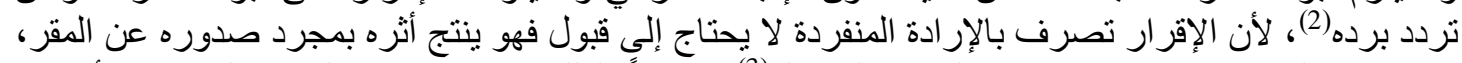

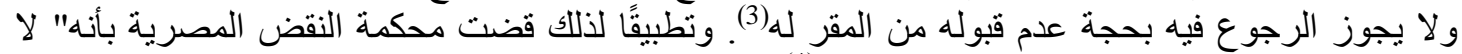

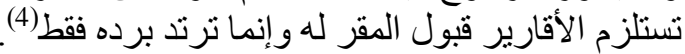

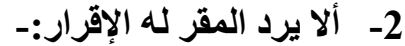

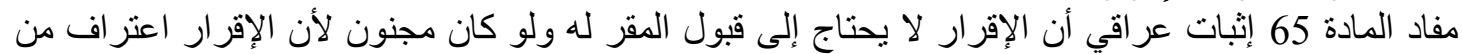

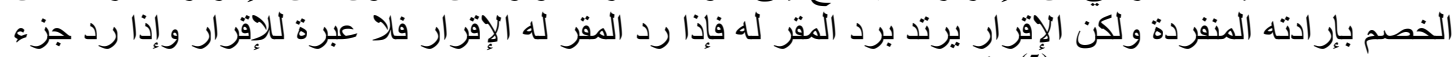

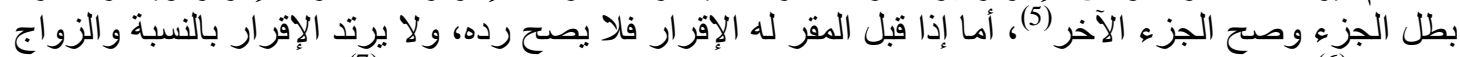

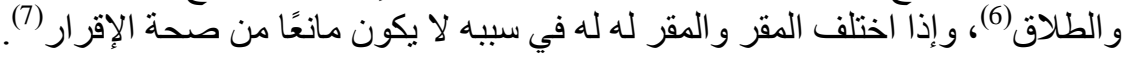

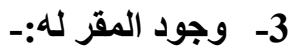

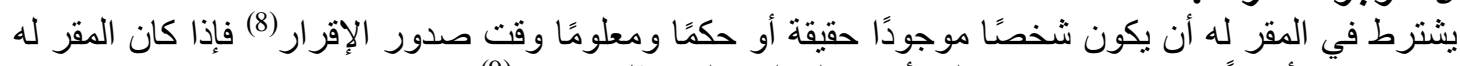

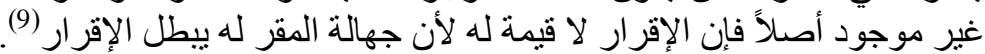

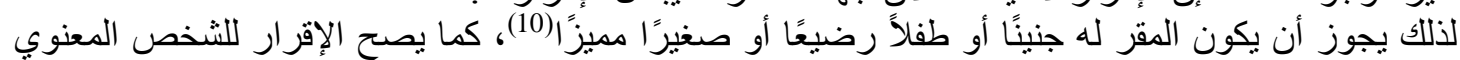

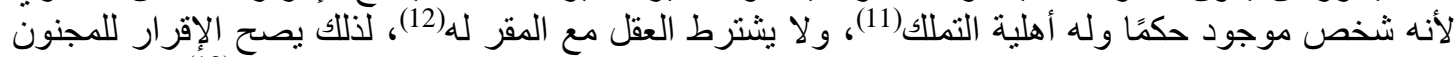

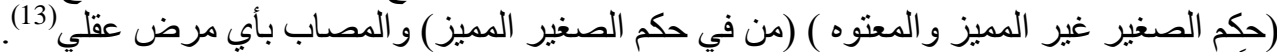

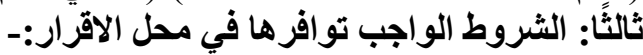

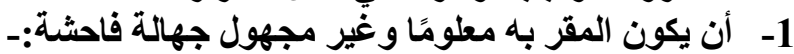

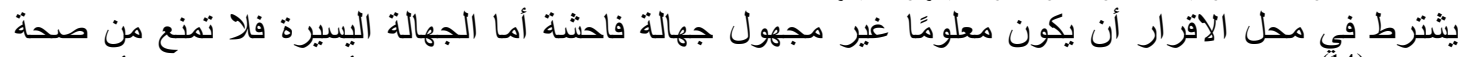

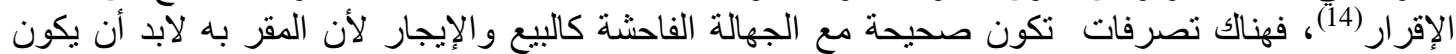

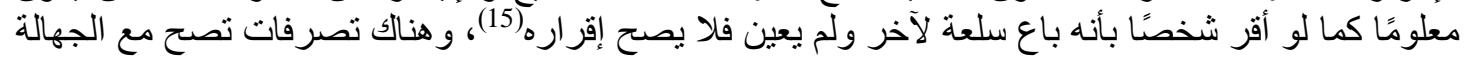

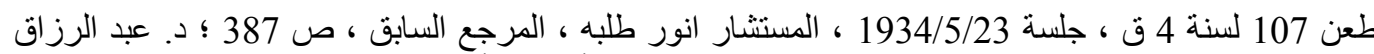

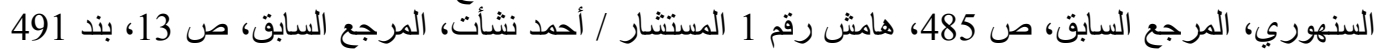

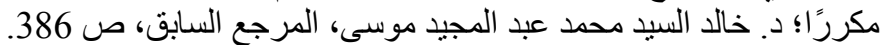

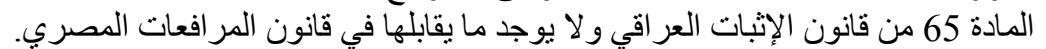

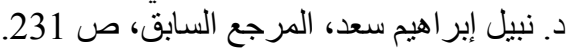

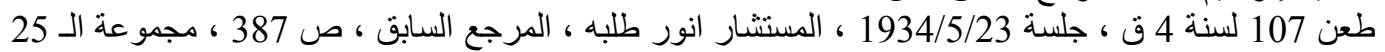

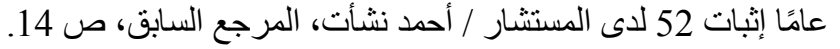

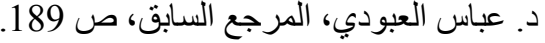

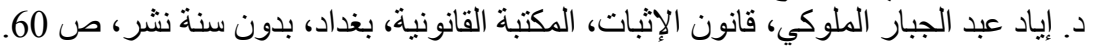

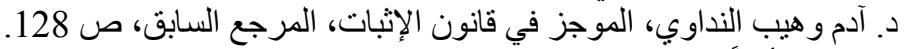

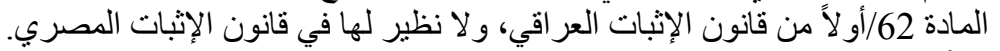

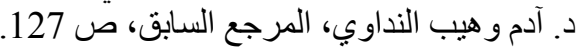

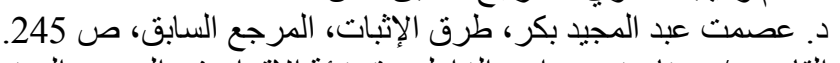

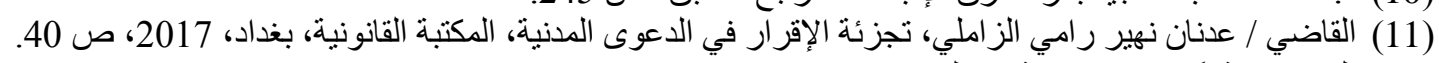

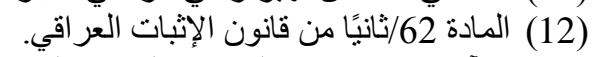

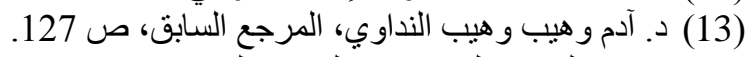


العدد (14) أغنطس 2020

Volume (14) August 2020

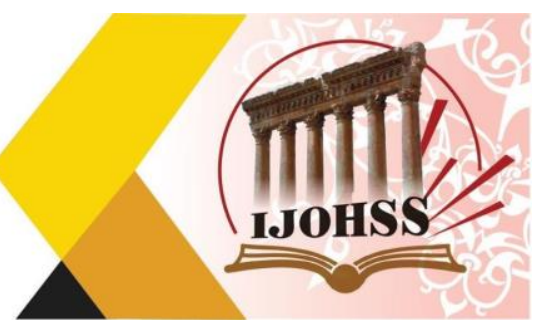

كالغصب و الوديعة فإذا أقر شخص لآخر بأنه غصب مالاً من آخر ألزم المقر بإقراره وأجبر على التعين وفي

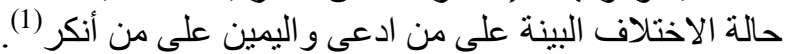
2- 2- أن يكون محل الاقرار مشروعًا:-

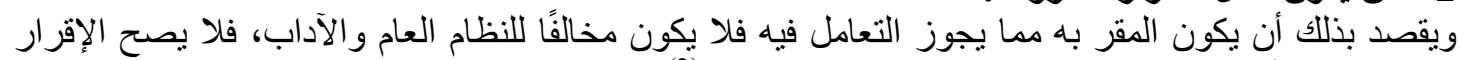

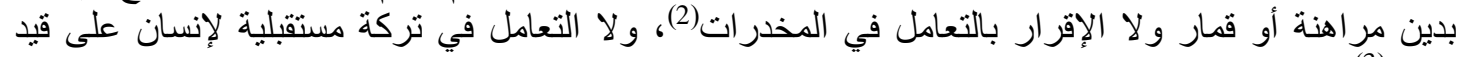

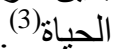
و لا يعمل بالإقرار إذا كان بأمر مخالف للنظام العام، ولو كان المقر يجهل وقت إقراره إه حكم القانون في ذللك لأن

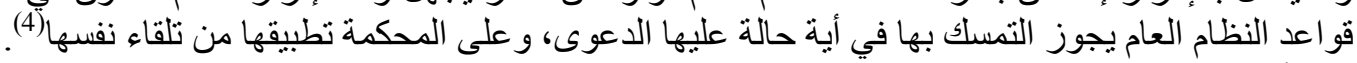

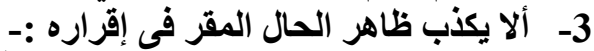

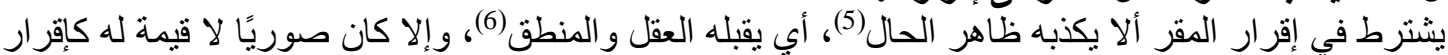

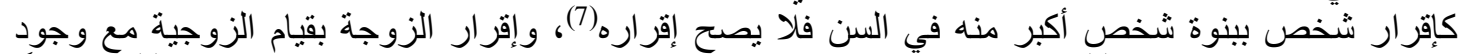

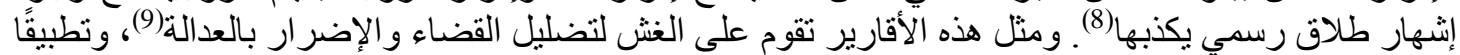

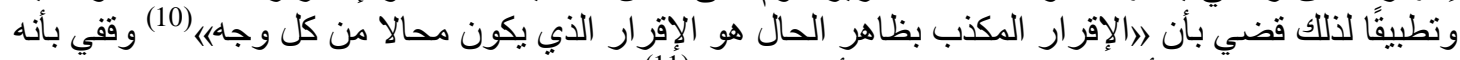

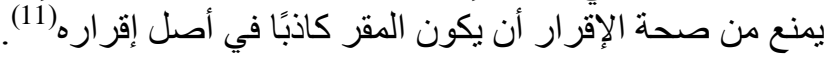

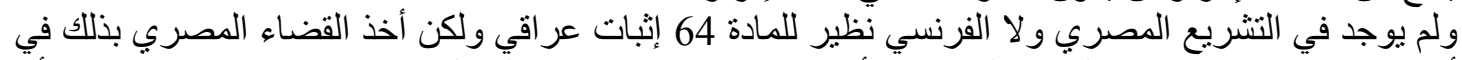

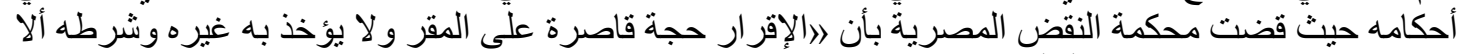

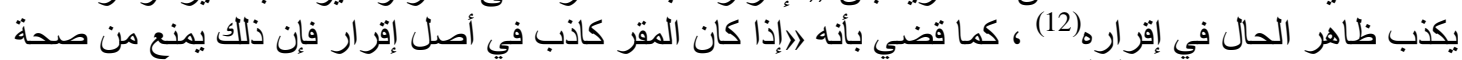

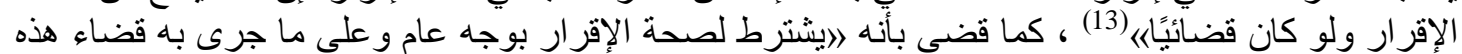

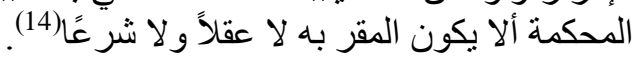

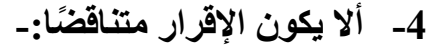

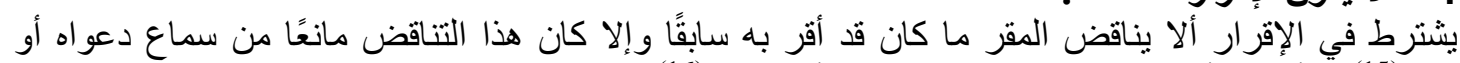

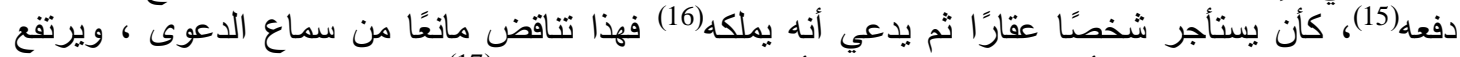

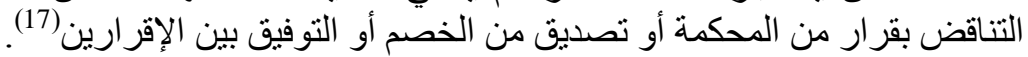

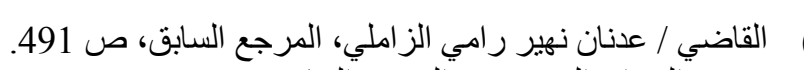

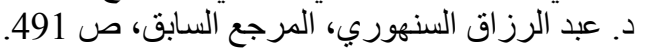

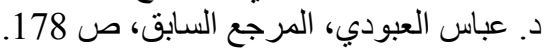

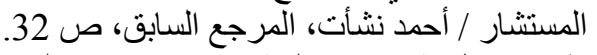

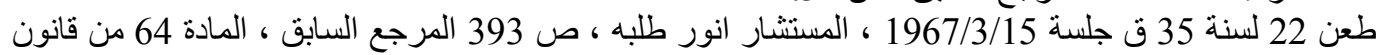
الإثبات العر اقي.

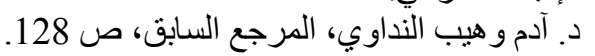

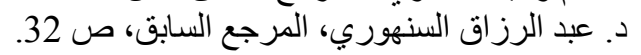

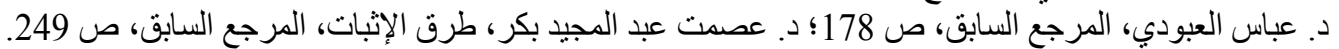

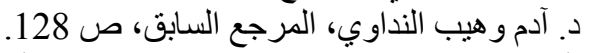

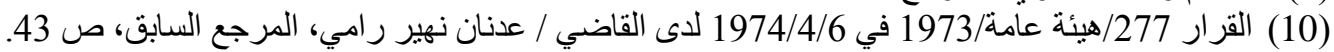

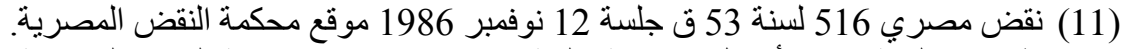

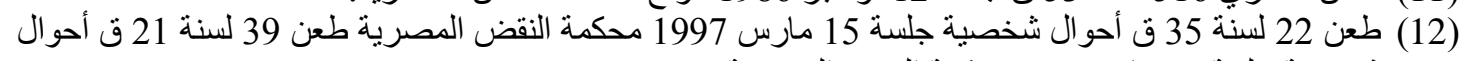

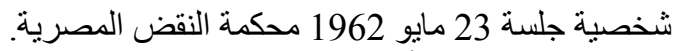

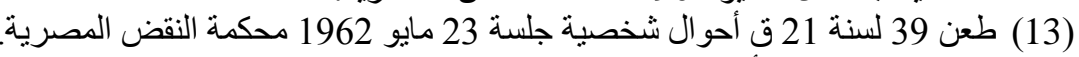

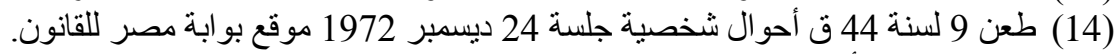

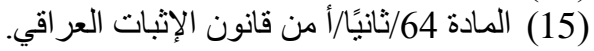

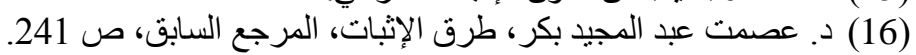
(17) المادة 64/ثانيًا/ب من قانون الإثبات العر اقيدي. 
أغسطس 2020

(14) (العدد)

ISSN: $2415-4822$

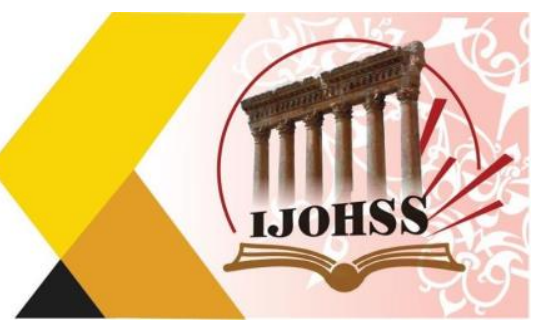

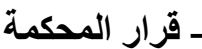

يرتفع التناقض بقر ار من المحكمة إذا صدر حكم سابق بتصديق أحد المتناقضين دون الآخر ، كأن بدعي رجل

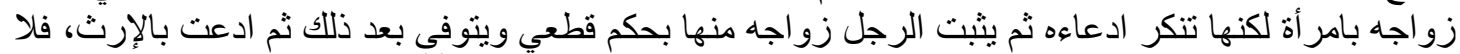

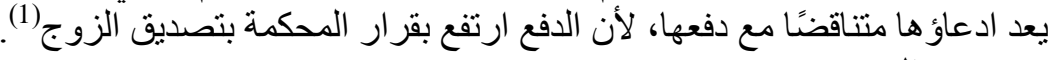

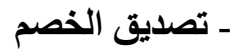

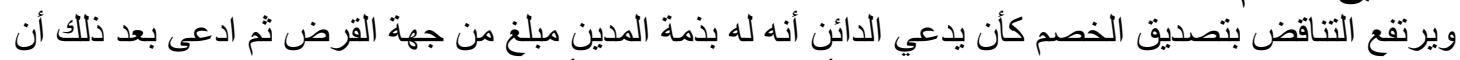

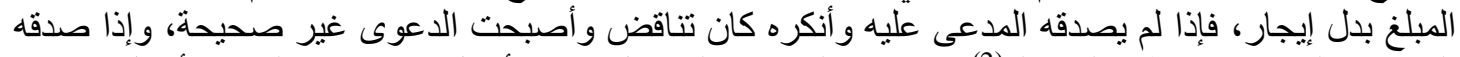

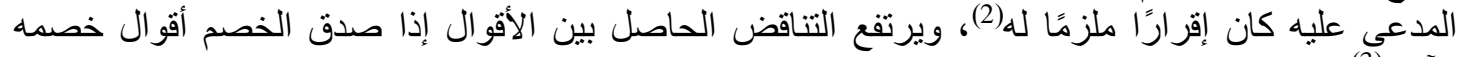

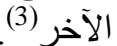

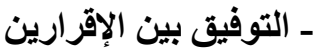

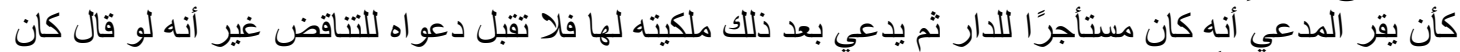

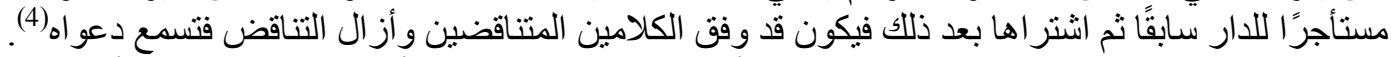

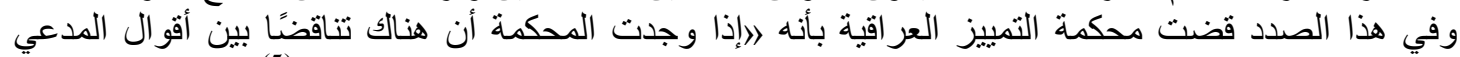

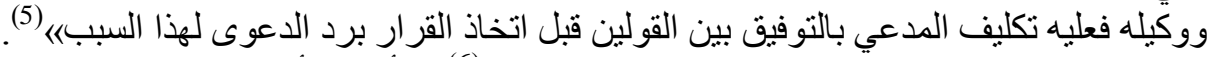

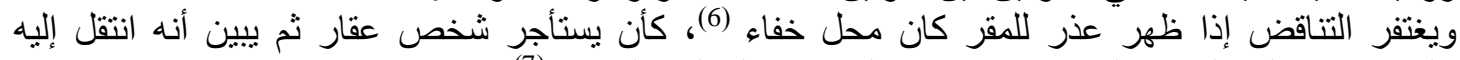

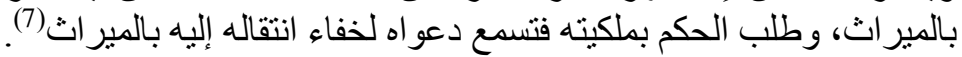

\section{المبحث الثاني \\ حجية الإقرار القضّائي}

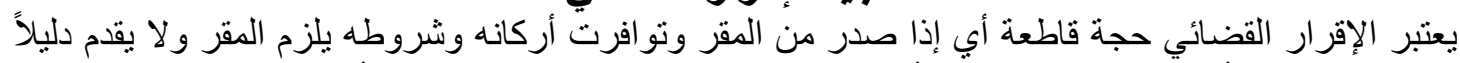

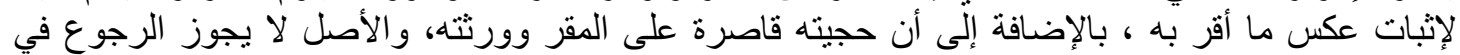

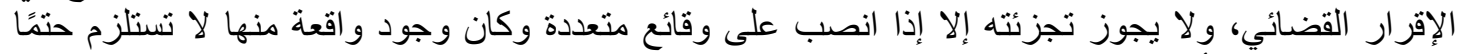

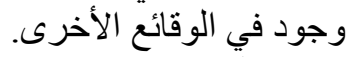
وبناء على ما سبق سوف الأفرى نقسم هذا المبحث إلى ثلاثنة مطالب كالآتي:-

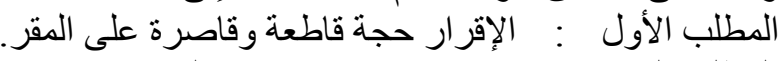

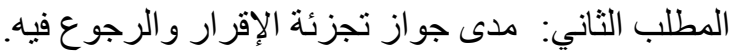

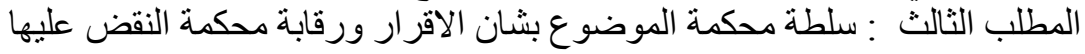

$$
\begin{aligned}
& \text { د. عباس العبودي، شرح أحكام قانون الإثبات، المرجع السابق، ص } 185 \text { وما بعدها. }
\end{aligned}
$$

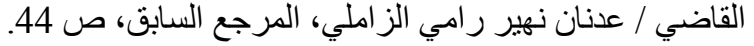

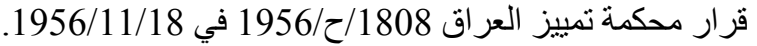

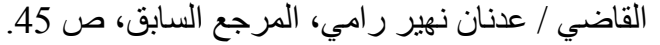

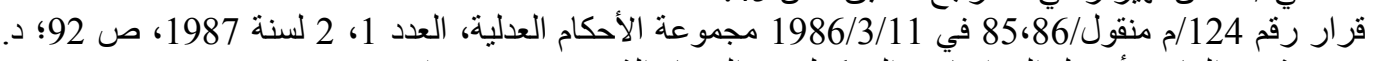

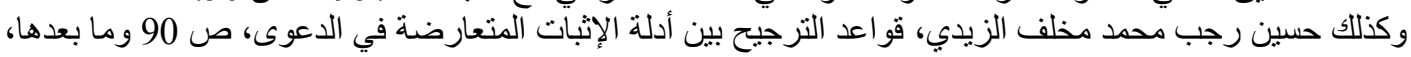

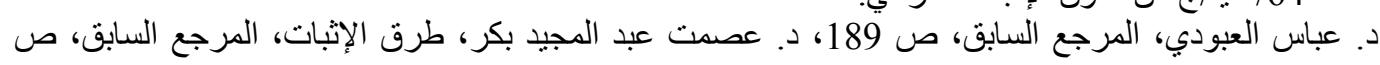




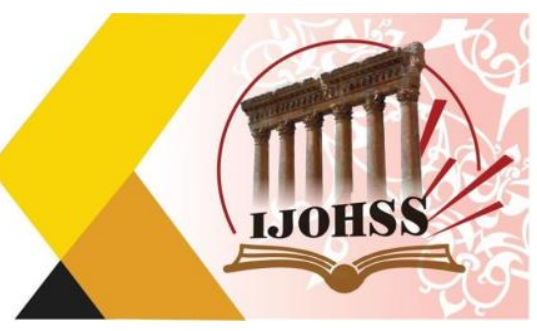

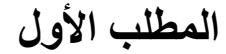

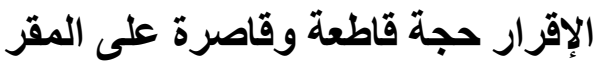

نصت قو انين الإثبات و اتفقت على أن الإقرار حجة قاطعة وقاصرة على المقر وقلى المقد استقر الفقه والقضاء على ذلك ، و عليه نقسم هذا المطلب إلى فر عين:-

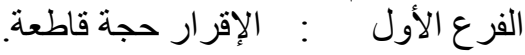
الفرع الأول الأول الفرع الثاني الإقرار حجة قاصرة على المقر.

\section{الإقرار حجة قاطعة الأول}

تتص المادة 114 إثبات مصري على أن 》الإقرار حجة قاطعة على المقر) ويقابل هذا النص المادة 67 إثبات

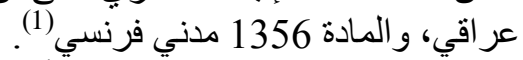

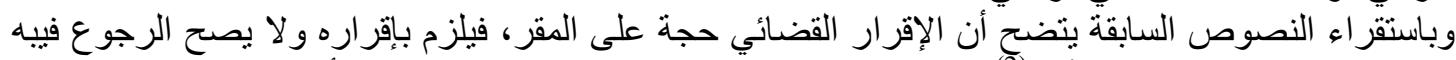

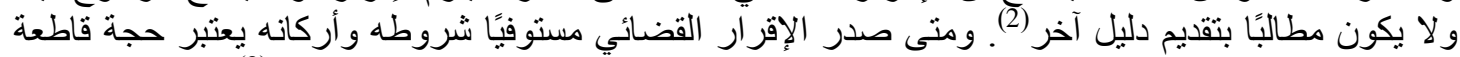

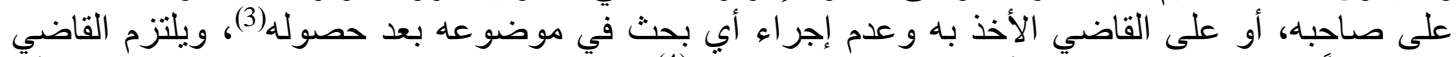

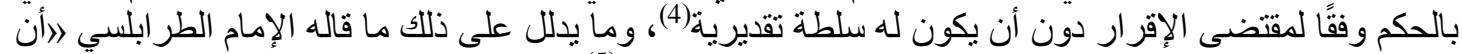

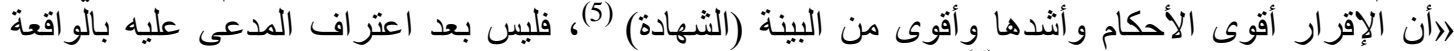

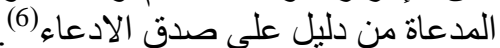

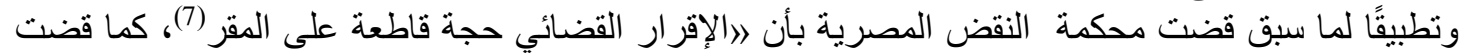

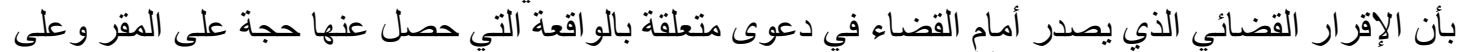

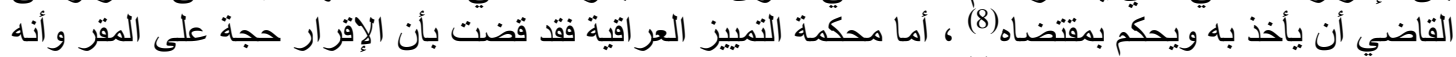

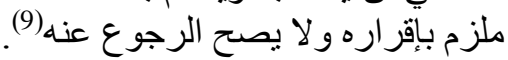

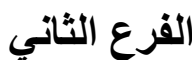

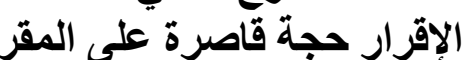

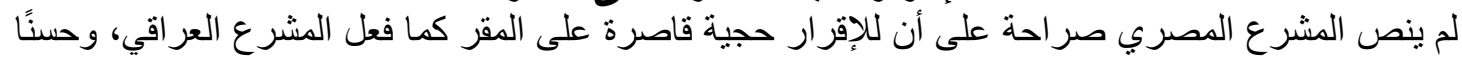

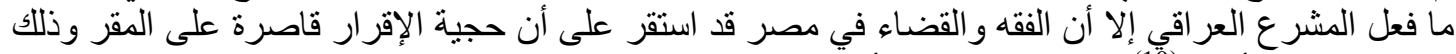

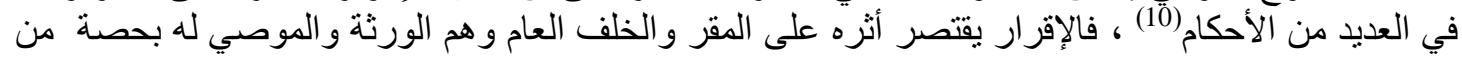

و المادة 53 إثبات إمار اتي و المادة 67 إثبات عر اقي قبل التعديل كانت 》الإقرار حجة قاطعة وقاصرة على المقر ونم

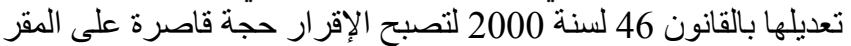

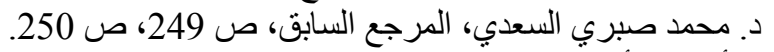

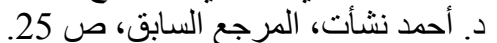

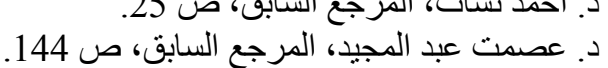

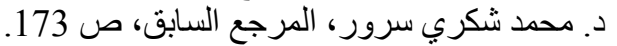

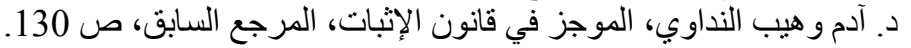

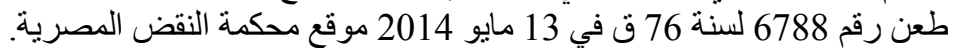

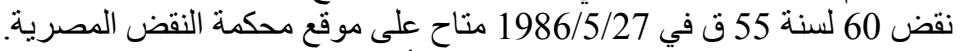

وكذلك منشور في مجموعة المستثار / سعيد أحمد شعله، قضاء النقض في في الإثبات، منشأة المعارف، اسكندرية،

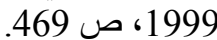

www.iraqia.org

(9) قرار رقم 2690 في 2008/11/10 منشور على الموقع الإلكتروني للسلطة القضـاء العر اقية:

(10) حيث قضي بأن حجية الإقرار وفقًا لنص المادة 104 إثبات قاصرة على المقر ، طعن رقم 2296 لسنة 51 ق في

1989/2/28 موقع محكمة النقض المصرية. 


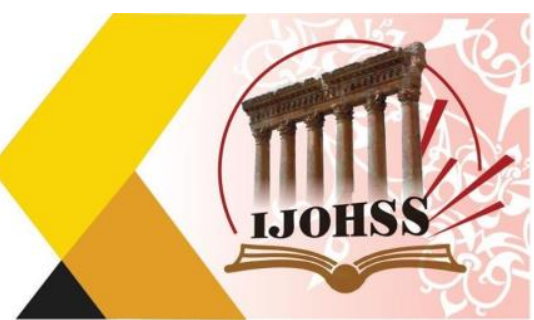

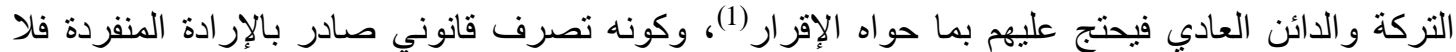

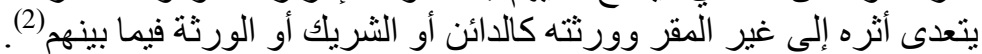

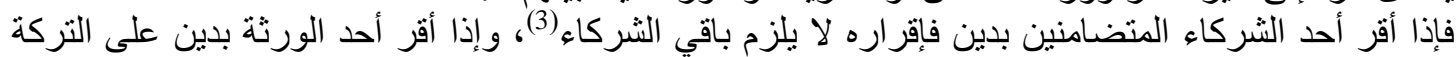

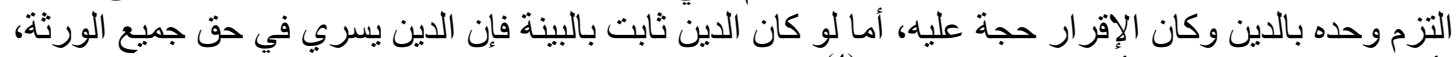

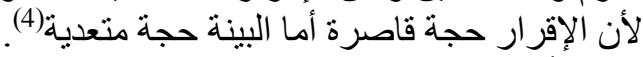

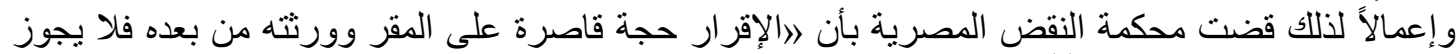

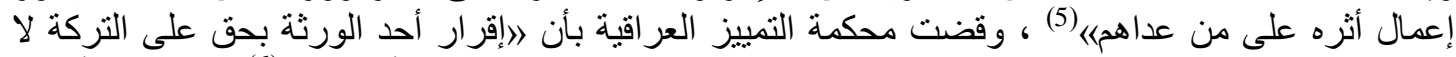

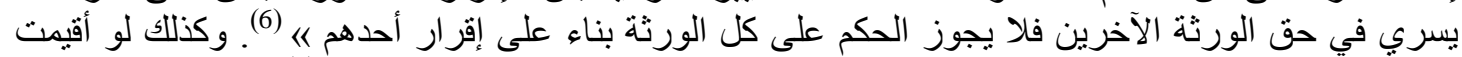

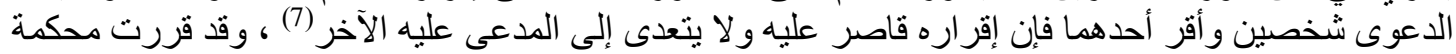

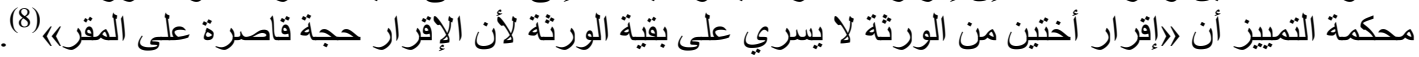

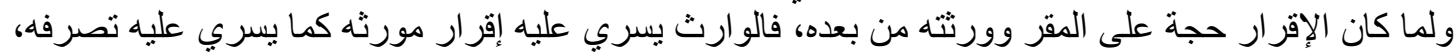

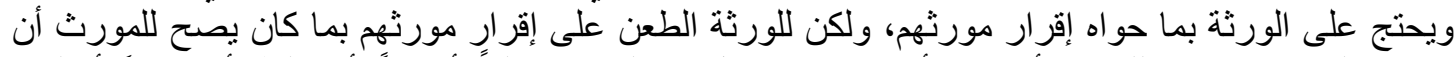

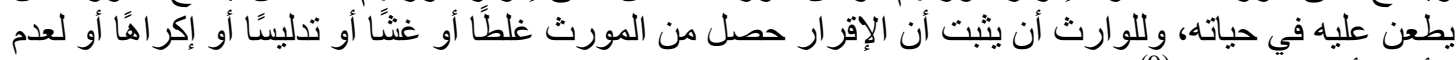

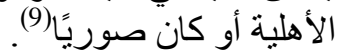

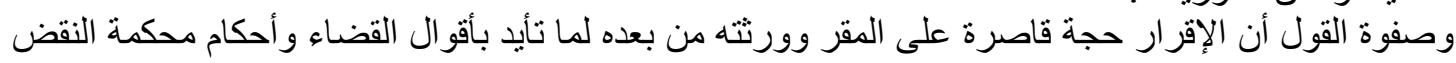

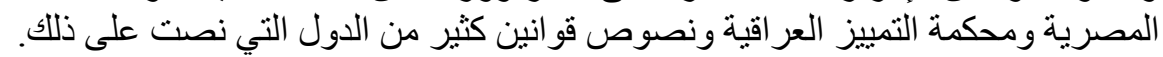

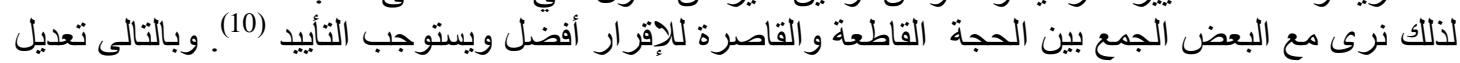

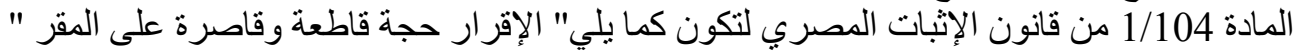

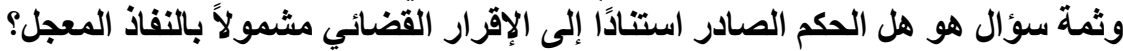

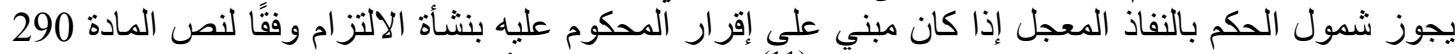

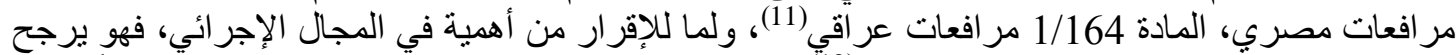

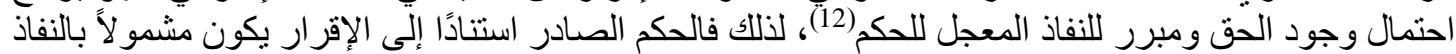

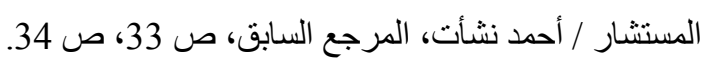

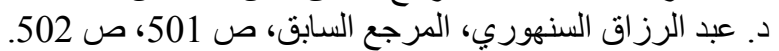

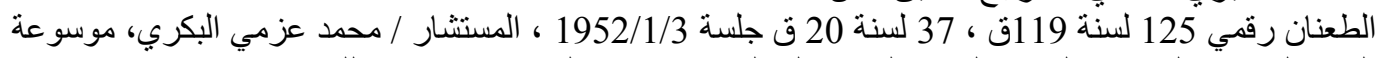

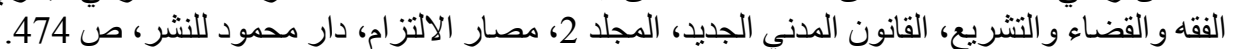

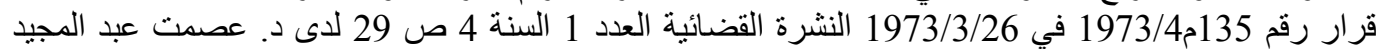

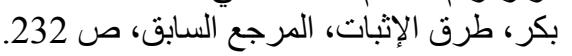

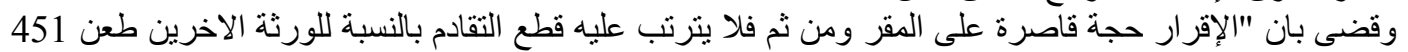

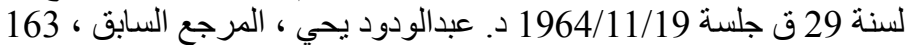

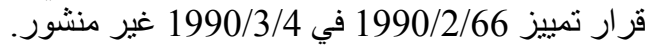

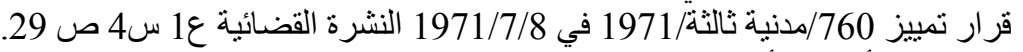

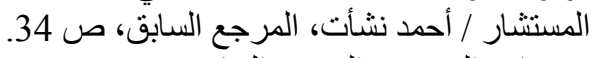

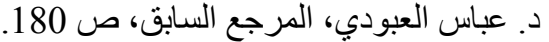

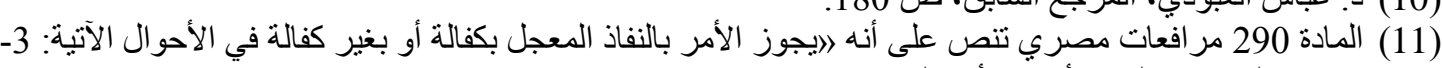

إذا كان المحكوم عليه قد أقر بنثأة الالتزام.

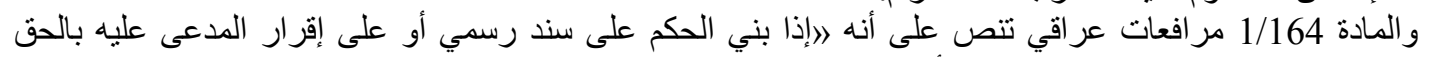

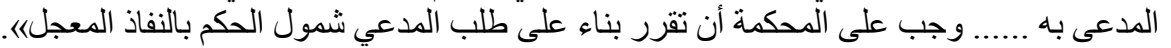

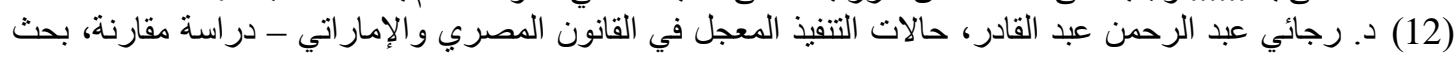

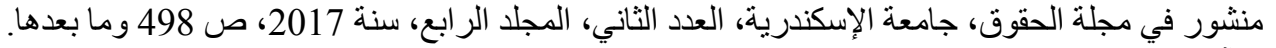

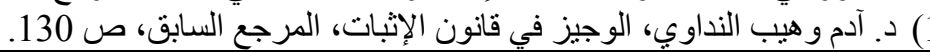


أغسطس 2020

العدد (14)

ISSN: $2415-4822$

Volume (14) August 2020

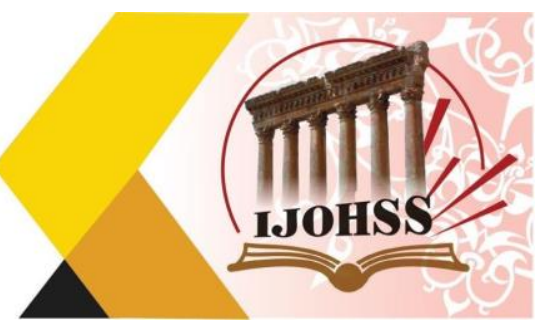

$$
\begin{aligned}
& \text { المطلب الثاني }
\end{aligned}
$$

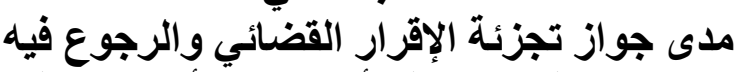

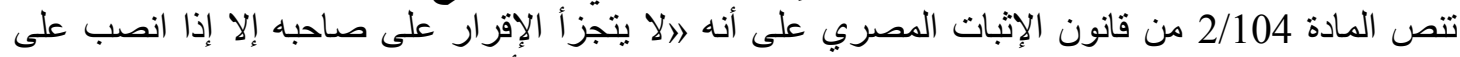

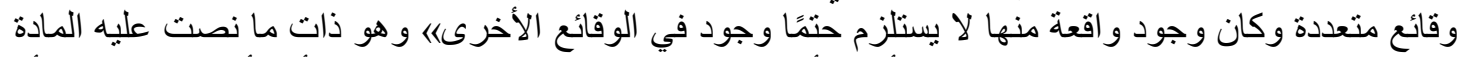

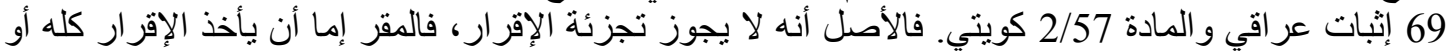

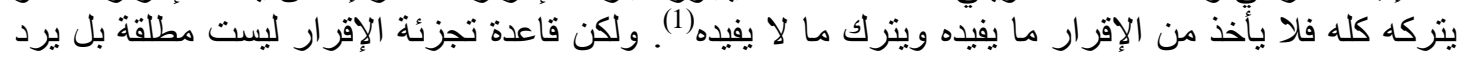

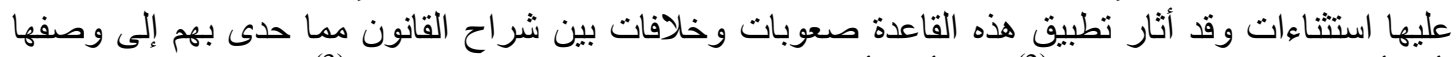

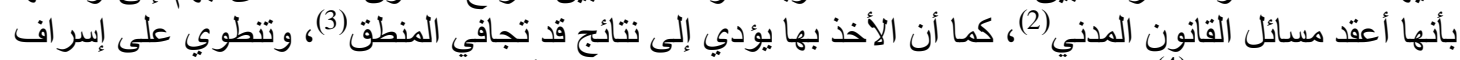

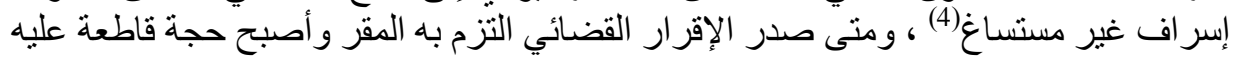

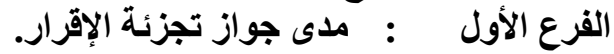

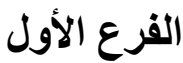
الفرع الثاني المى جواز الرجوع في الإثرار

\section{مدى جواز تجزئة الإقرار}

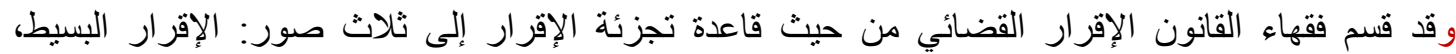

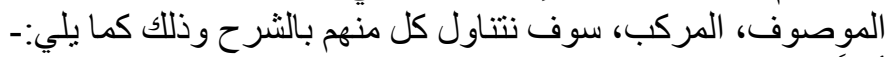

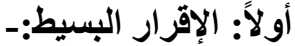

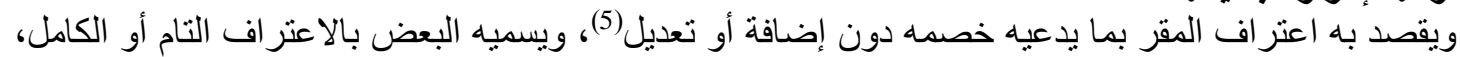

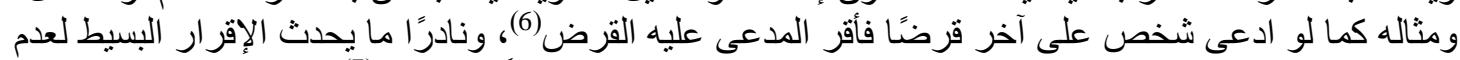

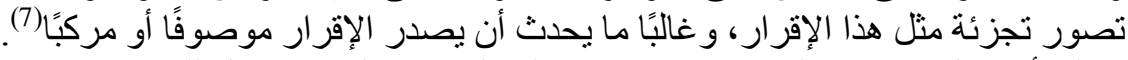

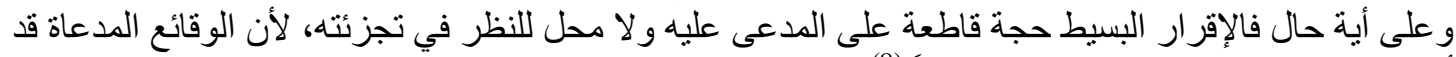

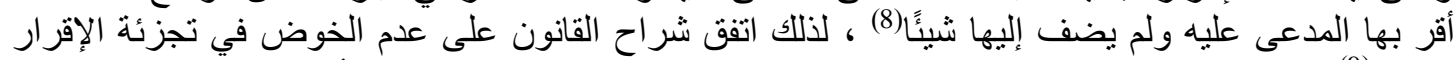

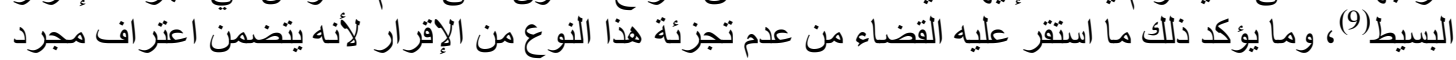

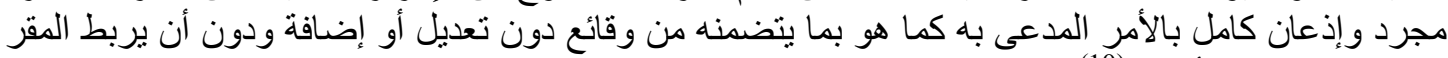
هذا الإقر ار بو اقعة أخرى بـ (10).

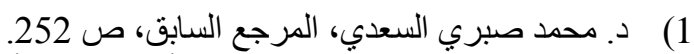

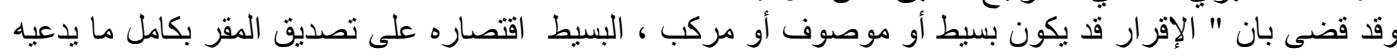

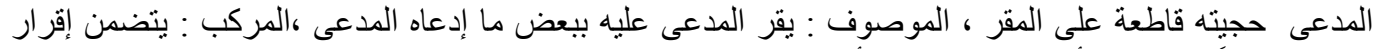

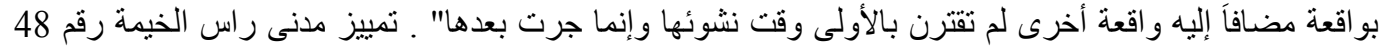

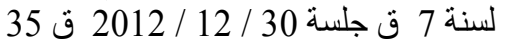

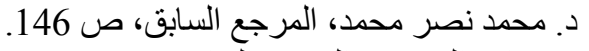

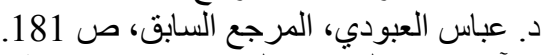

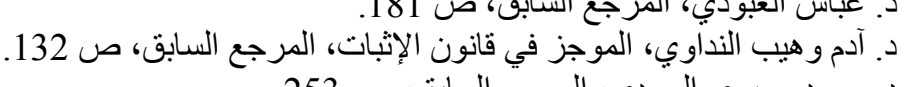

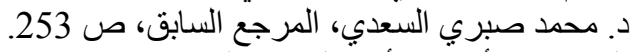

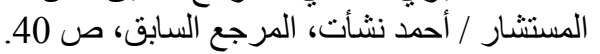

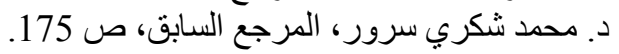

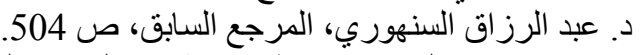

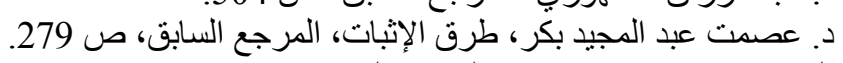

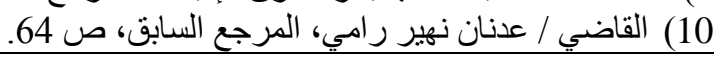


العدد (14) أغنطس 2020

Volume (14) August 2020

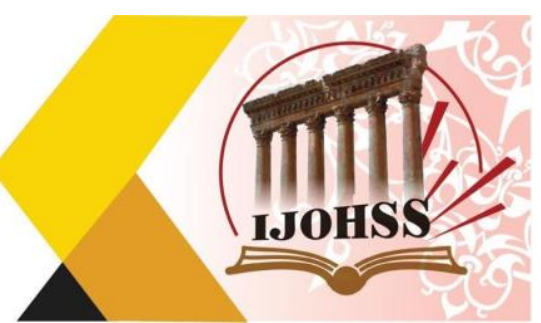

تانياً : الإقرار الموصوف:-

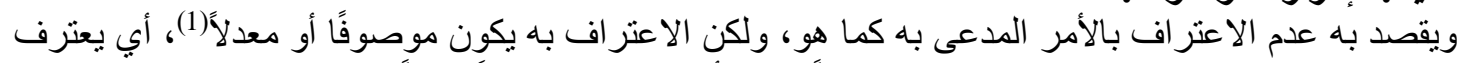

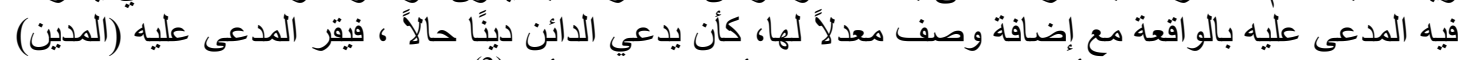

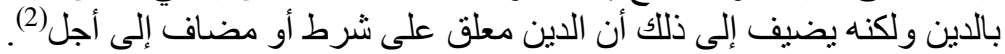

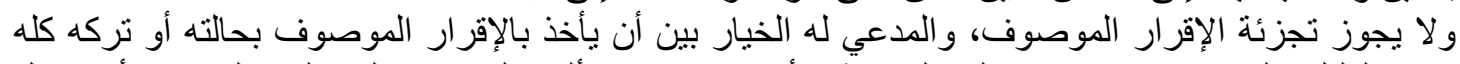

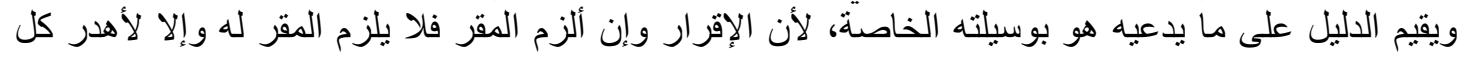

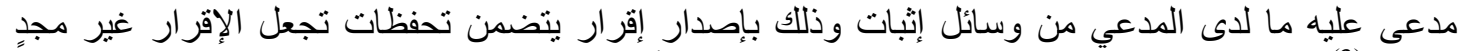

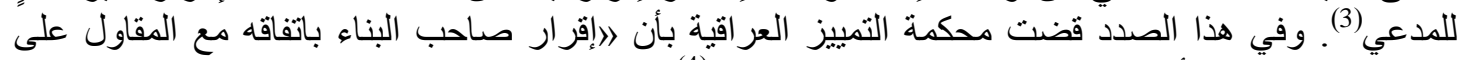

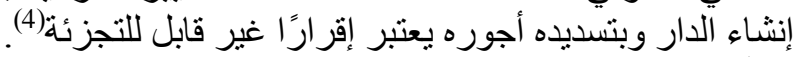

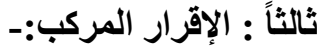

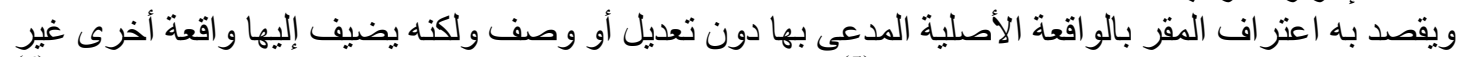

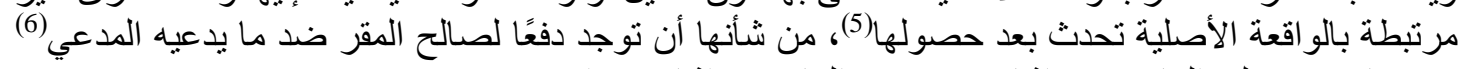

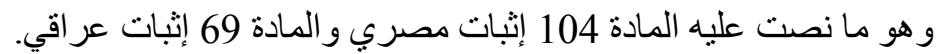

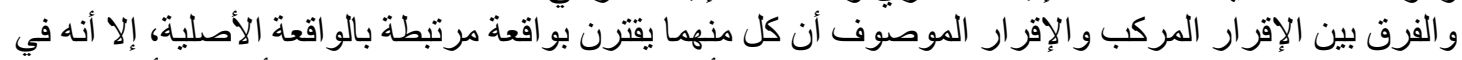

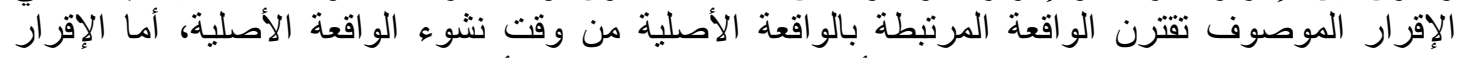

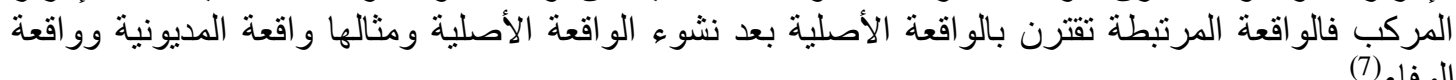
فإذا كانت الو اقعة الثنانية مرتبطة بالو اقعة الأصلية(8)، أو كانت الواقوانة الوانة المرتبطة النتيجة العادية أو العرضية

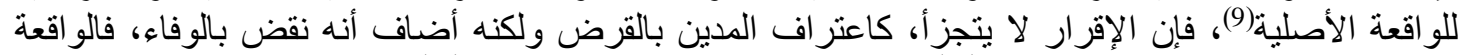

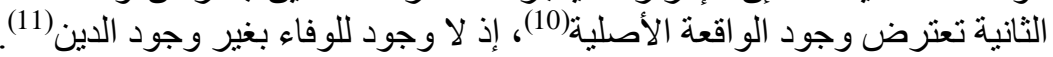

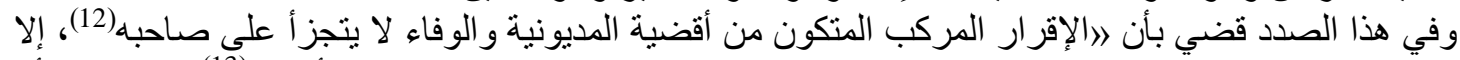

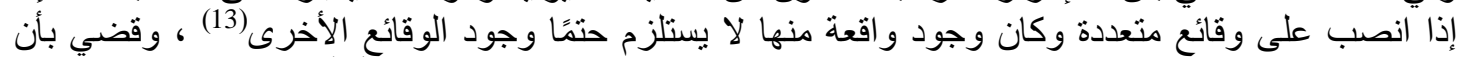

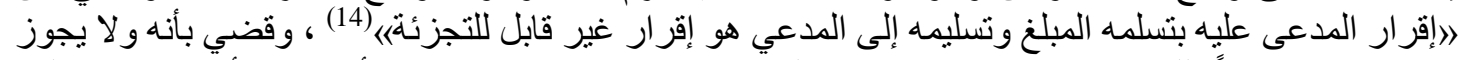

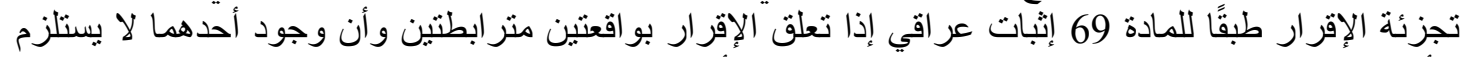

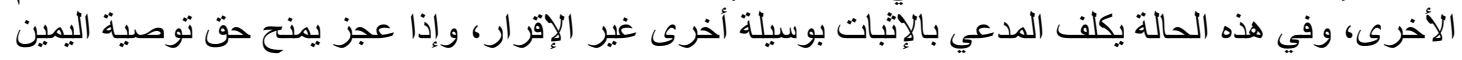

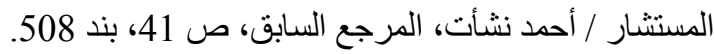

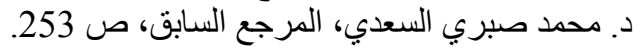

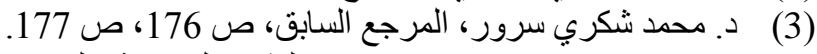

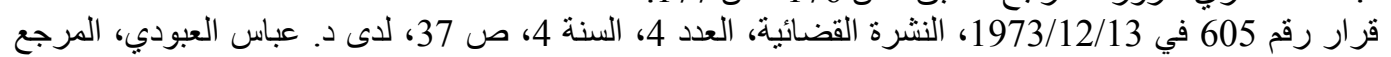

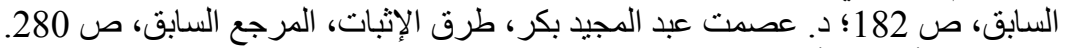

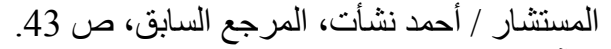

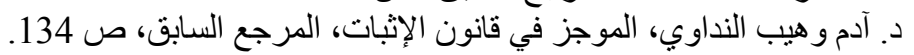

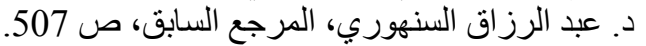

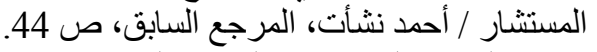

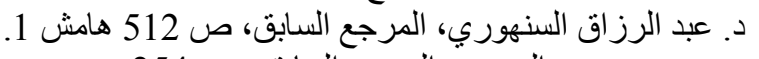

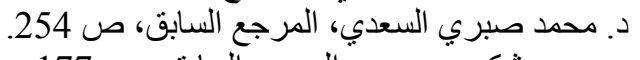

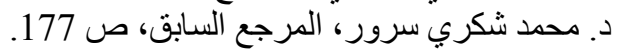

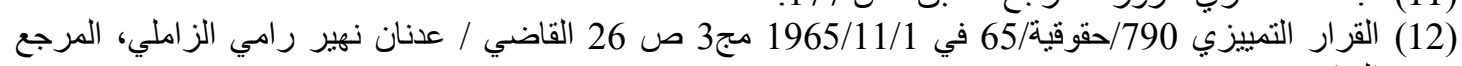
السابق، صنار التبيزي.

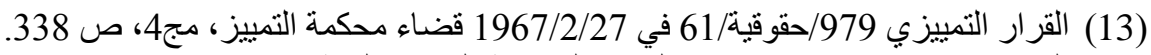

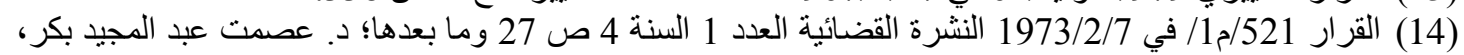

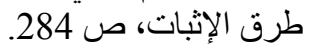




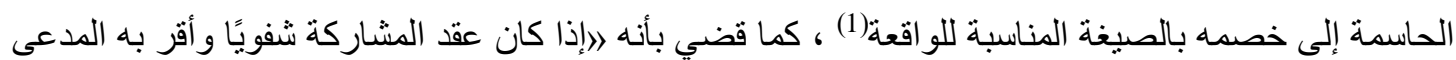

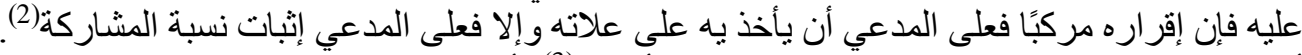

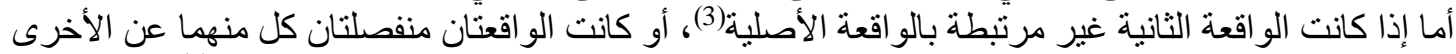

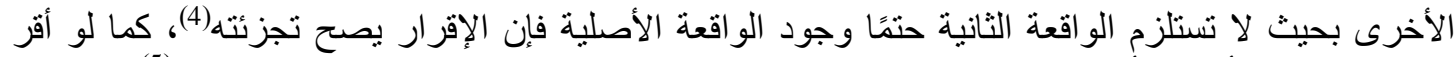

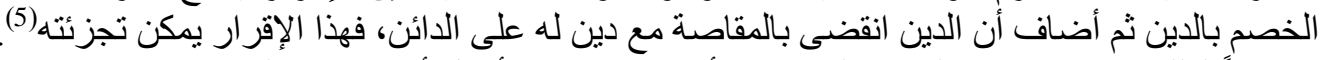

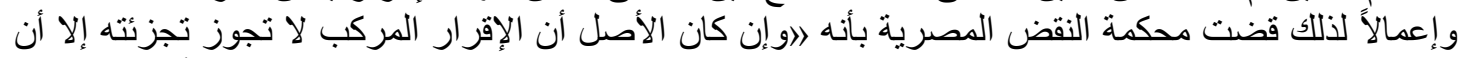

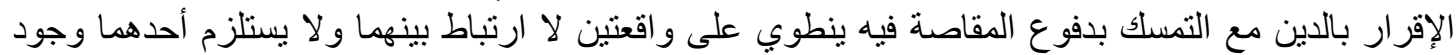

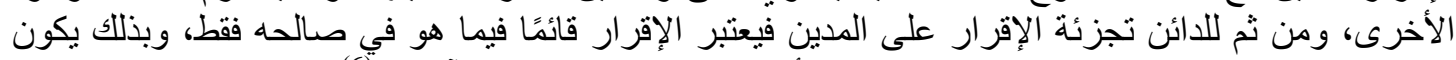

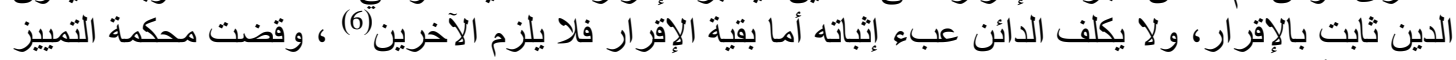

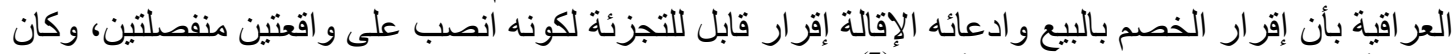

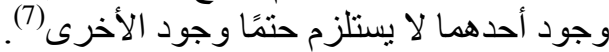

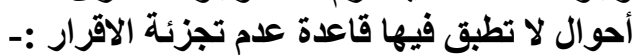

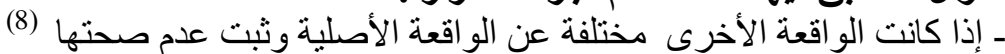

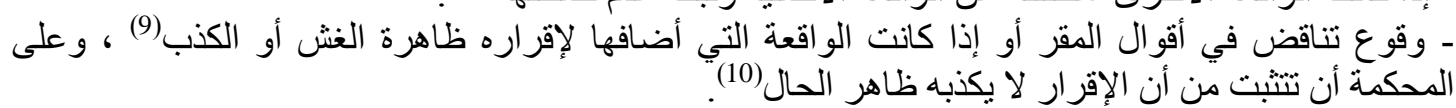

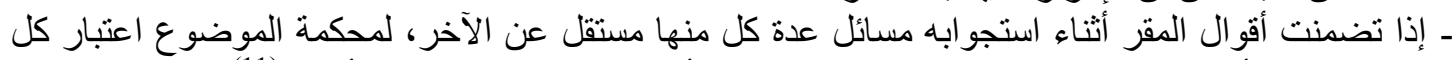

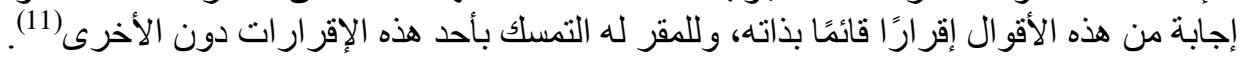

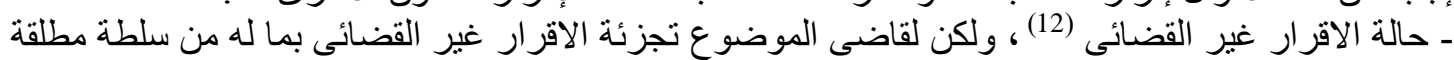

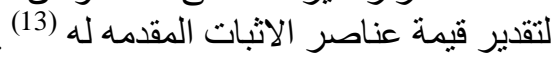

\section{مدى جواز الرجوع في الإقرار القضائي}

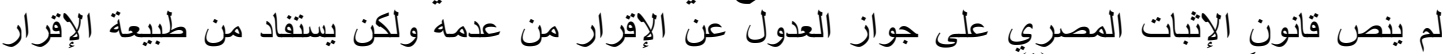

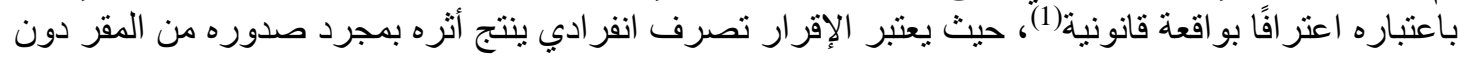

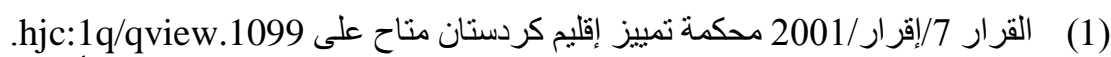

Hjc.1q/qview.3971

$$
\text { القرار 1/329/الإقرار المركب/2008 في 2008/4/14 متاح على موقع القضاء الأعلى: }
$$

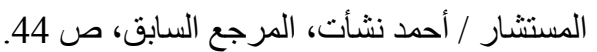

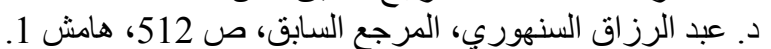

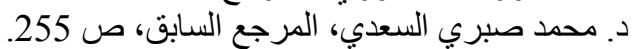

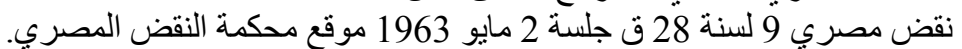

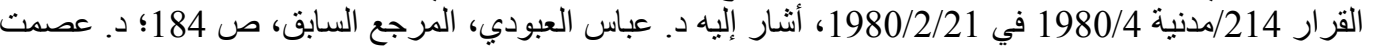

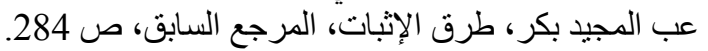

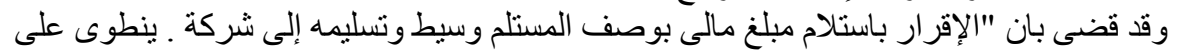

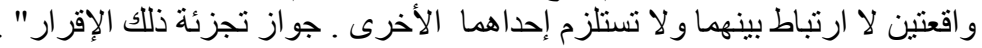

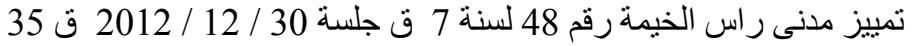

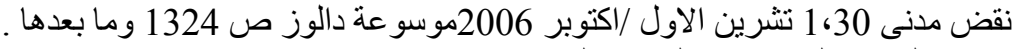

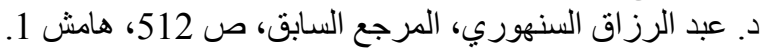

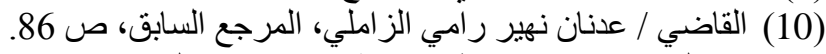

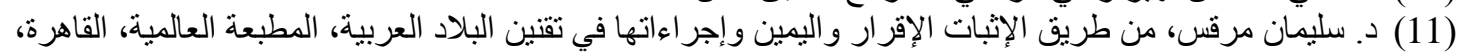

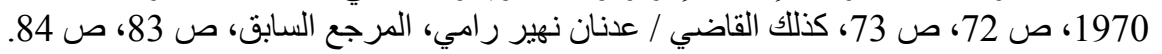

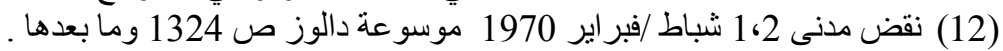

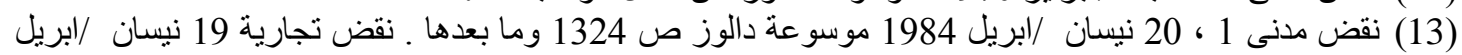

1985 موسو عة دالوز ص نب 1324 وما بعدهان 


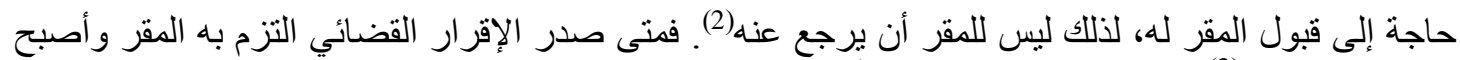

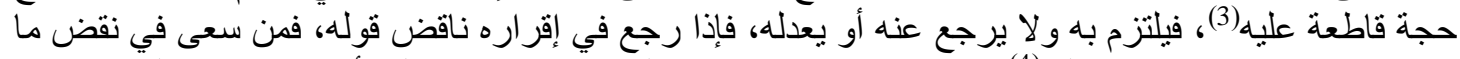

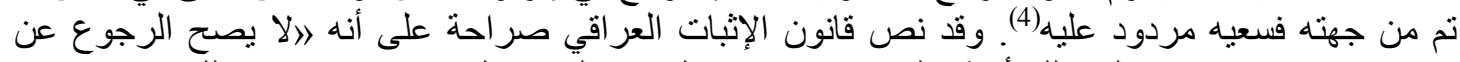

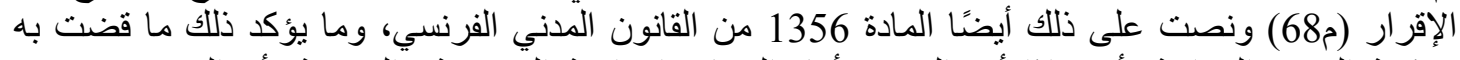

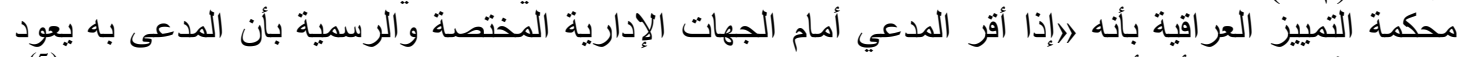

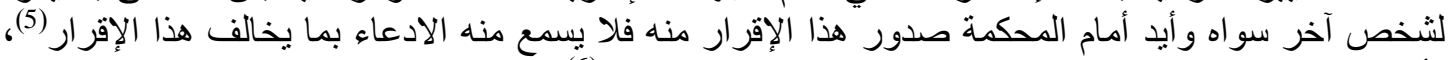

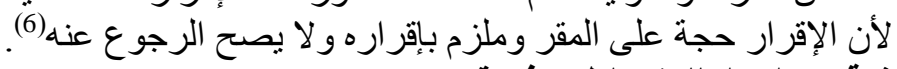

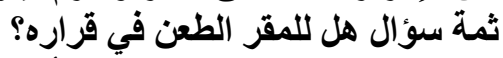

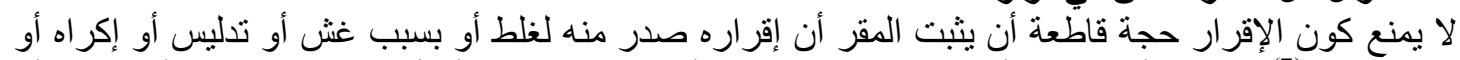

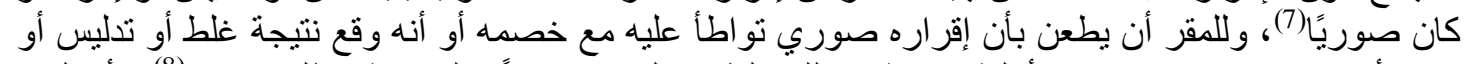

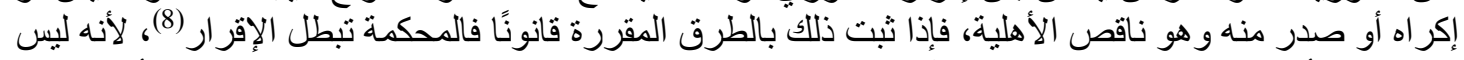

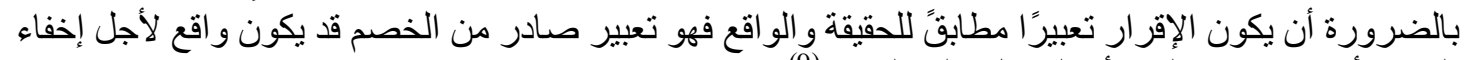

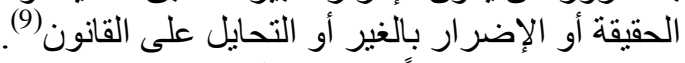

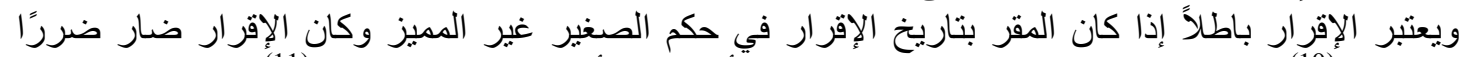

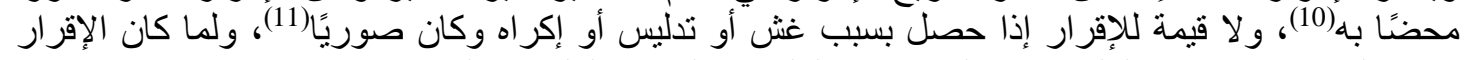

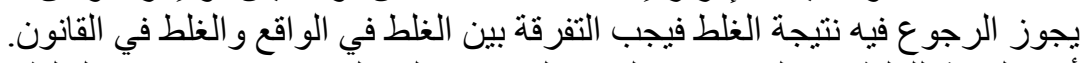

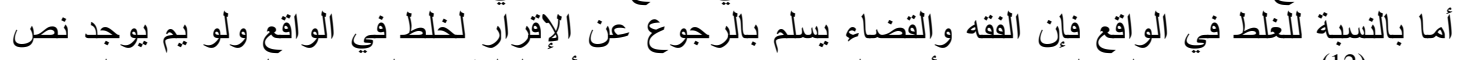

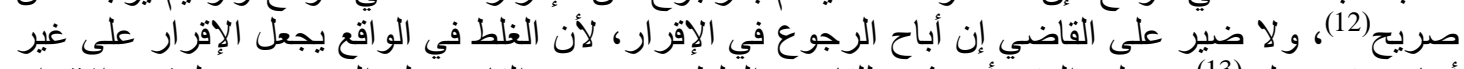

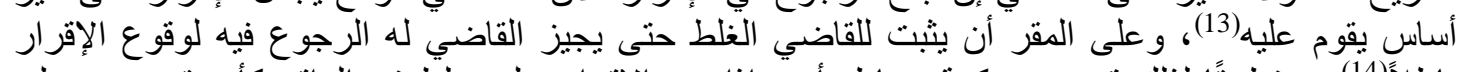

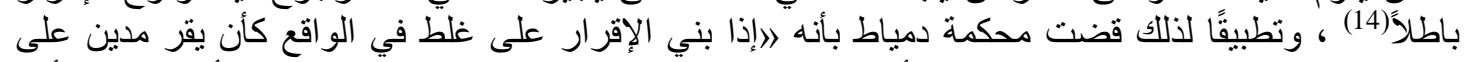

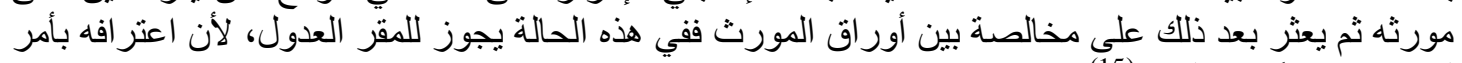
لم يكن موجودًا في الو اقع (15).

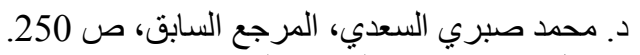

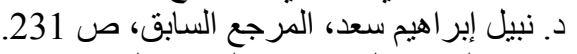

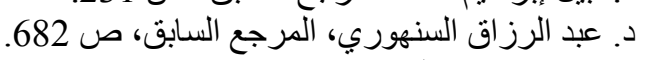

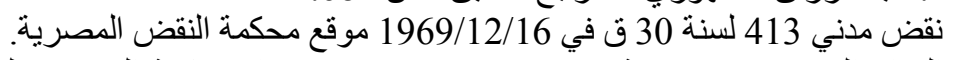

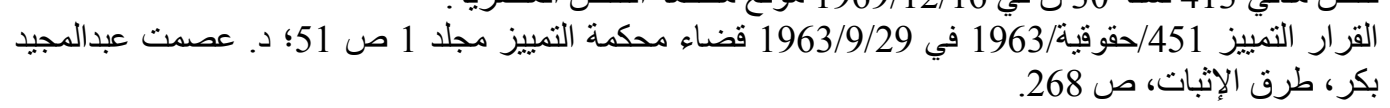

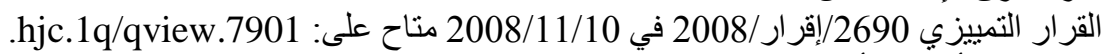

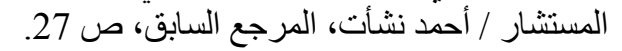

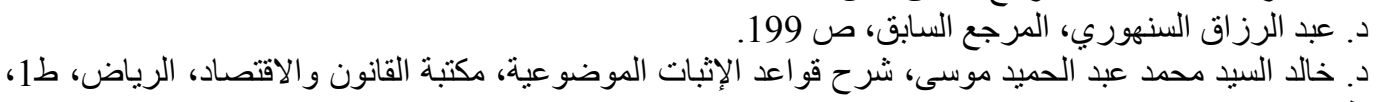

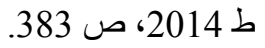

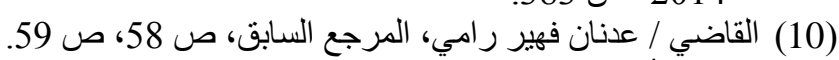

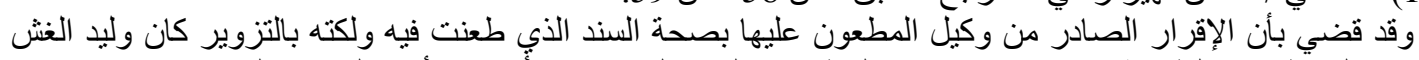

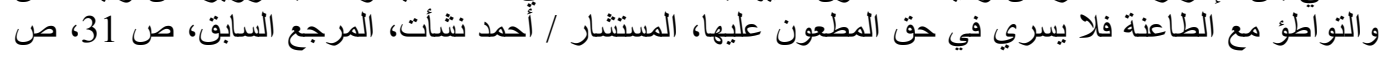




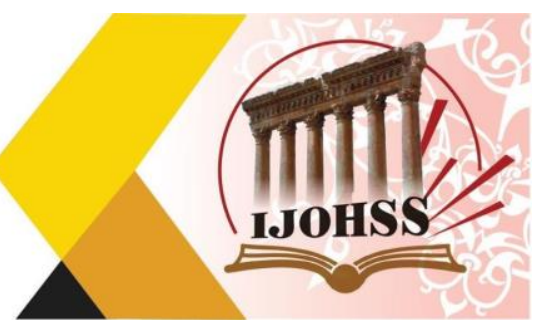

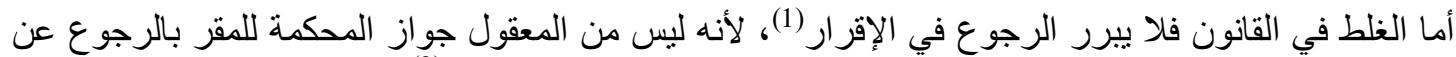

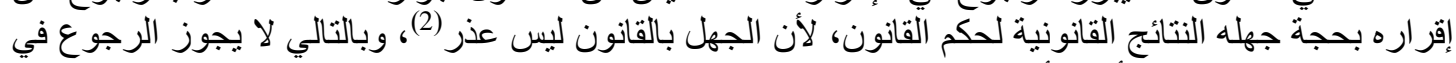

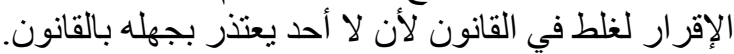

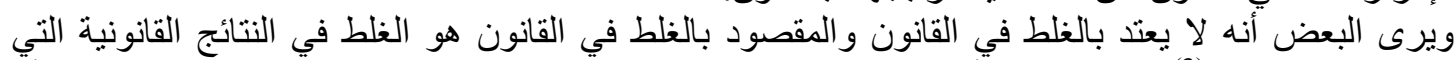

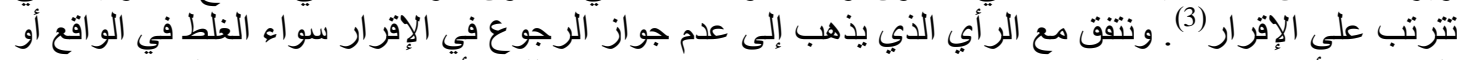

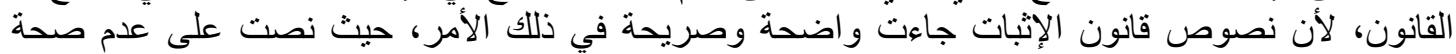

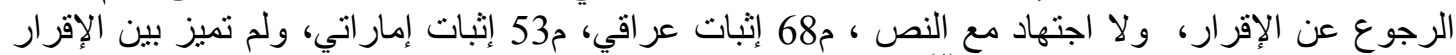

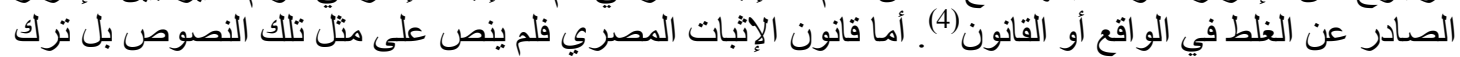

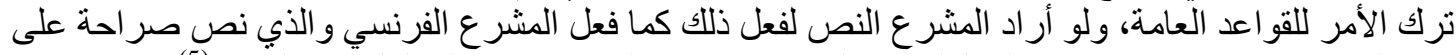

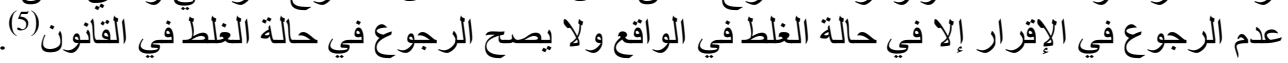

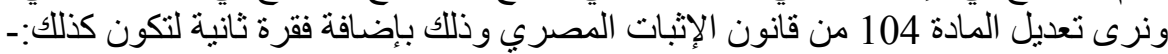
2 - و لا يصح الرجوع عن الإقرار إلإنل لغلط جوهري.

\section{المطلب الثالث}

سلطة محكمة الموضوع بشان الاقرار ورقابة محكمة النقض عليها

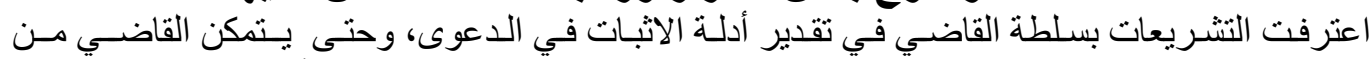

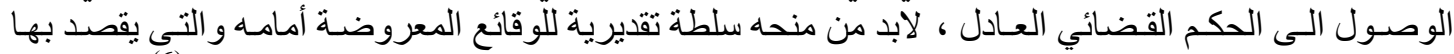

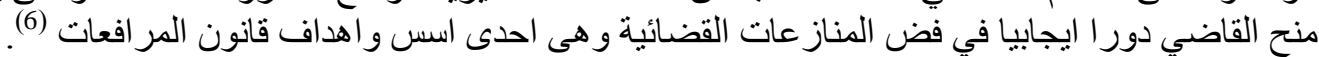

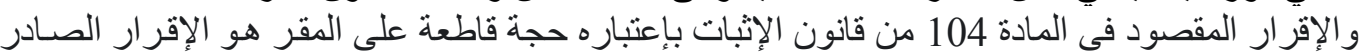

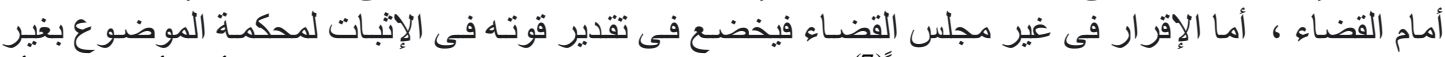

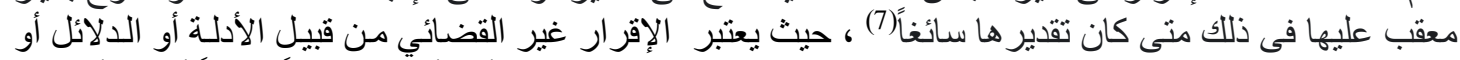

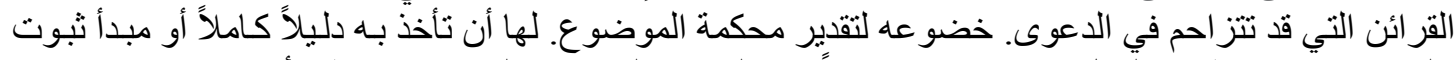

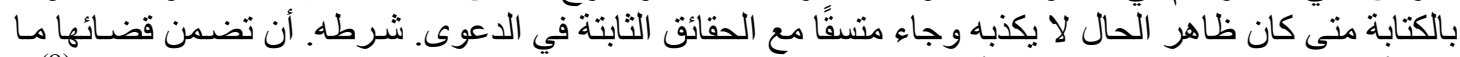

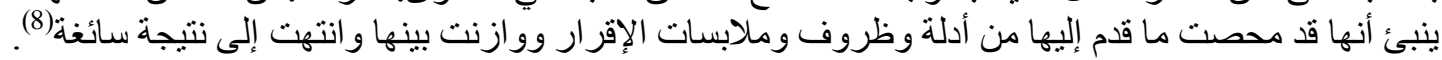

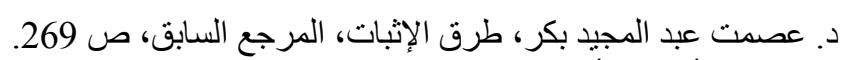

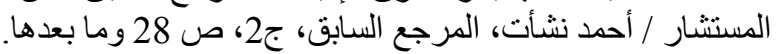

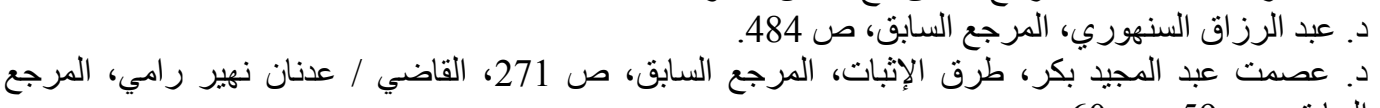

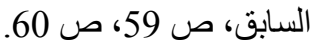

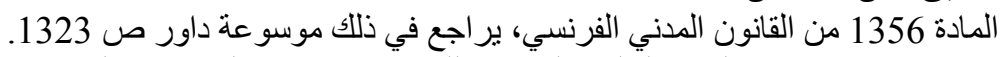

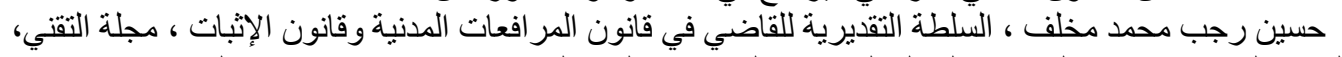

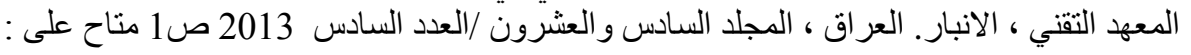
https://www.iasj.net/iasj?func=fulltext\&aId=136390

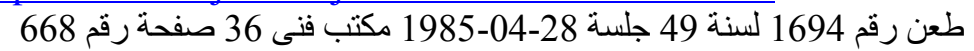

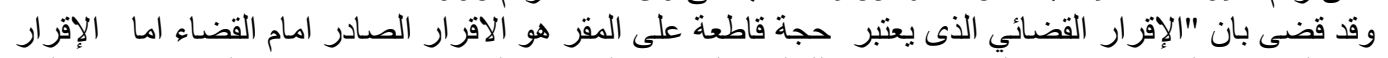

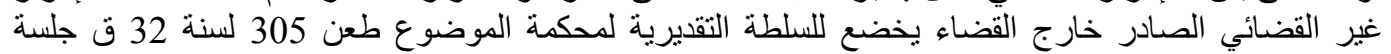

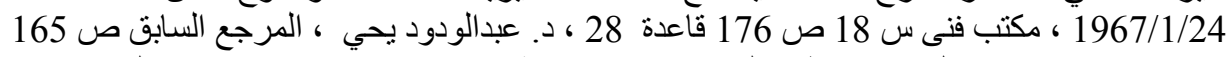

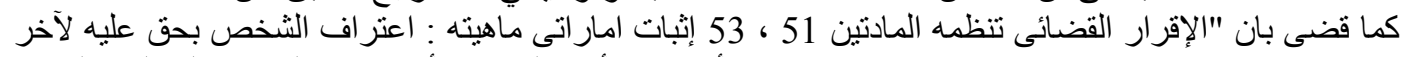

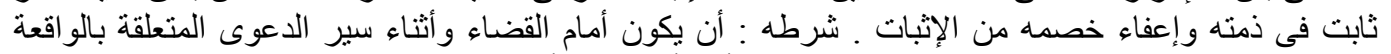

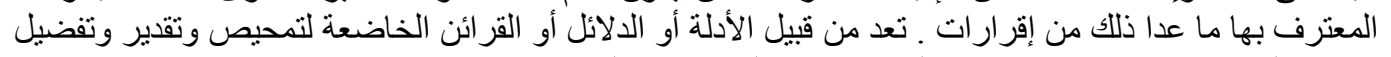

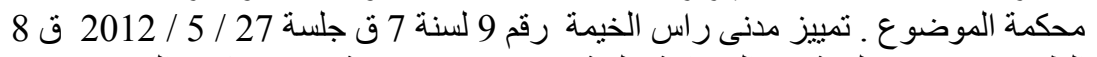

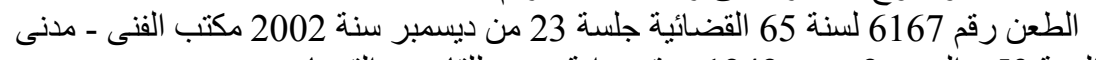

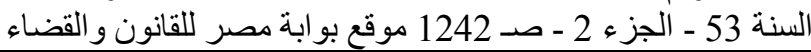


العدد (14) أغططس 2020

Volume (14) August 2020

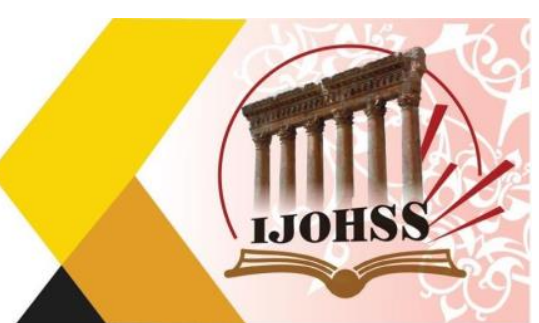

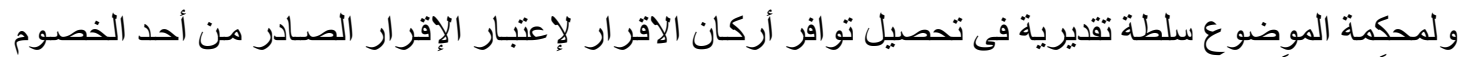

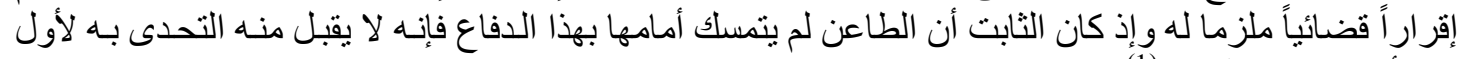

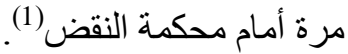

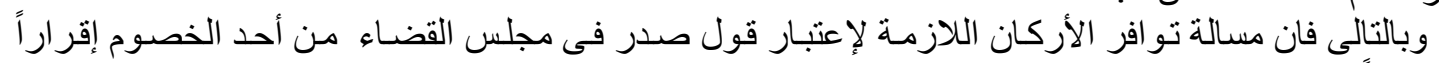

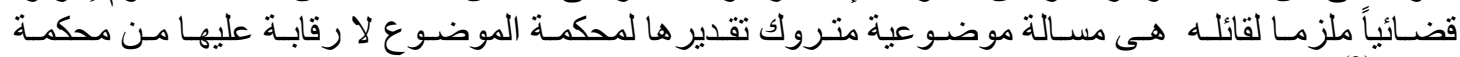
النقض (2).

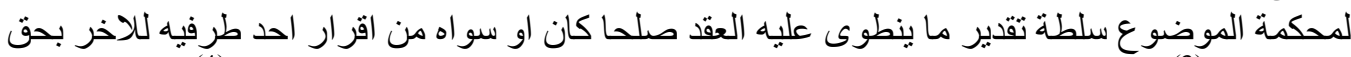

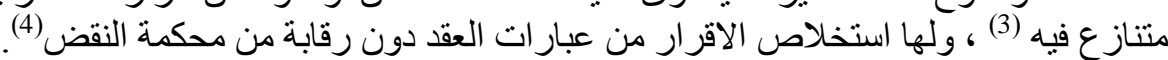

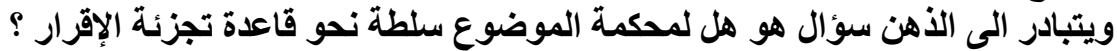

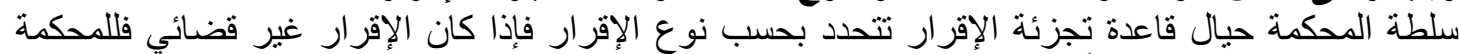

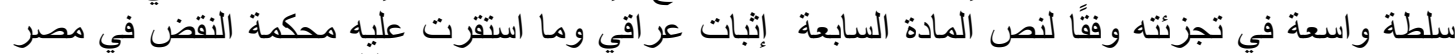

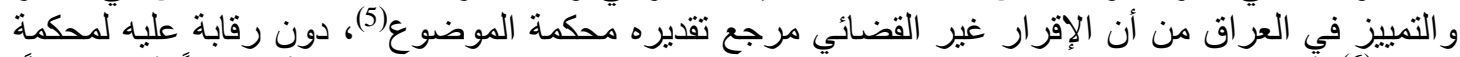

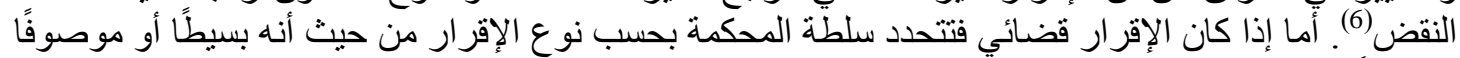

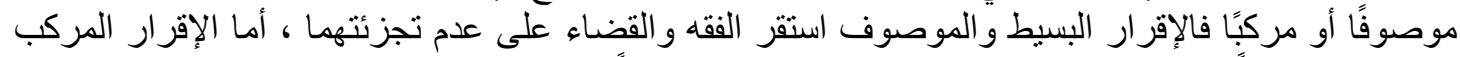

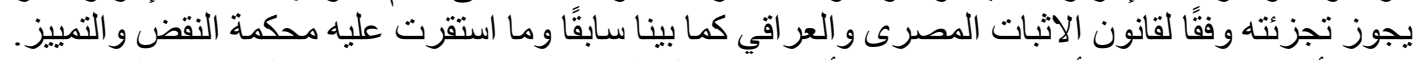

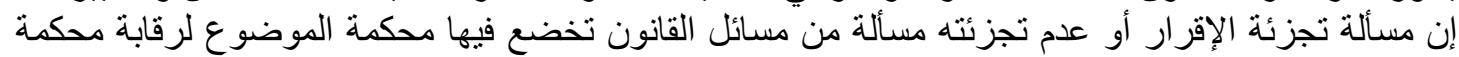

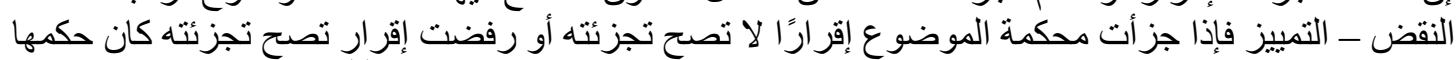

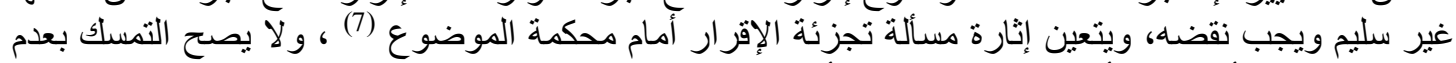

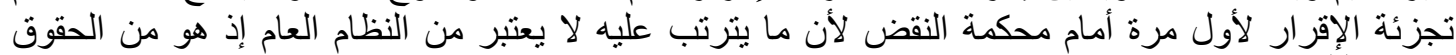
الخاصة:(8)

طعن 119 لسنة 24ق جلسة 1967/10/21مكتب فنى س 18 ص 584 ،د. عبدالودود يحي ، المرجع السابق ، ص

طعن 39 لسنة 1 ق جلسة 1932/5/19مجموعة ال 25 سنة ج1 ص34 ، د. د. عبدالودود يحي ، المرجع السابق ،

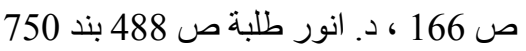

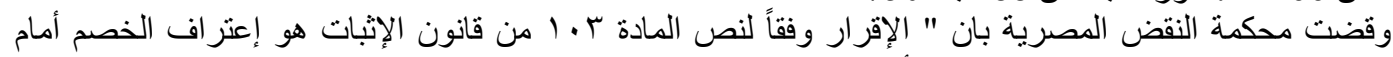

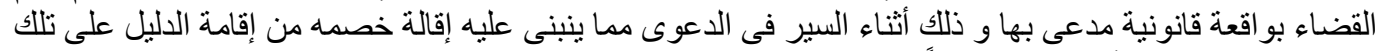

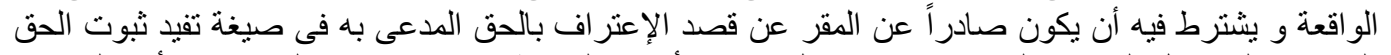

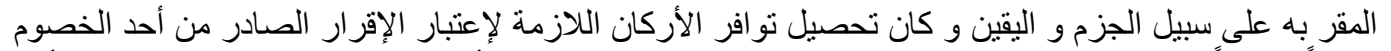

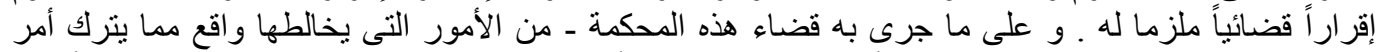

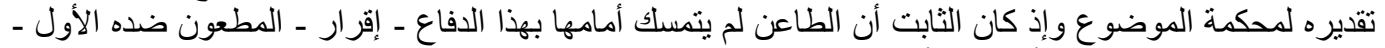

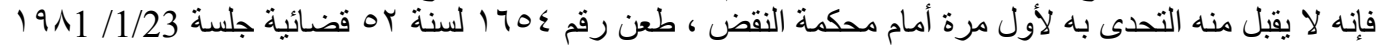

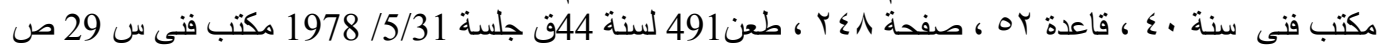

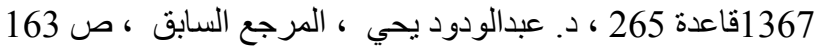

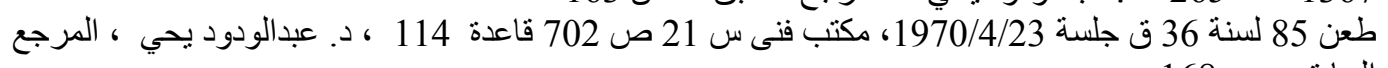

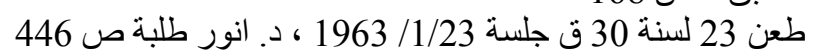

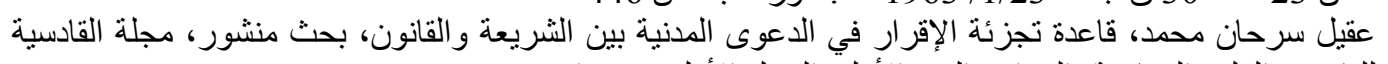

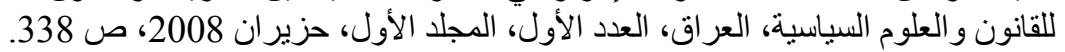

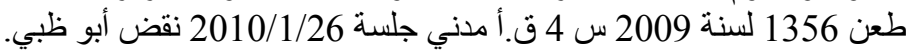

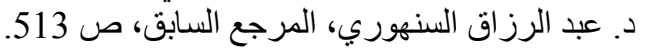

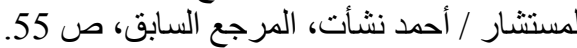




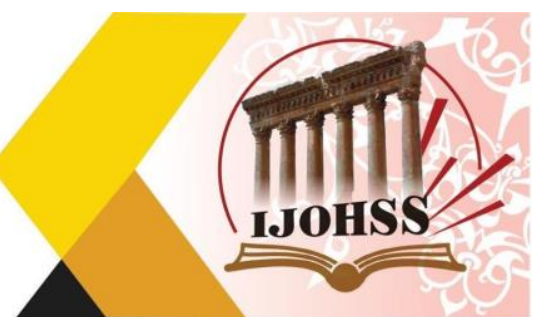

وقاعدة عدم تجزئة الاقر ار لا تحول دون سلطة القاضى فى تفسير الاقرار و واستخلاص نتائج قانونية منها مغايرة

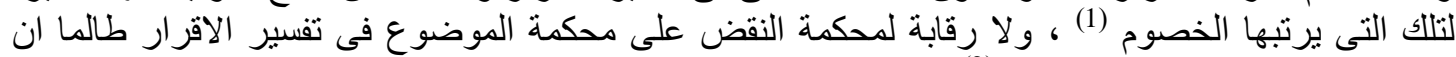

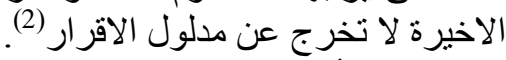
و لا تعنبر الأقو ال المنسوبة إلى الخصم تعتبر إقرار أ منه أو لا تعتبر كذلك مسألة قانونية تخضع لرقابة محكمة النقض (3). سلطة محكمة الموضوع في تفسير الإقرار

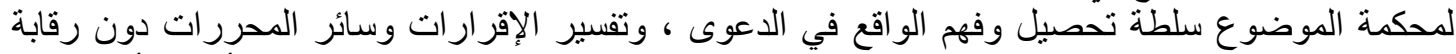

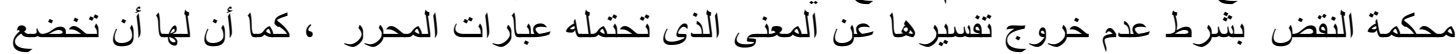

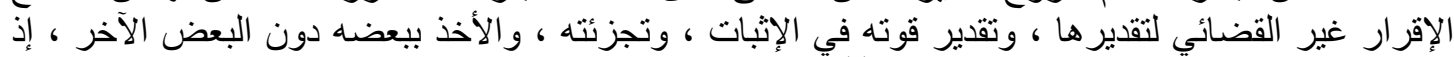

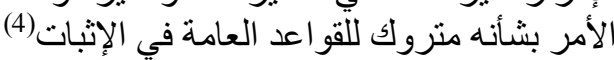

الخاتمة

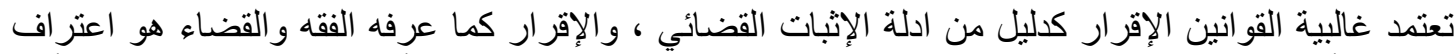

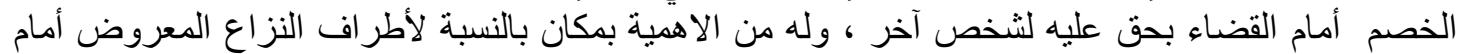

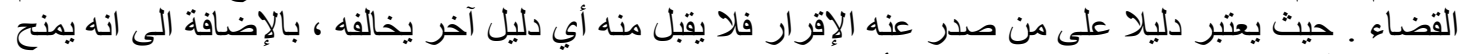

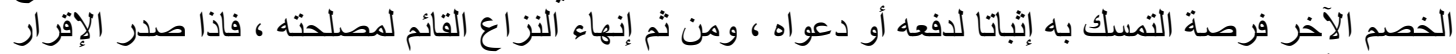

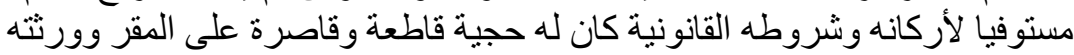

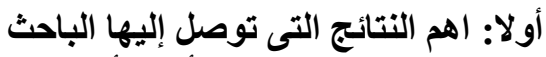

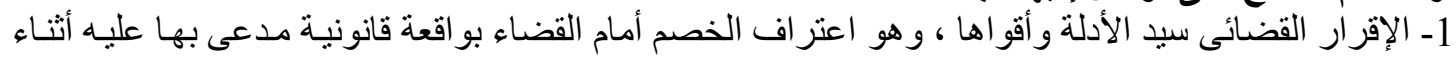

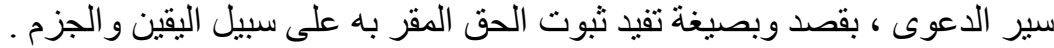

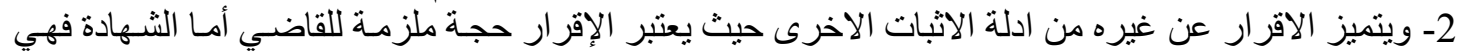

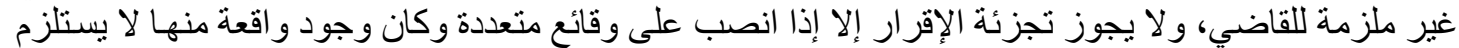

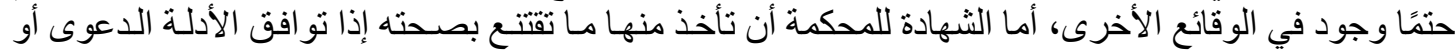

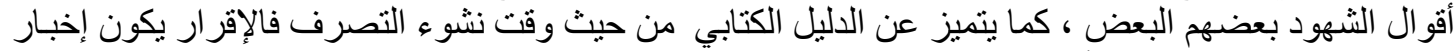

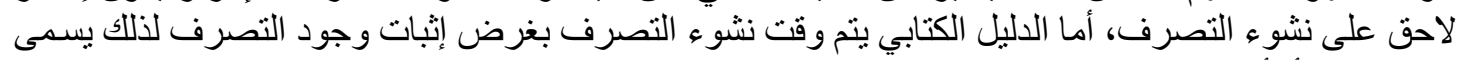

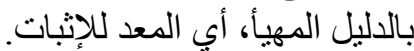

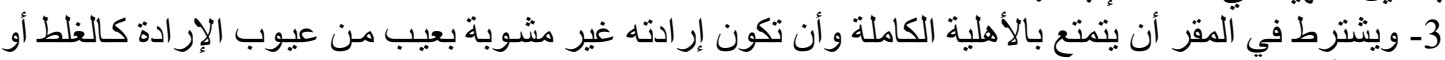

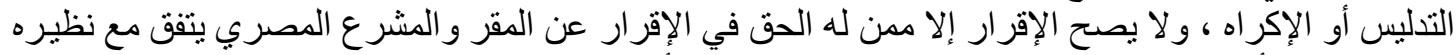

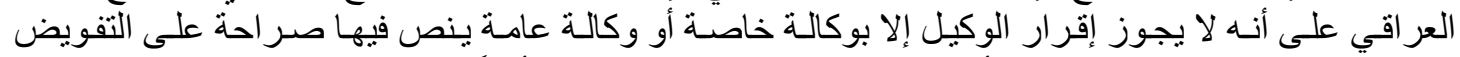

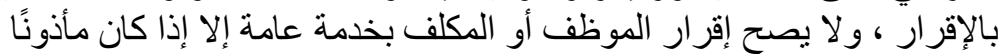

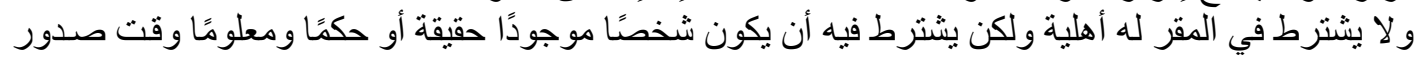

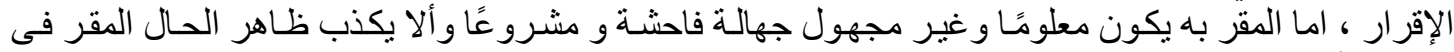

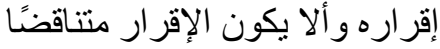

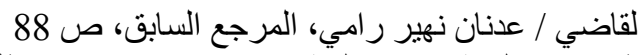

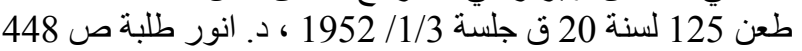

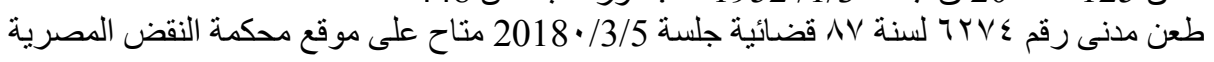
https://www.cc.gov.eg/civil judgments

طعن رقم ع T9V لسنة VI VIائية الدوائر التجارية - جلسة 2007/6/14 متاح على موقع محكمة النقض المصرية https://www.cc.gov.eg/judgment_single?id=111315683\&ja=242225 


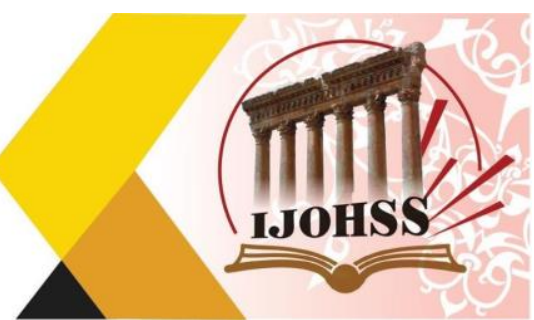

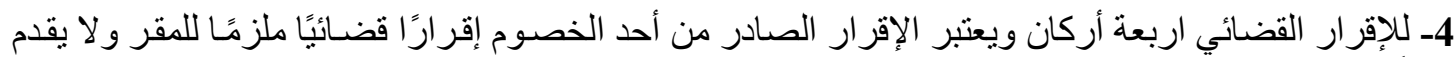

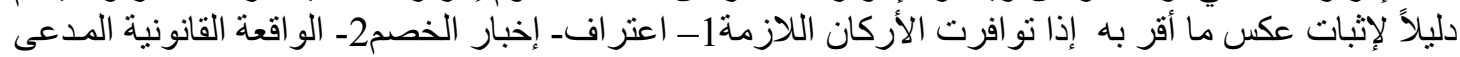

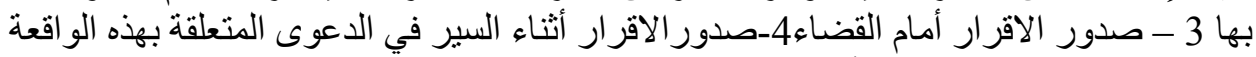

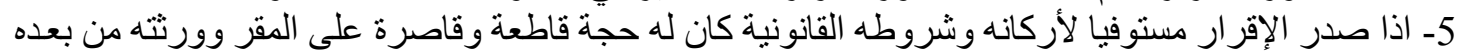

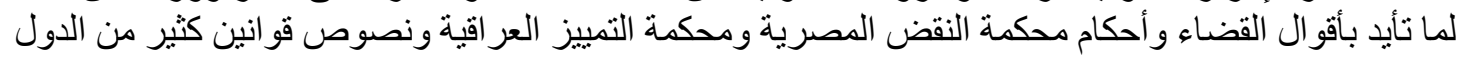

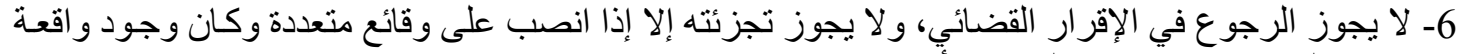

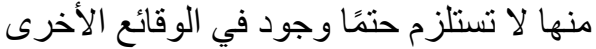

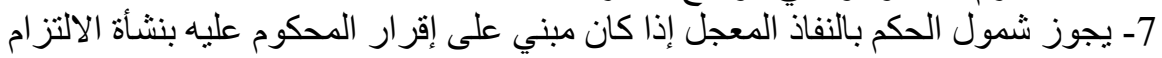

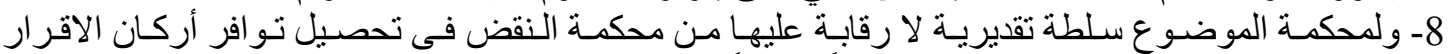

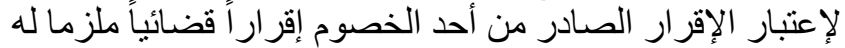

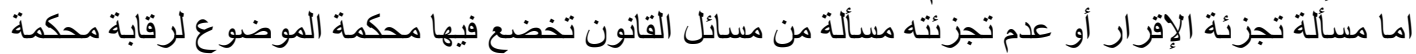

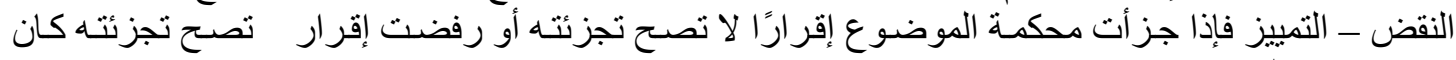
حكمها غير سليم ويجب نقضنه.

ثانيا : التوصيات

ـ تعديل المادة 1/104 من قانونيات الإن الإثبات المصري لتكون كما يلي: المادة 104: الإقرار حجة قاطعة وقاصرة

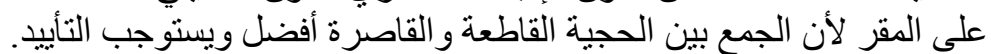

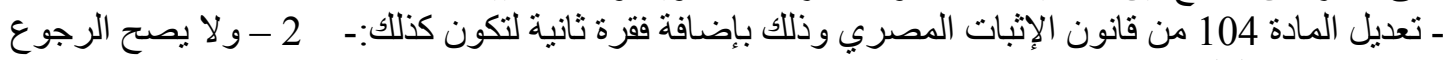
عن الإقرار إلا لغلط جو هري.

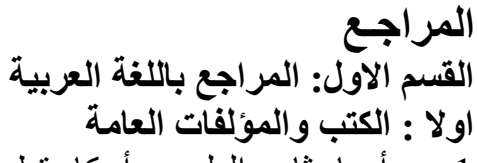

1. د. أجياد ثامر الدليمي، أحكام قطع السير في الدعوى المدنية، دار الجامعة الجديدة، 2015 2. د. أجياد ثامر الدليمي، سقوط الدعوى الددنية وانقضائها بمضي الدية المدة، المركز العربي للنشر، ط1، سنة 2018

3. د. أحمد أبو الوفا، التعليق على قانون الإثبات، منشأة المعارف، الإسكندرية، سنة 2000

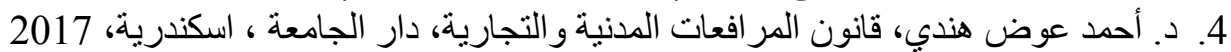

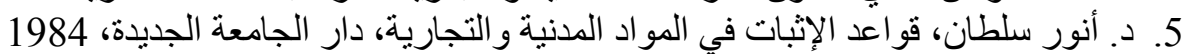

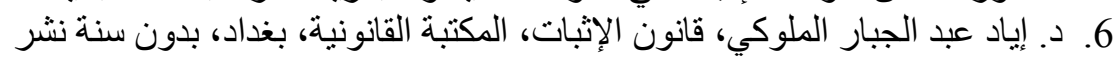

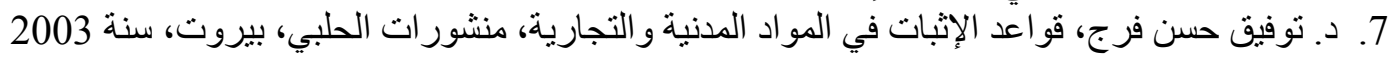

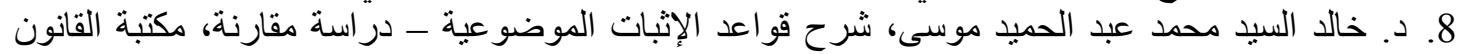

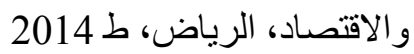
9. د. خالد السيد محمد عبد الحميد موسى، شرح قو اعد الإثبات الموضوعية، مكتبة القانون والاقتصاد، الرياض،

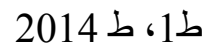

10. د. سليمان مرقس، الإقرار و اليمين، بدور دار نشر ، 1970

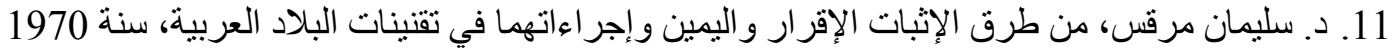

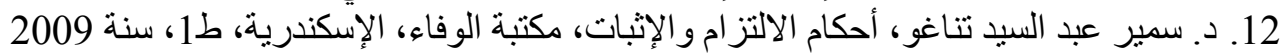

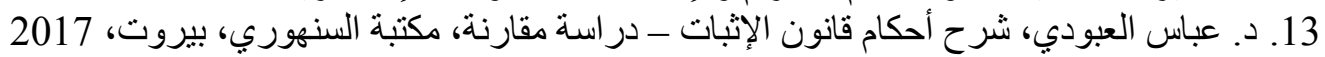

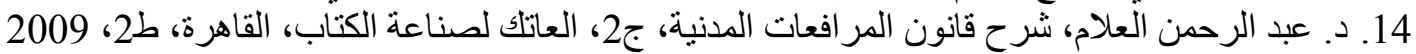

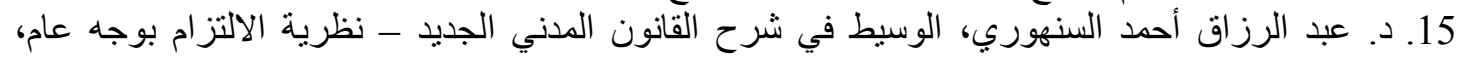

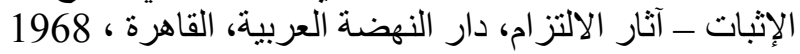

16. د. عبد المنعم فرج الصندات دار الإثبات في المو اد الددنية، ط2، مطبعة مصطفى الحلبي، القاهرة، سنة 1954 


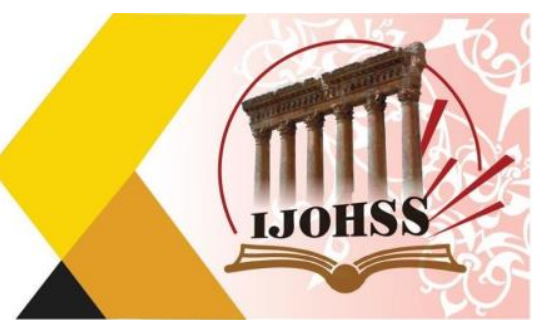

17. د. عبدالودود يحى ، الموسو عة العلمية لاحكام محكمة النقض ،ج2، بدون بدون دار نشر سنة 1984

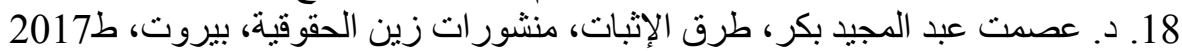

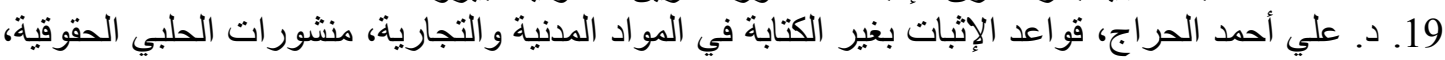
بيروت، عام 2010 20. د. لاشثين محمد يونس الغاياتي، دور الثهادة في الإثبات، بحث منشور في مجلة كلية الثريعة والقانون،

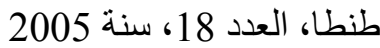
21. د. محمد بن بر الك الفوزان، الوسيط في نظام المرافعات الثرعية السعودي، مكتبة القانون والاقتصاد، ج1، .2009 b 22. د. محمد حسن قاسم، قانون الإثبات في المو اد المدنية و التجارية، منشور رات الحلبي الحقوقية، بيروت، بدون سنة نشر در دمر

23. د. محمد شفيق العاني، أصول المر افعات و الصكوك في القضاء الثرعي، جروب، بغداد، 1957

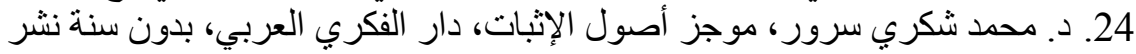

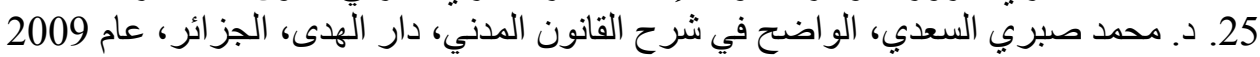

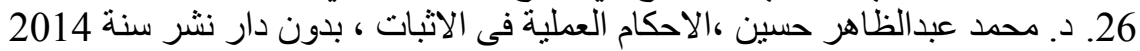

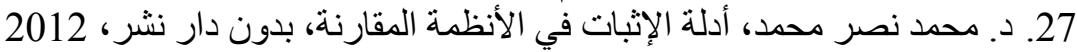

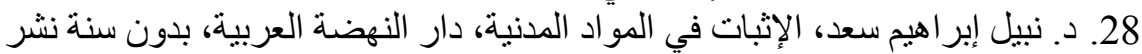

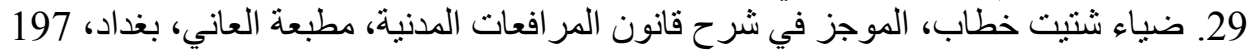

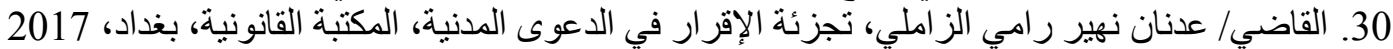

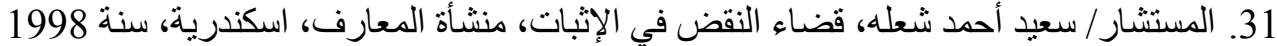

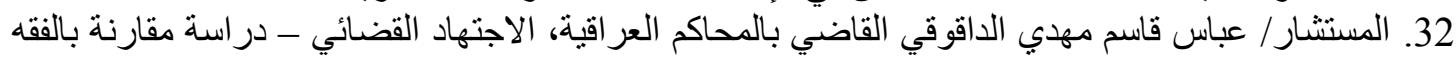

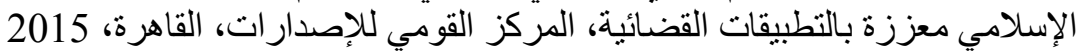

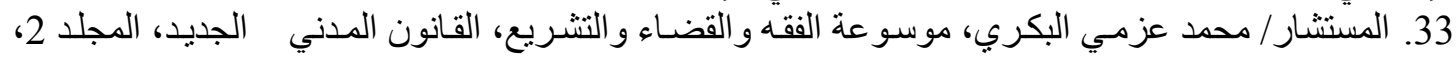
مصار الالتز ام، دار محمود للنشر النئري

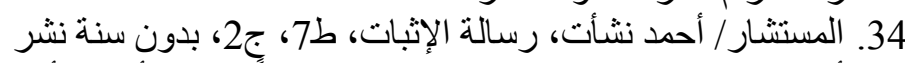

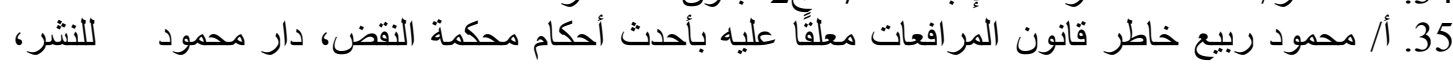

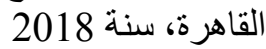
تانياً: رسائل الاكتوراه د. إبراهيم رحمد الهئ السعدي أحمد الثريعي، الصفة في الدفاع أمام القضاء المدني، رسالة دكتور اه، جامعة عين

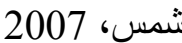
ثالثاً: رسائل الماجستير

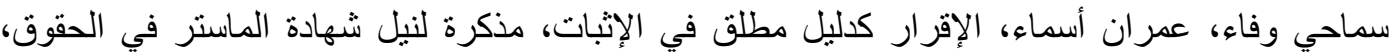

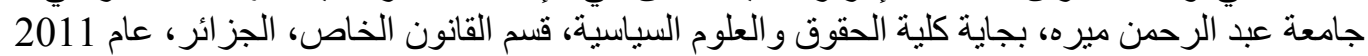
رابعاً: البحوث القدانونية

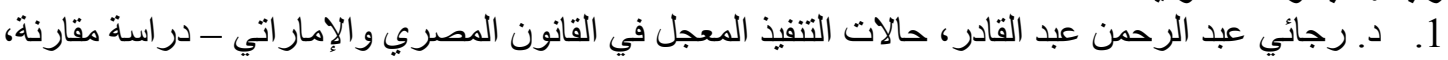

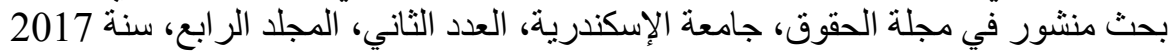

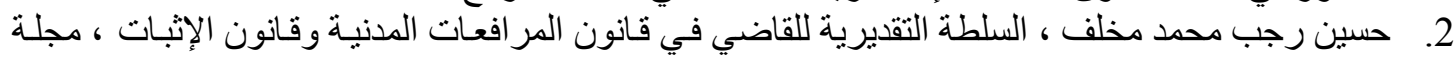

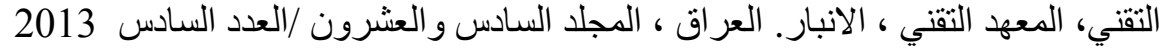

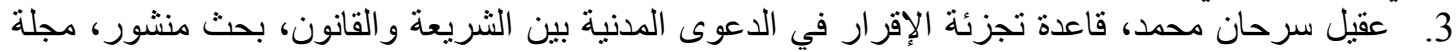

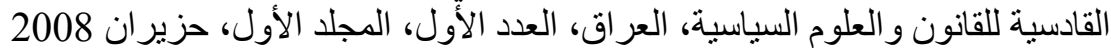
خامساً : القوانين واحكام المحاكم والمواقع الإلكترونية العزية

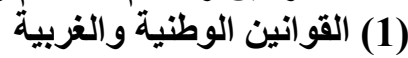

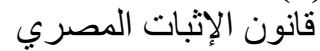
قانون الإثبات العر اقي رقم 107 لسنة 1979 المعدل بالقانون رقم 46 لسنة 2000. 
أغسطس 2020

(14) العدد)

ISSN: $2415-4822$

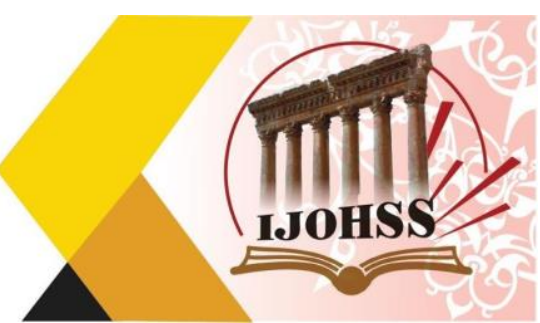

قانون الإثبات الإمار اتي المعدل بالقانون رقم 16 لسنة 2016.

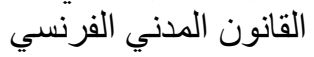

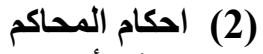

مجمو عة الأستاذ إبر اهيم المشاهدي، المبادئ القانونية في قضاء محكمة التمبيز - قسم القانون المدني، مركز

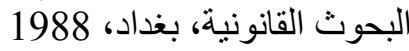
(3) (المنتديات القانونية موقع محكمة النقض المصرية. موقع بو ابة مصر للقانون و القضاء الموقع الالكتروني للسلطة القضائية العر اقية

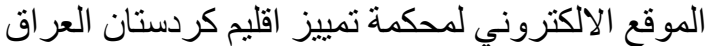

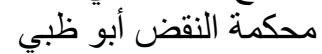
(4) (4) (الكتب الاجنبية موسو عة دالوز ، القانون المدنى الفرنسى باللغة العربية ، جامعة القديس يوسف ، بيروت المواقع الاكترونية

http://www.laweg.net/Default.aspx?action=HP https://www.cc.gov.eg/civil_judgments https://www.cc.gov.eg/judgment_single?id=111315683\&ja $=242225$ https://www.iasj.net/iasj?func=fulltext\&aId=136390 www.hjc.iq www.iraqja.org www.qanoun.iraqja.iq 


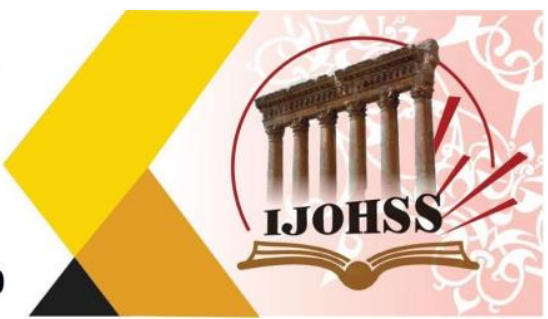

\section{References}

First: books and general literature

1. Dr. Ajyad Thamer Al-Dulaimi, Rulings of cutting traffic in a civil lawsuit, New University House, 2015

2. Dr. Ajyad Thamer Al-Dulaimi, Civil case dropped and expired, period, Arab Center for Publishing, 1st edition, year 2018

3. Dr. Ahmad Abu Al-Wafa, Commentary on the Evidence Law, Establishment of Knowledge, Alexandria, 2000

4. Dr. Ahmed Awad Hindi, Civil and Commercial Procedure Law, University House, Alexandria, 2017

5. D. Anwar Sultan, Evidence Rules for Civil and Commercial Articles, New University House, 1984

6. Dr. Iyad Abdul-Jabbar al-Muluki, Law of Evidence, Legal Library, Baghdad, without publication year

7. Dr. Tawfiq Hassan Faraj, Evidence Rules in Civil and Commercial Articles, AlHalabi Publications, Beirut, 2003

8. D. Khaled al-Sayyid Muhammad Abd al-Hamid Musa, Explanation of Substantive Evidence Rules - A Comparative Study, Library of Law and Economics, Riyadh, 2014 edition

9. Dr. Khaled al-Sayyid Muhammad Abd al-Hamid Musa, Explanation of Substantive Evidence Bases, Library of Law and Economics, Riyadh, 1st edition, 1st edition 2014

10. Dr. Solomon Marcus, acknowledgment and oath, the role of a publishing house, 1970

11. Dr. Solomon Marcus, one of the methods of proof is acknowledgment and oath and their procedures in the standards of Arab countries, in 1970

12. Dr. Samir Abdel-Sayed Tanago, Obligation and Evidence Provisions, Al-Wafa Library, Alexandria, 1st edition, 2009

13. Dr. Abbas Al-Aboudi, Explanation of Provisions of the Evidence Law - A Comparative Study, Al-Sinhouri Library, Beirut, 2017

14. Dr. Abd al-Rahman al-Allam, Explanation of the Civil Procedure Law, Part 2, AlAtak for Book Production, Cairo, 2nd edition, 2009

15 D. Abdul-Razzaq Ahmed Al-Senhouri, mediator in explaining the new civil law the theory of commitment in general, evidence - effects of compliance, Dar Al-Nahda Al-Arabiya, Cairo, 1968

16. Dr. Abdel Moneim Faraj Al-Sadah, Evidence in Civil Articles, 2nd edition, Mustafa Al-Halabi Press, Cairo, 1954

17. Dr. Abdel-Wadood Yahya, Scientific Encyclopedia of the Court of Cassation rulings, part 2, without a publishing house in 1984

18. Dr. Esmat Abdel-Majid Bakr, Methods of Evidence, Zain Juridical Publications, Beirut, 2017 edition

19 d. Ali Ahmad Al-Haraj, Rules of Evidence other than Writing in Civil and Commercial Articles, Al-Halabi Human Rights Publications, Beirut, 2010 


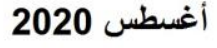

(14) العدد)

Volume (14) August 2020

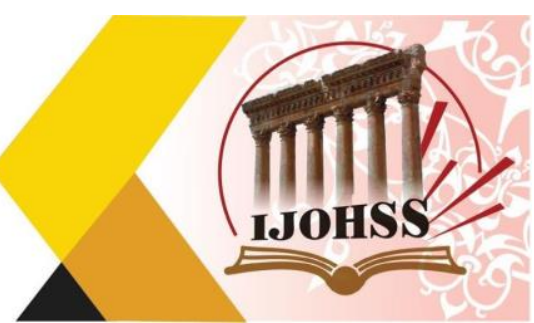

20. Dr. Lasheen Muhammad Yunus al-Ghayati, The Role of Certification in Evidence, a research published in the Journal of the College of Sharia and Law, Tanta, No. 18, 2005

21. Dr. Mohammed bin Barak Al-Fawzan, Mediator in the Saudi Shari'a Procedure System, Law and Economy Library, Part 1, i 2009

22. Dr. Muhammad Hasan Qasim, Evidence Law in Civil and Commercial Articles, Al-Halabi Human Rights Publications, Beirut, without a year of publication

23. Dr. Muhammad Shafiq Al-Ani, Principles of Pleadings and Sukuk in Sharia Judiciary, Part 1, Baghdad, 1957

24. Dr. Muhammad Shukri Srour, Summary of Fundamentals of Evidence, Dar AlFikry Al-Arabi, without publication year

25. Dr. Muhammad Sabri Al-Saadi, clear in explaining the civil law, Dar Al-Hoda, Algeria, 2009

26. Dr. Muhammad Abdul-Zahir Hussein, practical provisions in evidence, without a publishing house in 2014

27. Dr. Muhammad Nasr Muhammad, Evidence in Comparative Systems, without publishing house, 2012

28. Dr. Nabil Ibrahim Saad, Evidence in Civil Articles, Arab Renaissance House, without publication year

29. Dhia Shtit Khattab, The Abstract in Explaining the Civil Procedure Law, Al-Ani Press, Baghdad, 197

30. Judge / Adnan Nahir Rami Al-Zamili, Fragmentation of the Declaration in the Civil Case, Legal Library, Baghdad, 2017

31. Counselor / Saeed Ahmed Shu 'lah, Court of Cassation of Evidence, Establishment of Knowledge, Alexandria, in the year 1998

32. Counselor / Abbas Qassem Mahdi Al-Daqiqi, Judge in Iraqi Courts, Jurisprudence

- A Comparative Study of Islamic Jurisprudence Enhanced by Judicial Applications, The National Center for Publications, Cairo, 2015.

33. Counselor / Mohamed Azmy El-Bakry, Encyclopedia of Jurisprudence, Jurisdiction and Legislation, New Civil Law, Volume 2, Masar al-Titham, Mahmoud Publishing House

34. Counselor / Ahmed Nashat, Evidence Letter, No. 7, Part 2, without publication year

35. A / Mahmoud Rabie Khater, Procedure Law, Commenting on it with the most recent rulings of the Court of Cassation, Mahmoud Publishing House, Cairo, 2018.

\section{Second: PhD theses}

Dr.. Ibrahim Muhammad Al-Saadi Ahmed Al-Shareei, Adjective in Defense before the Civil Judiciary, Ph.D., Ain Shams University, 2007 


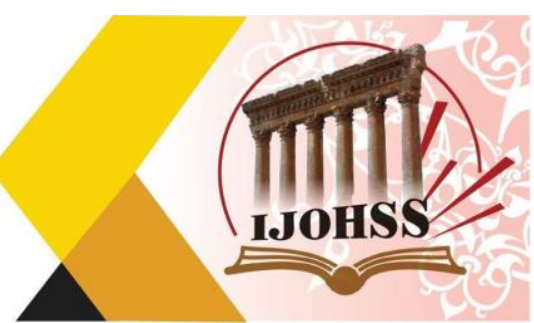

\section{Third: Master Theses}

Samahi Wafa, Imran Asma, Admission as absolute proof of proof, Memorandum for Masters Degree in Law, University of Abdel Rahman Mirah, Bejaia Faculty of Law and Political Science, Department of Private Law, Algeria, 2011

\section{Fourth: Legal research}

1. Dr. Rajaei Abdel-Rahman Abdel-Qader, Cases of Accelerated Implementation in Egyptian and Emirati Law - A Comparative Study, Research published in the Journal of Law, University of Alexandria, No. 2, Volume 4, 2017

2. Hussein Rajab Muhammad Mukhlif, Judge's Discretionary Authority in the Civil Procedure and Evidence Law, Technical Magazine, Technical Institute, Anbar. Iraq, Volume Twenty-Six / Sixth Issue 2013

3. Aqeel Sarhan Muhammad, The Rule of Fragmentation of the Declaration in the Civil Case between Sharia and Law, published research, Al-Qadisiyah Journal of Law and Political Science, Iraq, first issue, first volume, June 2008

\section{Fifth: Laws, court rulings and websites}

(1) National and Western laws

Egyptian Evidence Law

Iraqi Evidence Law No. 107 of 1979 amended by Law No. 46 of 2000.

UAE Proof Law amended by Law No. 16 of 2016.

French civil law

\section{(2) Court rulings}

Professor Ibrahim Al-Mashhadi, Legal Principles in the Court of Cassation - Civil Law Department, Center for Legal Research, Baghdad, 1988

(3) Legal Forums

Egyptian Court of Cassation website.

Egypt's website for law and justice

The website of the Iraqi judiciary

The website of the Iraqi Kurdistan Region Court of Cassation

Abu Dhabi Court of Cassation

\section{(4) Foreign books}

Dalouz Encyclopedia, French Civil Law in Arabic, Saint Joseph University, Beirut

(5) Websites

http://www.laweg.net/Default.aspx?action=HP

https://www.cc.gov.eg/civil_judgments

https://www.cc.gov.eg/judgment_single $? \mathrm{id}=111315683 \& \mathrm{da}=242225$

https://www.iasj.net/iasj?func=fulltext\&aId $=136390$

www.hjc.iq

www.iraqja.org

www.qanoun.iraqja.iq 